\author{
UNIVERSIDADE DE SÃO PAULO \\ FACULDADE DE FILOSOFIA, LETRAS E CIÊNCIAS HUMANAS \\ DEPARTAMENTO DE LINGUÍSTICA
}

CAMILA DOS SANTOS RIBEIRO

SEMIÓTICA E TENSIVIDADE:

O FAZER MISSIVO, SEUS DESDOBRAMENTOS TEÓRICOS E MODOS DE APLICAÇÃO

SÃO PAULO

2010 
CAMILA DOS SANTOS RIBEIRO

SEMIÓTICA E TENSIVIDADE:

\section{O FAZER MISSIVO, SEUS DESDOBRAMENTOS TEÓRICOS E MODOS DE APLICAÇÃO}

Dissertação apresentada ao Programa de PósGraduação em Semiótica e Linguística Geral do Departamento de Linguística da Faculdade de Filosofia, Letras e Ciências Humanas da Universidade de São Paulo, para obtenção do título de Mestre em Linguística

Área de concentração: Semiótica e Linguística Geral

Orientador: Prof. Dr. Ivã Carlos Lopes

SÃO PAULO

2010 
Nome: RIBEIRO, Camila dos Santos

Título: Semiótica e tensividade: o fazer missivo, seus desdobramentos teóricos e modos de aplicação

Dissertação apresentada ao Programa de PósGraduação em Semiótica e Linguística Geral do Departamento de Linguística da Faculdade de Filosofia, Letras e Ciências Humanas da Universidade de São Paulo, para obtenção do título de Mestre em Linguística

Aprovado em: / 05 / 2010

Banca Examinadora

Prof. Dr. Ivã Carlos Lopes

Instituição: Universidade de São Paulo (USP)

Julgamento:

Assinatura

Prof. Dr. Luiz Augusto de Moraes Tatit Instituição: Universidade de São Paulo (USP) Julgamento: Assinatura:

Prof. Dr. Jean Cristtus Portela Instituição: Universidade Estadual Paulista Júlio de Mesquita Filho (UNESP) Julgamento: Assinatura: 
Ao meu orientador, Prof. Dr. Ivã Carlos Lopes, com respeito, orgulho e gratidão, por há sete anos ter me acolhido e me guiado nesse longo caminho que há tanto sonhei em trilhar. 


\section{AGRADECIMENTOS}

À professora Denise Aparecida Masson Maiolino, primeira doutora em linguística que conheci, há dez anos, por me fazer acreditar que meu sonho era possível.

Ao meu orientador, Prof. Dr. Ivã Carlos Lopes, pela oportunidade e apoio, desde a minha pesquisa de Iniciação Científica.

Ao Prof. Dr. Antonio Vicente Seraphim Pietroforte, pela chance de conhecer tantos autores brasileiros contemporâneos de altíssima qualidade, dois deles hoje objeto de minha pesquisa, e pelos anos de incentivo.

Aos meus inestimáveis amigos de graduação, Carla Aurora, Débora Cardoso, Alessandra Aronne, Eleonora Ribeiro, Maria Paula Roncaglia e Regiane Varela, por terem compartilhado as alegrias e aflições do bachalerado em Letras.

Aos meus queridos e sinceros amigos do GES-USP, em especial, Carolina Lindenberg Lemos, sempre tão cheia de perguntas e opiniões; Mariana Luz Pessoa de Barros, pela leveza e serenidade; Juliana di Fiori Pondian,amiga querida presente desde minha primeira reunião de iniciação científica, inabalável fonte de otimismo e determinação; Dayane Celestino de Almeida, por sempre ser aquela a me ajudar com as mais assustadoras burocracias e, acima de tudo, por compartilharmos desde momentos de alegria e satisfação até aqueles de absoluta frustação e desesperança; Carolina Tomasi, por ter entrado em minha vida de sopetão, de 
braços abertos e sorrisos inesgotáveis, presenteando-me com sua amizade e apoio sem limites.

À Profa. Dra. Norma Discini, pela alegria que traz ao nosso grupo, por suas aulas inspiradoras, e pela leitura atenta do meu relatório de qualificação.

Ao Prof. Dr. Luiz Augusto de Moraes Tatit, por ter me fornecido um dos textos essenciais para minha pesquisa, pela leitura inestimável de meu relatório de qualificação e por fazer parte de minha banca de defesa.

Ao Prof. Dr. Waldir Beividas, por ter assumido minha orientação quando da ausência do professor Ivã.

Ao Prof. Dr. Jean Cristtus Portela, pesquisador que passei a admirar, por sua participação em minha banca de defesa.

Ao Departamento de Linguística da Faculdade de Filosofia, Letras e Ciências Humanas da Universidade de São Paulo, pela oportunidade da realização da PósGraduação em um programa de excelência.

Ao Conselho Nacional de Desenvolvimento Científico e Tecnológico (CNPq), pela bolsa concedida para a realização deste trabalho.

E, finalmente, aos escritores Delmo Montenegro e Valêncio Xavier (em memória), por seus textos intrigantes que reanimam minha paixão pela literatura. 
As coisas têm peso, massa, volume, tamanho, tempo, forma, cor, posição, textura, duração, intensidade, cheiro, valor, consistência, profundidade, contorno, temperatura, função, aparência, preço, destino, idade, sentido.

As coisas não têm paz.

Arnaldo Antunes 


\section{RESUMO}

RIBEIRO, Camila dos Santos. Semiótica e tensividade: o fazer missivo, seus desdobramentos teóricos e modos de aplicação. 2010. 136 f. Dissertação (Mestrado) - Faculdade de Filosofia, Letras e Ciências Humanas, Universidade de São Paulo, 2010.

Recentemente, a semiótica greimasiana vem assistindo ao desenvolvimento de uma nova posição quanto à abordagem do universo de sentido. A chamada semiótica tensiva, desenvolvida principalmente por Claude Zilberberg, traz à baila a discussão de alguns problemas não explorados ou não esclarecidos pelo modelo de Greimas como, por exemplo, a possibilidade da análise dos conteúdos sensíveis ao lado dos conteúdos inteligíveis - esses já contemplados pelo percurso gerativo do sentido canônico; ou ainda o movimento de transvalorização de um nível a outro. Em meio a tamanha renovação do modelo greimasiano, Zilberberg publica, em 1986, o texto "Pour introduire le faire missif', contido na revista de estudos semióticos RSSI. Logo de início, Zilberberg nos apresenta o conceito de missividade como uma tentativa de dar à sintaxe seu espaço merecido na teoria semiótica, de modo que aquela não mais fosse vista apenas como mobilizadora da semântica e sim como possuidora de uma atividade que the é própria. A missividade é então dividida em dois fazeres básicos: um remissivo, o qual promoveria a parada, e um emissivo, o qual instituiria a parada da parada. É ao encontro do conceito de missividade introduzido por Claude Zilberberg e ao seu posterior caminhar na semiótica tensiva que nossa pesquisa se apresenta. Em paralelo, nos utilizaremos de textos literários de dois autores contemporâneos brasileiros - Delmo Montenegro e Valêncio Xavier - para a aplicação prática do fazer missivo e outros conceitos tensivos. Ao longo de 
nossa dissertação caminharemos, pois, em duas direções: a releitura e síntese do desenvolvimento do conceito de missividade no modelo tensivo e a extensão e vantagem de sua aplicação em textos literários.

Palavras-chave: Semiótica. Tensividade. Literatura brasileira contemporânea. Linguística. 
ABSTRACT

RIBEIRO, Camila dos Santos. Semiotics and the tensive model: le faire missif, its theoretical development and application methods. 2010. $136 \mathrm{f}$. Dissertação (Mestrado) - Faculdade de Filosofia, Letras e Ciências Humanas, Universidade de São Paulo, 2010.

Recently, Greimasian semiotics has seen the development of a new position regarding the approach of the universe of meaning. The so-called tensive semiotics, developed mainly by Claude Zilberberg, brings forth the discussion on some issues neither explored nor clarified by Greimas's model such as, for instance, the possibility of analyzing sensitive contents along with intelligible contents - already contemplated by the canonical generative trajectory of meaning; or still the movement of transvaluation from one level to another. Amid such renewal of the Greimasian model, Zilberberg publishes, in 1986, the article "Pour introduire le faire missif" situated in RSSI magazine. Right from the beginning, Zilberberg presents us the concept of "le faire missif" as an attempt to give syntax its deserved space in semiotics, so that the former would not be seen simply as a mobilizer of semantics, but possessing its own activity. Such concept ("le faire missif") is then divided into two basic activities: a remissive ("rémissif') one, which would promote the continuity of the process, and an emissive ("émissif") one, which would promote the halt of the process. Our research currently moves towards the concept of "le faire missif" introduced by Claude Zilberberg and its subsequent path in tensive semiotics. Meanwhile, we will make use of literary texts by two contemporary Brazilian writers Delmo Montenegro and Valêncio Xavier - for the practical application of the missive 
activity and other tensive concepts. During our dissertation we will then move in two directions: re-reading and synthesizing the development of the concept of "le faire missif" in the tensive model and the extents and advantages of its application in literary texts.

Keywords: Semiotics. Tensive Model. Brazilian contemporary literature. Linguistics. 


\section{LISTA DE FIGURAS}

Figura 1 - Gráfico do "desenvolvimento, descendência e alternância" .26

Figura 2 - Quadro "Tensif/Tensal”

Figura 3 - Quadro “Directif/Directal”.

Figura 4 - Quadro "Disjonctif/Disjonctal” .28

Figura 5 - Quadro “Jonctif/Jonctal” .28

Figura 6 - Estrutura do fazer missivo .34

Figura 7 - Fazer remissivo e fazer emissivo .35

Figura 8 - Quadro de cadastro modal segundo os fazeres emissivo e remissivo ....37

Figura 9 - Gráfico do pervir e sobrevir .43

Figura 10 - Quadro do exercício e do acontecimento 44

Figura 11 - Quadro das modalidades segundo a missividade conjugado ao acontecimento e exercício

Figura 12 - Quadro das isotopias de "Ciao cadáver" .63

Figura 13 - Cena de Transubstanciação, de Lourenço Mutarelli .64

Figura 14 - Gráfico das isotopias de "Ciao cadáver" .68

Figura 15 - página 13 de Maciste no Inferno (raconto) .76

Figura 16 - página 1 de Maciste no Inferno (raconto) .78

Figura 17 - página 5 de Maciste no Inferno (raconto) .79

Figura 18 - página 13 de Maciste no Inferno (raconto) 80

Figura 19 - página 17 de Maciste no Inferno (raconto) .81

Figura 20 - página 21 de Maciste no Inferno (raconto) .82

Figura 21 - página 23 de Maciste no Inferno (raconto) 82 
Figura 22 - página 25 de Maciste no Inferno (raconto) ….................................... 83

Figura 23 - página 27 de Maciste no Inferno (raconto) ........................................84

Figura 24 - página 29 de Maciste no Inferno (raconto) ..........................................84

Figura 25 - página 31 de Maciste no Inferno (raconto) .........................................85

Figura 26 - página 33 de Maciste no Inferno (raconto) .........................................86

Figura 27 - página 35 de Maciste no Inferno (raconto) .........................................87

Figura 28 - página 37 de Maciste no Inferno (raconto) ..........................................88

Figura 29 - página 39 de Maciste no Inferno (raconto) ........................................89

Figura 30 - página 41 de Maciste no Inferno (raconto) .........................................90

Figura 31 - página 43 de Maciste no Inferno (raconto) .........................................91

Figura 32 - página 45 de Maciste no Inferno (raconto) ...........................................92

Figura 33 - página 47 de Maciste no Inferno (raconto) .........................................92

Figura 34 - página 49 de Maciste no Inferno (raconto) .........................................93

Figura 35 - página 51 de Maciste no Inferno (raconto) ..........................................94

Figura 36 - página 53 de Maciste no Inferno (raconto) .............................................94 


\section{SUMÁRIO}

INTRODUÇÃO

1. INTRODUZINDO O FAZER MISSIVO: GERATIVIDADE E TRANSVALORIZAÇÃO........................23

2. O FAZER MISSIVO: CONCEITUAÇÃO ........................................................................

3. A RESSONÂNCIA DA SURPRESA: O ACONTECIMENTO E A MISSIVIDADE ..........................40

4. ANÁliSe de “Ciao CadÁver”, de Delmo Montenegro ….........................................49

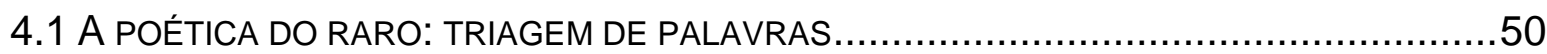

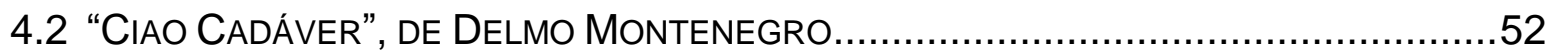

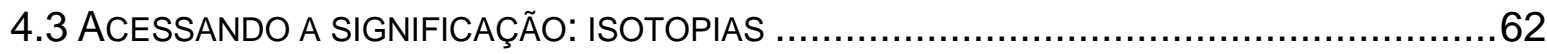

4.4 O PERCURSO DE UMA NÉKUIA: MOMENTO DE REMISSIVIDADE..............................67

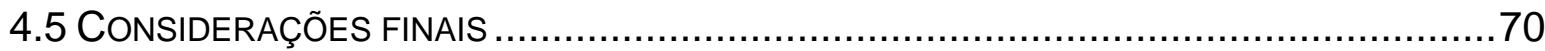

5. ANÁlise de MACISTE no INFERno (RACONTO), DE VALÊNCIO XAVIER ...........................72

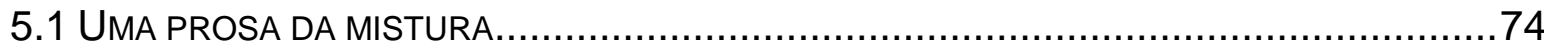

5.2 MACISTE NO INFERNO (RACONTO): BREVE RESUMO ........................................

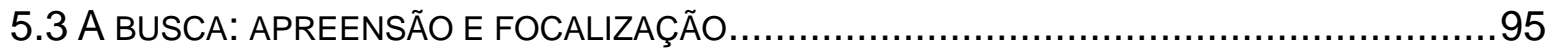

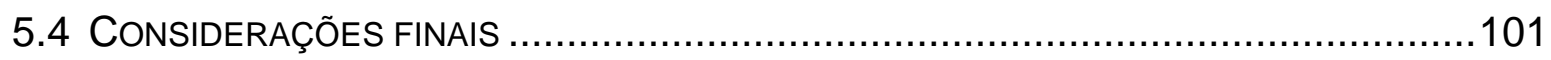

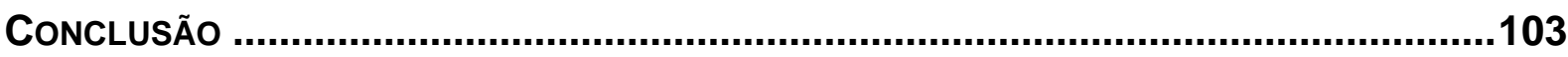

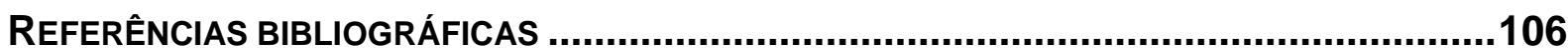

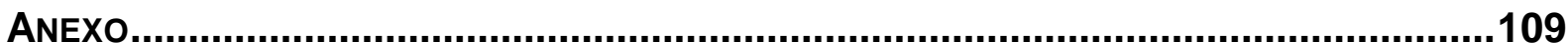

ANEXo A - MACISTE No INFERNo (RACONTO), DE VALÊNCIO XAVIER ...........................109 


\section{INTRODUÇÃO}

A linha semiótica por nós adotada é a da chamada Escola de Paris. No entanto, daremos ênfase a sua configuração mais recente, constituída pelo modelo tensivo desenvolvido, principalmente, por Claude Zilberberg.

Apoiando-se em estudos anteriores de grandes nomes das ciências humanas, tais como Vladmir Propp, Lévi-Strauss, Roman Jakobson, Louis Hjelmslev e Ferdinand de Saussure, a semiótica greimasiana tradicional surge como tentativa de construção de uma ciência geral da significação.

Assim, mais do que explicar o sentido de um texto, a semiótica busca explicitar seu processo de significação. Ainda que entendendo o sistema semiótico como a articulação entre o plano do conteúdo e o plano da expressão, o modelo greimasiano surge, de início, apenas com a solução descritiva do que Louis Hjelmslev conceitua como a forma do conteúdo. Para isso, propõe-se um simulacro metodológico chamado percurso gerativo do sentido - solução vertical encontrada para sistematizar o processo de significação dos textos.

Além da clara alusão terminológica (e apenas isso) às teorias de N. Chomsky, o percurso é chamado de gerativo porque mostra como o sentido é gerado a partir de estruturas muito simples e abstratas as quais vão ganhando complexidade e concretude conforme são enriquecidas em patamares mais superficiais.

Resumidamente, o percurso é composto de três níveis os quais, imbricados, acabam por dar sentido ao texto. O primeiro nível (mais geral e abstrato) é o nível fundamental - ou profundo - e nele a significação apresenta-se como oposição 
semântica sistematizada pela sintaxe do quadrado semiótico e sensibilizada pelas categorias fóricas. No segundo nível, o narrativo, organiza-se a narrativa do ponto de vista do sujeito modal e de suas relações juntivas com o objeto de valor e, por fim, no último nível (mais específico e concreto), o discursivo, a organização sêmionarrativa torna-se discurso em virtude dos procedimentos de temporalização, espacialização, actorialização, tematização e figurativização.

Por mais que aparente concretude, o nível discursivo ainda faz parte do plano do conteúdo e carece, portanto, de atualização no plano da expressão. Essa expressão pode ser de natureza verbal (como na literatura), não verbal (pintura, escultura, música etc.) ou sincrética - em que há a concomitância tanto de elementos verbais quanto não verbais (como nas histórias em quadrinhos ou no cinema).

No entanto, um simulacro metodológico para o estudo do plano da expressão tão organizado como o sugerido para o plano do conteúdo nunca chegou a ser desenvolvido de modo satisfatório, tornando o modelo semiótico bastante frágil no que diz respeito, principalmente, ao estudo de textos não verbais.

O fraco poder de análise de textos não verbais é apenas uma das lacunas do modelo greimasiano. Outro fato obscuro para a semiótica de Greimas era a passagem e transformação de conteúdos de um nível a outro. Com um modelo tão segmentado como o percurso gerativo do sentido, essa passagem se tornava brusca e inexplicável. O próprio quadrado semiótico, entendido como a sintaxe do nível fundamental, não explicava as gradações entre os termos simples.

No nível fundamental, surgia ainda mais um problema: como poderia sua semântica, pertencente ao nível que se pretendia mais abstrato do percurso, ser 
articulada por meio de universais semânticos tão concretos como vida vs. morte, natureza vs. cultura etc. ? Tais questionamentos, como o próprio Greimas comenta no "Avant-propos" do segundo volume do Dicionário de semiótica', acaba por gerar uma certa atratividade dos pesquisadores pelo nível profundo, provocando um verdadeiro congestionamento conceitual em um nível do modelo que, por princípio, deveria ser o mais sumário e conciso de todos.

Haveria, ainda, no caminho da semiótica greimasiana, a especulação sobre as paixões do sujeito semiótico. A necessidade de estudo dos conteúdos sensíveis se mostrava cada vez mais imperativa na medida em que apenas os conteúdos inteligíveis já não eram capazes de explicar como, por exemplo, um sujeito plenamente competente e manipulado (dotado das modalidades do querer/deverfazer e poder/saber-fazer) não realizava sua performance.

Embora Greimas, ao longo de sua vida, tenha conduzido o desenvolvimento da teoria semiótica mais interessado em construir uma metodologia de operacionalização solidária às ciências humanas e sociais, quando da escrita do segundo volume do Dicionário de semiótica - em colaboração com diversos pesquisadores da época - percebemos que a cada verbete e, portanto, a cada colaboração, outros direcionamentos eram propostos.

Além daquele grupo que se identificava com a vontade de Greimas de refinar o instrumental teórico a fim de conquistar novos territórios no estudo das ciências humanas e sociais, como nos diz Tatit (1997, p.12), haveria ainda mais duas outras tendências teóricas. Vejamos:

\footnotetext{
${ }^{1}$ Greimas, A. J. e Courtés, J. Sémiotique. Dictionnaire raisonné de la théorie du langage, II.Paris: Hachette, 1986.
} 
As duas outras tendências, talvez mais periféricas mas igualmente sólidas, ressaltavam, no primeiro caso, a necessidade de fortalecimento do instrumental epistemológico da semiótica por meio da formalização matemática dos seus conceitos fundadores e, no segundo, a necessidade de dinamização das estruturas e de concepção de um plano especial para se considerar as oscilações tensivas.

Anos depois da publicação do segundo volume do dicionário, ciente de que a teoria semiótica ainda devia um modelo que desse conta de responder às inquietações quanto aos conteúdos sensíveis do discurso, em 1991, em coautoria com Jacques Fontanille, Greimas publica o livro Sémiotique des passions.Des etats de choses aux etats d'áme. Segundo Tatit (1997, p.13):

Para instituir de vez um modelo que desse conta dos conteúdos passionais, foi necessário repropor o nível epistemológico da teoria com o auxílio de dois simulacros complementares, um tensivo e outro fórico, para configurar as precondições que engendrariam o ser do sentido. Este "ser" não está muito longe, a nosso ver, da construção de um simulacro do sujeito enunciativo, possuidor, como tal, de percepção e sentimento.

Em Sémiotique des passions (1991), temos, portanto, o embrião de um novo direcionamento da semiótica greimasiana. Se antes os elementos inteligíveis regiam os sensíveis, agora, diante de um "corpo que sente", a teoria se vê obrigada a repensar se não seriam os conteúdos sensíveis a reger os inteligíveis. Tal inversão redundaria em uma nova abordagem quanto ao universo do sentido e mostraria um Greimas mais afinado com aquele grupo do Dicionário que buscava maior dinamização do modelo, considerando as oscilações tensivas do discurso. 
Esse grupo preocupado com as oscilações tensivas do discurso, na verdade, é bem reduzido e podemos resumir seus expoentes, hoje, a dois pesquisadores franceses: Claude Zilberberg e Jacques Fontanille. De modo que, no que diz respeito à nossa pesquisa, são as discussões teóricas de Zilberberg que pretendemos convocar.

Embora essa nova abordagem pareça um pouco distante do que a semiótica greimasiana propunha de início, Claude Zilberberg faz questão de frisar ${ }^{2}$ que a semiótica tensiva não se trata de uma nova semiótica, que se opõe à semiótica dita narrativa, mas sim uma nova abordagem que, por se interessar mais pelos fenômenos de caráter gradual, dinâmico e contínuo do discurso, não poderia se utilizar de uma abordagem binária, estática, descontínua e estritamente narrativa como o percurso gerativo do sentido canônico. Assim, a semiótica tensiva trará modelos capazes de estudar o discurso em ato, a "enunciação viva", a presença e as paixões.

Como nos diz Luiz Tatit na orelha da edição brasileira de Razão e Poética do Sentido (ZILBERBERG, 2006a), diferentemente de outros autores que buscaram responder às lacunas do modelo de Greimas por meio do aprimoramento ou de suas

\footnotetext{
2 Conforme nos diz em sua página da Internet pessoal: "Ce qu'on appelle parfois la sémiotique tensive n'est pas une autre sémiotique, qui s'opposerait à la sémiotique dite structurale. Elle s'intéresse, de fait, à un ensemble de phénomènes discursifs que leur caractère graduel, continu, dynamique ou affectif rendait difficilement accessibles à une approche discontinue, binaire, statique et strictement narrative. Ce faisant, elle découvre l'unité d'un autre domaine de recherches: celui du discours en acte, de l'énonciation vivante, celui de la présence sensible à l'autre et au monde, celui des émotions et des passions."

Disponível em: <http://www.claudezilberberg.net/principal/presentationset.htm>. Acesso em 05/10/2009.
} 
bases epistemológicas ou de seus níveis gerativos, Zilberberg pôs em prática o que ele chamou de "progresso às avessas", explica Tatit (ZILBERBERG, 2006a):

(...) uma forma de evolução teórica baseada essencialmente na releitura dos autores que, a seu ver, tiveram peso especial no delineamento do projeto de ciência greimasiano. (...) Deteve-se especialmente em Saussure (silabação e anagramas), Hjelmslev (rede de dependências e princípio de participação), Brøndal (termo complexo) e, evidentemente, Greimas (valor, narratividade e isotopia).

Pensando então nesse "progresso às avessas" empreendido por Zilberberg, poderíamos inclusive classificá-lo como conservador já que, afinal, os desenvolvimentos ou novas posturas quanto ao universo de sentido propostos pelo pesquisador partem não de novas teorias, mas sim das próprias teorias de base utilizadas por Greimas para o desenvolvimento da semiótica narrativa, inclusive dando peso ao fundador da linguística moderna, Ferdinand de Saussure, e a Louis Hjelmslev, linguista dinamarquês talvez dos mais densos e cujos conceitos foram largamente aproveitados por Claude Zilberberg para a formalização de seu modelo.

De início, ainda preocupado em manter a estrutura do percurso gerativo do sentido, Zilberberg propõe novos níveis além dos três já estruturados por Greimas (fundamental, narrativo e discursivo), de modo que as oscilações tensivas seriam responsáveis por reger o discurso desde suas etapas mais profundas.

"Pour introduire le faire missif", de 1986, é um dos textos afinados com essa preocupação do pesquisador em retomar a noção de geratividade, reconfigurando sua estrutura de modo a acomodar os desenvolvimentos da semiótica tensiva. Resumidamente, o texto trata do "fazer missivo", uma espécie de nível regulador das 
continuidades e descontinuidades de base do discurso. Assim, o fazer missivo teria dois funtivos: o fazer remissivo, disseminando limites e paradas, e o fazer emissivo, transgressor de barreiras ao promover a parada da parada.

O conceito de missividade, além de ter seu desenvolvimento exaustivo em "Pour introduire le faire missif", publicado em 1986 na revista canadense RSSI, ganhou outra versão, mais sucinta, no livro Raison et poétique du sens, de 1998. No entanto, já no segundo volume do Dicionário de semiótica, ainda sob a avaliação de Greimas, assinando o verbete "Génératif (parcours)"3, Zilberberg já discute os níveis tensivo e missivo, o que acaba por situar tais conceitos no seio da própria semiótica greimasiana - a geratividade.

É ao encontro do conceito de missividade introduzido por Claude Zilberberg e ao seu posterior caminhar na semiótica tensiva que nossa pesquisa se apresenta. Para isso, buscaremos cotejar os três textos fontes em que o conceito é desenvolvido, ou seja, o artigo "Pour introduire le faire missif" (1986), publicado na revista $R S S$; o capítulo homônimo ao artigo, publicado no livro Raison et poétique dus sens (1988); e o verbete "Génératif (parcours)", contido no segundo volume do Dicionário de semiótica (1986).

A fim de demonstrar não apenas sua efetividade, mas também sua extensão no que diz respeito às possibilidades de aplicação, promoveremos a análise de dois textos literários: o poema "Ciao cadáver", de Delmo Montenegro, publicado em seu livro homônimo, Ciao cadáver, de 2005; e o livro-conto Maciste no inferno (raconto), de Valêncio Xavier, publicado em 1983.

\footnotetext{
${ }^{3}$ Greimas, A. J. e Courtés, J. "Génératif (parcours)". Sémiotique. Dictionnaire raisonné de la théorie du langage, II. Paris: Hachette, 1986, p.97.
} 
Desse modo, no que diz respeito à estruturação de nosso trabalho, além dessa Introdução e da Conclusão, ele é composto de mais cinco capítulos, a saber: "1. Introduzindo o fazer missivo: geratividade e transvalorização", em que discorremos sobre as reflexões de Zilberberg a respeito do processo de transvalorização no percurso gerativo do sentido; "2. O fazer missivo: conceituação", em que procuraremos explanar o conceito de missividade, sempre recorrendo aos três textos em que tal conceito aparece (o verbete "Génératif (parcours)" presente no segundo volume do Dicionário de semiótica e as duas versões de "Pour introduire le faire missif", uma do livro Raison et poétique du sens e outra da revista canadense RSS1); "3. A ressonância da surpresa: acontecimento e missividade", em que empreenderemos uma tentativa de aproximação entre os conceitos de missividade e acontecimento; e, finalmente, "4. Análise de "Ciao cadáver", de Delmo Montenegro" e "5. Análise de Maciste no inferno (raconto), de Valêncio Xavier", dois capítulos de aplicação dos modelos tensivos para a análise de textos literários. 


\section{INTRODUZINDO O FAZER MISSIVO: GERATIVIDADE E TRANSVALORIZAÇÃO}

Rien ne se perd au royaume du signe

(Claude Zilberberg)

O texto "Para introduzir o fazer missivo" (ZILBERBERG, 2006a) se apresenta, logo em sua primeira página, como a segunda parte de uma reflexão sobre o conceito de geratividade na teoria semiótica greimasiana. A ambição de Zilberberg é a de garantir à sintaxe uma atividade própria ${ }^{5}$, desenvolvendo a foria como mobilizadora da semântica fundamental. Assim, interpretar o termo "introdução", no título do texto, como uma "iniciação" ou "apresentação" da missividade parece-nos ingenuidade. A proposta de Zilberberg, já no título, é a de introduzir no sentido de inserir, incluir os níveis tensivo e missivo no próprio percurso gerativo do sentido - o patamar missivo seria o lugar de mediação entre a sintaxe tensiva e a sintaxe narrativa e, mais do que isso, penetraria ou ressoaria em todos os níveis subsequentes do percurso (ZILBERBERG, 2006a, p.129):

\footnotetext{
${ }^{4}$ A versão do texto que estamos considerando é a tradução em português do livro Razão e poética do sentido, de 2006.

${ }^{5}$ Segundo Zilberberg (2006a, p.130): "A sintaxe ainda não recebeu a consideração merecida e, para dizer sem rodeio: mesmo se the fosse atribuído um lugar igual ao da semântica, ela estaria insuficientemente contemplada. Pediu-se, pede-se ainda à sintaxe que 'mobilize' a semântica, do que, aliás, ela se incumbe muito bem... A sintaxe é vista através da semântica e ninguém se preocupa com uma possível sobra, com alguma face ocultada justamente por esse tipo de apreensão. Nem com alguma especificidade, alguma atividade própria da sintaxe, ninguém se preocupa. As linhas escritas adiante se empenham em preencher essa lacuna."
} 
As duas hipóteses diretoras enunciam-se por si: introduzimos como razões primeiras dados tensivos na medida em que são de imediato figuras e valores. Em segundo lugar, a forma do conteúdo torna-se em si uma semiose, ao mesmo tempo determinada e livre, determinada pela ordem das conversões, livre para interromper a cadeia transvalorativa em qualquer do níveis.

Destarte, ao longo de "Para introduzir o fazer missivo", o autor vai nos mostrando como o conceito de missividade altera diversos elementos dos níveis tensivo e narrativo, passando pela foria, modalidades, actantes e ainda discorrendo sobre o efeito do missivo no tempo e espaço figurais.

Corroborando a afirmação de Zilberberg de que a discussão sobre o fazer missivo se inseria como a segunda parte de uma reflexão sobre a geratividade, encontraremos, como já mencionado em nossa "Introdução", parte do desenvolvimento do conceito no verbete "Génératif (parcours)", do segundo volume do Dicionário de semiótica.

Tal verbete se inicia com a revisão de qual seria, até então, a configuração do percurso gerativo do sentido. Assim, seriam três os seus princípios constitutivos:

1. A dualidade dos componentes sintáxicos e semânticos;

2. A estruturação dos níveis como estágios e a conversão que faria possível a passagem de um nível ao outro;

3. A escolha de um nível fundamental que colocaria os outros níveis como pressuponentes. Ou seja, um nível que regeria todos os outros.

Desse modo, o percurso estaria estruturado, semanticamente, pelas relações de contrariedade e contradição (S1, não-S1, S2, não-S2) e, sintaxicamente, pelas 
operações de asserção e negação. Como essas operações redundariam em valor, espaço, tempo e actantes nos níveis subsequentes (narrativo e discursivo) não possuía explicação convincente.

Zilberberg continua então sua reflexão propondo mais três princípios que lançariam luz na reflexão sobre a geratividade: o de desenvolvimento, que afetaria o número de níveis a se reter; o de "descendência", que dividiria todo nível em dois níveis correlatos: um pressuposto (anterior) e um pressuponente (posterior), sendo a expressão operatória do princípio de continuidade que Zilberberg esperava dar ao percurso; e o princípio de alternância, que exigiria que todo dado sintáxico e semântico fosse ao menos uma vez categorizado.

A proposta desses três princípios por Zilberberg é muito interessante. No que diz respeito ao princípio de descendência, o autor exemplifica esses dois níveis correlatos (pressuposto e pressuponente) usando os sufixos franceses -al (como pressuposto) e -if (pressuponente). Para entendermos melhor tal conceito, pensamos na atual diferenciação entre o que o pesquisador chama de "figural" e "figurativo", sendo o primeiro da ordem da imanência e o segundo, da ordem da manifestação. Sem adiantar, vamos ao gráfico que o próprio autor nos dá de como ficaria o percurso gerativo à luz dos três princípios expostos (GREIMAS, A. J. e COURTÉS,J, 1986, p.98) :

\footnotetext{
${ }^{6}$ No original, déhiscence.
} 


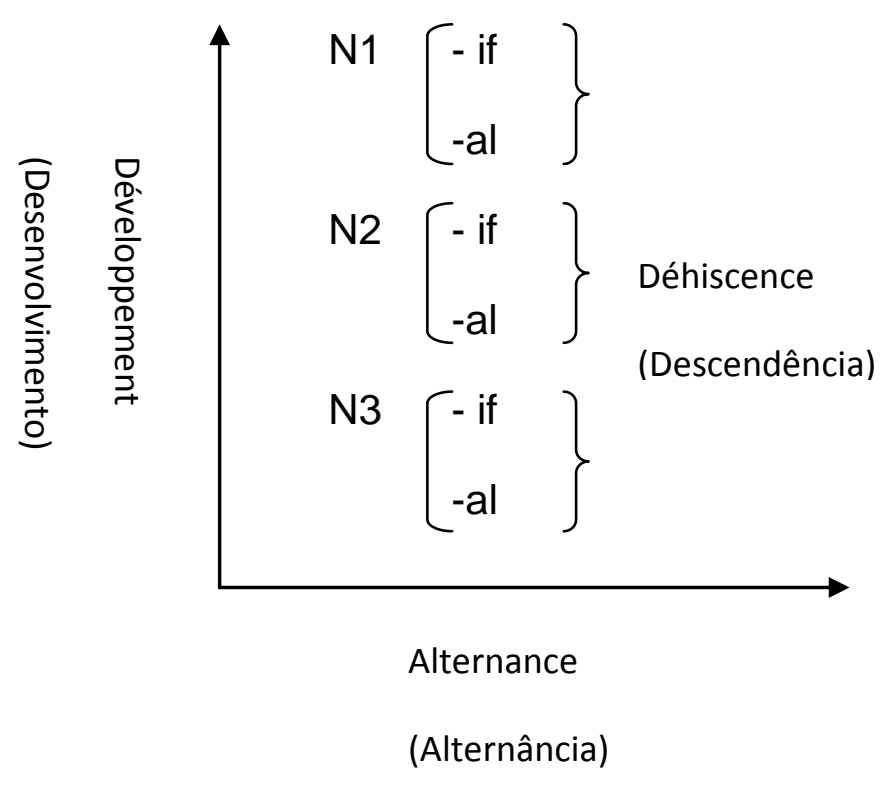

Figura 1 - Gráfico do "desenvolvimento, descendência e alternância"

Assim, todo nível convocaria tanto o seu nível anterior como o seu nível subsequente, como se ressoassem um no outro, fazendo do percurso gerativo menos uma hierarquia e mais uma rede. Como nos diz Zilberberg (GREIMAS, A. J. e COURTÉS,J, 1986, p.98), "le valeurs, le temps, l'espace, l'actantialité sont toujours là, toujours déjà là."

A esse ponto, o autor se propõe a articular o nível tensivo-fórico segundo o princípio da descendência. Ou seja, dividir a tensividade em "tensif" ${ }^{7}$ e "tensal". Desse modo, no nível "tensal", a tensividade estaria dividida em dois regimes: o remissivo e o emissivo; tais regimes encontrariam, no nível "tensif" (tensivo), seus funtivos universais do fazer, ou seja, a parada (remissivo) e a continuação (emissivo). Vejamos o quadro (GREIMAS, A. J. e COURTÉS,J., 1986, p.99):

\footnotetext{
${ }^{7}$ Optamos por não traduzir os termos propostos por Zilberberg de modo a manter a coerência sufixal criada pelo autor.
} 


\begin{tabular}{|l|l|l|l|}
\hline \multirow{2}{*}{ Tensividade } & "Tensif" & $\begin{array}{l}\text { Parada } \\
\text { (espera) }\end{array}$ & $\begin{array}{l}\text { Continuação } \\
\text { (relaxamento) }\end{array}$ \\
\cline { 2 - 4 } & "Tensal" & $\begin{array}{l}\text { Remissão } \\
\text { (retenção) }\end{array}$ & $\begin{array}{l}\text { Emissão } \\
\text { (distensão) }\end{array}$ \\
\hline
\end{tabular}

Figura 2 - Quadro "Tensif/Tensal"

Tal nível tensivo será seguido do nível da modalização, o qual também será dividido em dois, porém, pelo caráter extenso da modalidade, que acaba por dirigir a cadeia discursiva, o nível da modalização será articulado pelo par "directal"/ "directif". Vejamos o quadro resumo (GREIMAS, A. J. e COURTÉS,J., 1986, p.99):

\begin{tabular}{|l|l|l|l|}
\hline \multirow{2}{*}{ Modalidade } & "Directif" & Obrigação & Volição \\
\cline { 2 - 4 } & "Directal" & Excesso & Falta \\
\hline
\end{tabular}

Figura 3 - Quadro "Directif/Directal"

O próximo nível, o da narratividade, segundo o princípio da descendência proposto por Zilberberg, carrega suas configurações próprias, no entanto, como pressuponente, ele recebe ou se rende às configurações dos níveis anteriores. Assim, o que se manifesta no nível narrativo já vem da configuração tensiva e aspectual dos valores de remissividade e emissividade, do excesso e da falta. Ou seja, embora no nível narrativo o sujeito esteja em busca de estar conjunto ou disjunto a um objeto, antes de tudo, esse sujeito está entrando em conjunção ou em disjunção com um valor. Recorrendo à oposição saussuriana, o valor estaria para o objeto como o significado estaria para o significante.

Zilberberg propõe mais dois quadros para categorizar o nível narrativo. Um quadro articulado pela distinção "jonctal" / "jonctif" e outro quadro articulado pela distinção "disjonctal" / "disjonctif". Vejamos (GREIMAS, A. J. e COURTÉS,J, 1986, p.100): 


\begin{tabular}{|l|l|l|l|}
\hline $\begin{array}{l}\text { Narratividade } \\
\text { (atualização) }\end{array}$ & "Disjonctif" & Falta & Frustração \\
\cline { 2 - 4 } & "Disjonctal" & Disjunção & Não-conjunção \\
\hline
\end{tabular}

Figura 4 - Quadro "Disjonctif/Disjonctal”

\begin{tabular}{|l|l|l|l|}
\hline $\begin{array}{l}\text { Narratividade } \\
\text { (realização) }\end{array}$ & "Jonctif" & Prazer & Satisfação \\
\cline { 2 - 4 } & "Jonctal" & Não-disjunção & Conjunção \\
\hline
\end{tabular}

Figura 5 - Quadro "Jonctif/Jonctal”

Já o nível discursivo, pelo princípio do desenvolvimento, conjugaria os níveis em -if, ou seja, o nível "tensif", segundo a articulação parada/continuação; o nível "aspectif", segundo a saliência e a passância; o nível modal (-if porque considerada a articulação gerada pelo "directif"), categorizado segundo obrigação/volição e o "narratif", segundo o par prazer/satisfação ou falta/frustração.

Não entraremos em grandes detalhes acerca dessas divisões propostas por Zilberberg por acreditarmos que esse foi apenas o embrião das mudanças propostas pelo autor. Desse modo, a oposição usando os sufixos -al e -if só se mantém, hoje em dia, no par figural/figurativo.

O que acreditamos importante reter do verbete é a noção de geratividade e de transvaloração que o autor discute. Como Zilberberg mesmo conclui em seu texto, as grandes categorizações semióticas não devem funcionar mais segundo o par presença/ ausência, e sim por um princípio de "deformação", ou seja, espaço, tempo, valor, actantes...etc não estão ausentes num nível e presente no outro, mas sim variando sua forma de nível a nível, segundo os regimes impostos por cada patamar. Assim, de um nível a outro, o que há é o enriquecimento, muito em razão 
do princípio de conservação que torna implícito o nível pressuposto no nível pressuponente, mas também pelo fato do nível subsequente adicionar algo original às articulações recebidas do nível anterior.

Passando para o texto "Para introduzir o fazer missivo", tanto em sua versão do livro Razão e poética do sentido como da revista canadense RSSI, a discussão sobre a geratividade e o lugar do nível missivo no percurso gerativo do sentido permanece. Porém, diferentemente do que ocorre no verbete sobre geratividade do segundo volume do Dicionário de semiótica, Zilberberg não se preocupa tanto com grandes esquematizações, como, por exemplo, os quadros em que dividia os níveis segundo os sufixos franceses -if e -al. No entanto, o pesquisador mantém sua posição no que diz respeito a um nível "reger" seu subsequente, explicando tal movimento se dar em razão do princípio de "reversão". O princípio de reversão seria responsável por regular,pois, a passagem da imanência à manifestação. Segundo o autor ( ZILBERBERG, 2006a, p.131):

Para a imanência, que todo nível pressuponente converte, mediante dados funcionais, o nível pressuposto.

Para a manifestação, que o nível pressuposto predica o nível pressuponente; ou ainda: o pressuponente tem estatuto de "constituinte" e o pressuposto, de "caracterizante ${ }^{8 "}$.

A insistência do autor nesse "ressoar" de valores e articulações de um nível ao outro se dá pela tentativa de se manter a noção de continuidade no percurso gerativo e de marcar a posição de que o nível missivo ou, anteriormente, o nível tensivo, está, antes de qualquer categorização mais superficial, regendo e ${ }^{8}$ Cf. HJELMSLEV, L. Le langage. Paris: Minuit, 1966. 
selecionando valores os quais ganharão "concretude" no nível discursivo. Pensando no percurso como uma estratificação vertical, em que os níveis pressupostos estariam em sua base e os níveis pressuponentes em seu topo, realizando um percurso ascendente nesse percurso, o que teríamos seria o processo de conversão de valores; em sentido oposto, ou seja, descendente, haveria o processo de predicação.

Sendo o percurso gerativo um simulacro disposto a esquematizar o processo de transvalorização, seus níveis não seriam nada mais do que "recortes" desse processo, ou melhor, como se a teoria tivesse tirado "fotos" de diferentes momentos do movimento de transvalorização e assim estabelecido seus níveis. De início, na concepção de Greimas, três seriam os "recortes" essenciais no processo de transvalorização - os níveis fundamental, narrativo e discursivo; já na concepção de Zilberberg, ao menos no que diz respeito às suas reflexões de 1986, haveria ao menos quatro "recortes" a serem considerados - os níveis tensivo, missivo, narrativo e discursivo. Cada um desses níveis, por sua vez, como nível pressuposto, promove, instiga, certo tipo de valores; como nível pressuponente, acolhe e converte os valores recebidos do nível que pressupõe, conformando-os, ou, como Zilberberg mesmo sugeriu no verbete sobre geratividade, "deformando-os" de acordo com suas próprias imposições formais. Segundo Zilberberg (2006a, p.138):

O fazer missivo recebe os valores tensivos e proporciona ao nível narrativo, de acordo com o dispositivo que lhe é próprio, dois tipos de valores missivos: os valores emissivos e os remissivos. 
Ou ainda, reforçando o mesmo pensamento em trecho publicado apenas na versão de "Para introduzir o fazer missivo" para a revista RSSI (ZILBERBERG, 1986, p.239):

Ainsi, les données tensives - mais le données sont des contraintes donnent leur sens aux données missives, lesquelles, à leur tour, informent, selon la double acception de ce vocable, les données aspectuelles, lesquelles vont diriger les données modales et narratives.

Zilberberg prosseguirá o desenvolvimento de seu texto empreendendo,pois, a discussão acerca de como o fazer missivo ressoaria em seus níveis subsequentes. Para isso, passemos ao próximo capítulo, em que discussão mais detalhada acerca das implicações do fazer missivo no percurso gerativo do sentido será feita. 


\section{O FAZER MISSIVO: CONCEITUAÇÃO}

Tout commence par une interruption

(Paul Valéry)

Tendo discutido a ideia de Claude Zilberberg de situar a missividade no seio da discussão sobre geratividade e transvaloração e de introduzir o nível missivo como mediador dos níveis tensivo e narrativo, cabe-nos agora discutir, afinal, a constituição do próprio fazer missivo.

Como o nível anterior ao missivo seria o tensivo, Zilberberg introduz um tópico em "Para introduzir o fazer missivo" intitulado "Desenvolvimento da foria" em que articula a diretividade da foria (tensão/relaxamento) com a distinção operatória extenso/intenso. A partir daí, os elementos intensos estariam ligados ao estado de tensão, correspondendo à saliência, ao excesso, ao compacto; já os elementos extensos estariam ligados ao relaxamento, correspondendo à passância, àquilo que permeia a cadeia, tecendo-a. A intenção de Zilberberg em fazer tal articulação é a de, de alguma maneira, explicar como a foria produz o tempo e espaço figurais.

Assim, uma temporalidade figural teria como seus funtivos, "na perspectiva do intenso, uma temporalidade expectante que espera a processualização que deverá extenuá-la. Na perspectiva do extenso, uma temporalidade originante que repara talvez em nome de algum princípio de constância diante da qual o eu é tanto o instigador como o beneficiário - essa perda." (ZILBERBERG, 2006a, p. 132) 
É interessante observar que o autor, nesse momento, conceitua a espera como a memória do porvir e lembrança como a espera do passado, as quais espera e lembrança - fazem do eu um espaço mnésico.

Do mesmo modo, a espacialidade figural teria como funtivos (ZILBERBERG, 2006a: 133):

$\mathrm{Na}$ perspectiva do intenso: uma espacialidade concentradora, circunscritiva, interpretável sintaxicamente como expansão da pequenez e que consumiria o espaço ao redor. Na perspectiva do extenso: uma espacialidade difusora, ocupante, que consumiria, autotrófica!, o seu centro.

Nesse momento do desenvolvimento do texto, Zilberberg já está próximo do que chamará de fazer missivo. A partir de uma observação oral de L. Panier sobre a noção de "antiprograma", Zilberberg levanta a suposição de que todo momento da cadeia é um lugar de mobilização emocional e, eventualmente, de resolução de um contraste entre um programa e um antiprograma.

Ao antiprograma, (parada), Zilberberg corresponde o fazer remissivo e ao programa (parada da parada), o fazer emissivo, ou continuativo. Ou seja, o fazer missivo seria uma função dotada dos funtivos remissivos e emissivos, aos quais estariam agregados, respectivamente, subvalores de inibição, parada e "stase"; e de ardor e arroubo, "ek-stase". Graficamente: 
FUNTIVOS

SUBVALORES

MISSIVO (função)

REMISSIVO

programa

parada

inibição,

parada,

"stase"

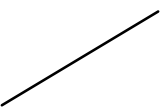

ardor,

arroubo,

"ek-stase"

Figura 6 - Estrutura do fazer missivo

É interessante observar que Zilberberg comenta a qualificação do texto como uma progressão por Louis Hjelmslev. Assim entendido o texto, o autor vai conceituar que só a partir da prova do fazer remissivo (parada) é que o fazer emissivo (parada da parada) poderá ascender e dominar.

O fazer missivo subjuga tempo e espaço proporcionando, nos dois regimes figurais, uma emissividade e uma remissividade. Espaço e tempo estariam, ainda, diretamente relacionados, porém, em razão inversa um do outro. Desse modo, toda 
remissão se configuraria como uma cronopoiese $^{9}$ em relação ao tempo e como fechamento quanto ao espaço; e toda emissão se configuraria como uma cronotrofia em relação ao tempo e como abertura em relação ao espaço (ZILBERBERG, 2006a: 137). Em síntese:

\begin{tabular}{|c|c|c|c|}
\hline FUNÇõES & EU & AGORA & AQUI \\
\hline & $\begin{array}{c}\text { Fazer remissivo } \\
\text { (intenso) }\end{array}$ & Cronopoiese & Fechamento \\
Funtıvos & $\begin{array}{c}\text { Cronotrofia } \\
\text { (extenso) }\end{array}$ & Abertura \\
& & & \\
\hline
\end{tabular}

Figura 7 - Fazer remissivo e fazer emissivo

Ainda sobre o tempo, uma temporalidade remissiva é configurada pelo atraso e pela espera. Ou seja, enquanto o fazer remissivo for dominante, tratando-se a remissão de uma parada, o tempo emissivo será suspenso e inibido. Como nos diz Zilberberg (2006a: 135), "o tempo emissivo se move, oscila... começa quando o tempo remissivo se extenua e se acaba."

\footnotetext{
${ }^{9}$ Diz-se que o fazer remissivo gera cronopoiese (criação de tempo) porque o sujeito, estando em remissão, ou seja, parado, está em estado de espera. Já a cronotrofia (alimentação do tempo), fruto de um fazer emissivo, tem sua justificativa pelo fato do sujeito estar em ação, alimentando o tempo com seu percurso de busca.
} 
Desse modo, antes do emissivo surgir, é necessário que um tempo remissivo esteja em operação, garantindo, assim, a progressão do texto por meio de paradas e continuações. Segundo Tatit (1998: 17):

(...) o nível tensivo-fórico permanece como horizonte ontológico, sustentando a crença de que o homem visa preservar sua integridade interior: tudo que provém da primeira parada, da primeira tomada de posição remissiva, é um esforço no sentido de restabelecer o contínuo, esse elo profundo que neutraliza as funções actanciais em virtude da junção plena.

É natural que o tempo emissivo cesse uma remissividade, porém, a remissividade interrompendo um percurso emissivo é sentido como surpresa, desordem e interrupção - interrupção essa que acaba por romper o próprio sujeito. Assim, a oscilação tensiva tensão/distensão ressoará no nível missivo como parada (remissão) e parada da parada (emissão).

O nível missivo, num movimento ascendente no percurso gerativo do sentido, será espaço de mediação entre a sintaxe tensiva e a sintaxe narrativa. Ou seja, o fazer missivo, na medida em que é nível pressuposto do fazer modal, controlará e categorizará as modalidades. Distinguindo as modalidades do fazer (factivas) das modalidades de estado (páticas) e as articulando com os valores remissivos e emissivos, Zilberberg propõe o seguinte cadastro modal (ZILBERBERG, 2006a, p. 139): 


\begin{tabular}{|c|c|c|}
\cline { 2 - 3 } \multicolumn{1}{c|}{} & FAZER REMISSIVO & FAZER EMISIVO \\
\hline \multirow{2}{*}{ MODALIDADES FACTIVAS } & $\begin{array}{c}\text { Cognitiva: ignorar } \\
\text { Pragmática: dever }\end{array}$ & $\begin{array}{c}\text { Cognitiva: prever } \\
\text { Pragmática: querer }\end{array}$ \\
\hline MODALIDADES PÁTICAS & $\begin{array}{c}\text { Cognitiva: espantar-se } \\
\text { Pragmática: interromper-se }\end{array}$ & $\begin{array}{c}\text { Cognitiva: crer } \\
\text { Pragmática: esperar }\end{array}$ \\
\hline
\end{tabular}

Figura 8 - Quadro de cadastro modal segundo os fazeres emissivo e remissivo

$\mathrm{Na}$ versão de "Pour introduire le faire missif" do livro Raison et poétique du sens, o autor não explica como tal cadastro modal se desenvolveria. $O$ que se poderia especular é que, em determinado discurso, por trás de uma manifestação pática de espanto e interrupção e de uma manifestação de ação por dever, haveria, imanentemente, a ativação dos valores remissivos. Por sua vez, diante de uma manifestação de previsibilidade ou espera (não no sentido de esperar, mas no sentido mesmo de "já se esperar"), de crença e de volição, haveria em imanência os valores de emissividade ${ }^{10}$.

No entanto, na versão escrita para a revista canadense RSSI, há um subtópico subsequente ao quadro das modalidades entitulado "Freud et le contrat répressif" (ZILBERBERG, 1986, p. 241). Acreditando não ser necessário entrar em detalhes acerca de todas as modalidades expostas com exceção de a do dever, Zilberberg convocará Freud para discutir acerca dos discursos da "interdição", da "repressão". Comenta o pesquisador que os discursos repressivos podem neutralizar

\footnotetext{
${ }^{10}$ Mais adiante, no próximo capítulo, retomaremos esse quadro para compará-lo com as noções de pervir e sobrevir.
} 
a oposição "prazer - desprazer". Desse modo, haveria o prazer do gozo (plaisir de jouissance) e o prazer da renúncia (plaisir de renoncement). Diz Zilberberg (1986, p. 242):

Cette catastrophe est très probablement au coeur de l'éthique: le plaisir de renoncement est modalisé comme "supérieur", "élevé", "sublime" en raison du gain que constitue l'appropriation (ou l'initiation) des figures intenses que le faire rémissif emporte avec lui. Comme si le renoncement était une jouissance supérieure.

No discurso religioso, principalmente católico, a valorização da renúncia dos prazeres, por exemplo, seria um exemplo de um percurso remissivo que não seria, necessariamente, sentido como disfórico pelo sujeito. A renúncia seria, e de fato parece ser, valorizada como superior.

Os valores missivos também ressoariam nas articulações actanciais. Sendo as oscilações tensivas nada mais do que a tentativa do sujeito de equilibrar ora o excesso, ora a falta, sempre em busca daquela junção plena anterior a qualquer parada ou descontinuidade, Zilberberg reformulará as relações entre sujeito e objeto e entre sujeito e sujeito de acordo com os valores emissivos. Assim, a emissividade constituiria um elo de identidade do ponto de vista objetal e subjetal, criando relações do tipo sujeito/subobjeto (demonstrando a atratividade do sujeito por seu objeto) e sujeito/transujeito (ratificando a fidúcia entre destinador e destinatário); enquanto a remissividade imporia a descontinuidade do ponto de vista objetal e subjetal, criando, por sua vez, relações do tipo sujeito/abjeto (sentimento de aversão do sujeito em relação ao seu objeto) e sujeito/anti-sujeito (marcando a descontinuidade e oposição entre o percurso dos dois sujeitos). 
Além do movimento de transvaloração de um nível a outro, encontraremos no texto "Para introduzir o fazer missivo" uma divagação a respeito de como os valores remissivos e emissivos instruiriam inclusive as interações éticas (entre sujeitos) e a forma de atração estética (entre sujeito e objeto). Tal divagação é derivada das próprias articulações actanciais. Dessarte, numa dimensão estética, sujeito e objeto sofreriam uma inversão no que diz respeito à articulação "ativação vs. passivação" de modo que o sujeito, arrebatado pelo objeto, se apassivaria em relação a ele; já as interações éticas exigiriam, devido à moralização, concomitantemente a um sujeito ativo, um sujeito passivo, disposto a obedecer às ordens morais e éticas.

Podemos concluir, assim, que o fazer missivo parece ser um conceito profícuo aos mais diversos tipos de análise, ressoando suas oscilações e valores por todos os níveis do percurso gerativo do sentido. A seguir, trataremos do "ressoar" da missividade no conceito tensivo de acontecimento. 


\section{A RESSONÂNCIA DA SURPRESA: O ACONTECIMENTO E A MISSIVIDADE}

-How did you go bankrupt?

Two ways, gradually and then suddenly.

(Ernest Hemingway, em The sun also rises)

O diálogo acima, retirado do livro The sun also rises (2006), de Ernest Hemingway, é capaz de exemplificar, com duas palavras, como um evento, ou objeto, pode entrar no campo de presença de um sujeito. Ao ser questionado a respeito de como entrou em falência, a personagem do livro responde: "De duas maneiras, gradualmente e, então, de repente." A princípio, poderíamos tomar tal resposta como um paradoxo. Como algo aconteceria gradualmente e de repente ao mesmo tempo?

Para responder tal pergunta, outro comentário literário, desta vez, de Paul Valéry ${ }^{11}$ :

Notion des retards.

Ce qui est (déjà) n'est pas (encore) - voici la surprise.

Ce qui n'est pas (encore) est (déjà) - voilà l' attente.

E a tradução sugerida por Tatit (1997):

Noção dos atrasos.

O que (já) é não é (ainda) - eis a surpresa.

O que não é (ainda) (já) é - eis a espera.

${ }^{11}$ VALÉRY, P. Cahiers, Tome 1. Paris: Gallimard/La Pléiade, 1973, p. 1290. 
A nosso ver, tanto a divagação de Valéry, quanto o diálogo de Hemingway tratam da velocidade de apreensão do sujeito em relação ao seu objeto. Ou seja, o que "já é", um "fato", algo novo a penetrar o campo de presença, dependendo de sua velocidade e da velocidade esperada pelo sujeito que o percebe, pode ser vivenciado como surpresa, se rápido demais; enquanto "o que não é ainda", aquilo que o sujeito espera que penetre seu campo de presença, se devagar demais, é sentido como atraso, prolongando a espera do sujeito.

Assim, no caso do diálogo de Hemingway, o sujeito estava percebendo o fato de sua falência em um tempo mais lento, gradual. No entanto, a nosso ver, talvez por uma lentidão demasiada, o objeto (a falência) "escapou" da percepção do sujeito, dispersando sua atenção. No entanto, calculando a velocidade da falência como lenta, quando ela de fato se faz notar pelo sujeito, "já foi", ou seja, acelerou, confundindo seus limites de identificação pelo excesso de instantaneidade, arrebatando o sujeito. Eis o acontecimento.

Ao longo do desenvolvimento do modelo tensivo, o conceito de missividade, ao menos sob tal título, foi aos poucos se esvaecendo. No atual estado da semiótica tensiva, surge outra conceituação-chave: o acontecimento. Marcando presença como subtópico no texto "Síntese da gramática tensiva" (Zilberberg, 2006b), o acontecimento, um ano mais tarde, ganhou o espaço de um artigo em "Louvando o acontecimento" (Zilberberg, 2007), além de um capítulo inteiro - intitulado "Centralidade do acontecimento" - no livro Eléments de grammaire tensive (Zilberberg, s/d), ainda a ser publicado no Brasil. A crescente importância da ideia de acontecimento para a semiótica tensiva é, pois, notável. 
O objetivo de nosso capítulo é o de discutir as similaridades e diferenças entre esses dois conceitos-chave da semiótica tensiva - a missividade e o acontecimento - a fim de demonstrar como os movimentos de remissão e emissão continuam a ressoar no modelo tensivo.

O artigo "Louvando o acontecimento" (ZILBERBERG, 2007) se inicia propondo uma questão: de que um fato é feito? Respondendo a esse questionamento, o autor prefere definir o fato por meio de seu correlato: o acontecimento. Diz Zilberberg (2007: 16):

"(...) o acontecimento é o correlato hiperbólico do fato, do mesmo modo que o fato se inscreve como diminutivo do acontecimento."

Segundo o autor, o fato seria definido por valências fracas de andamento e tonicidade, sendo um elemento extenso ao longo do discurso. Já o acontecimento teria valências de andamento e tonicidade fortes, caracterizando-se como um elemento intenso (pontual). Dessa forma, os fatos seriam numerosos e acontecimentos, raros.

O acontecimento seria definido como a sincretização de três modos semióticos: o de eficiência, articulando o pervir e o sobrevir, o de existência, composto pelo foco e apreensão; e o de junção, que articula a implicação e a concessão.

O modo de eficiência corresponderia a como uma grandeza se instala no campo de presença de um sujeito. Dessa forma, haveria duas maneiras desse processo se efetuar: a pedido ou inesperadamente. Se uma grandeza aparecer no campo de presença segundo os cálculos e previsões do sujeito, estaremos diante da 
modalidade do pervir. Do contrário, se a grandeza aparecer sem que o sujeito estivesse a sua espera, teremos a modalidade do sobrevir. O pervir é formado pelas valências da longevidade e da progressividade; enquanto o sobrevir se caracteriza pelas valências da brevidade e da subtaneidade:

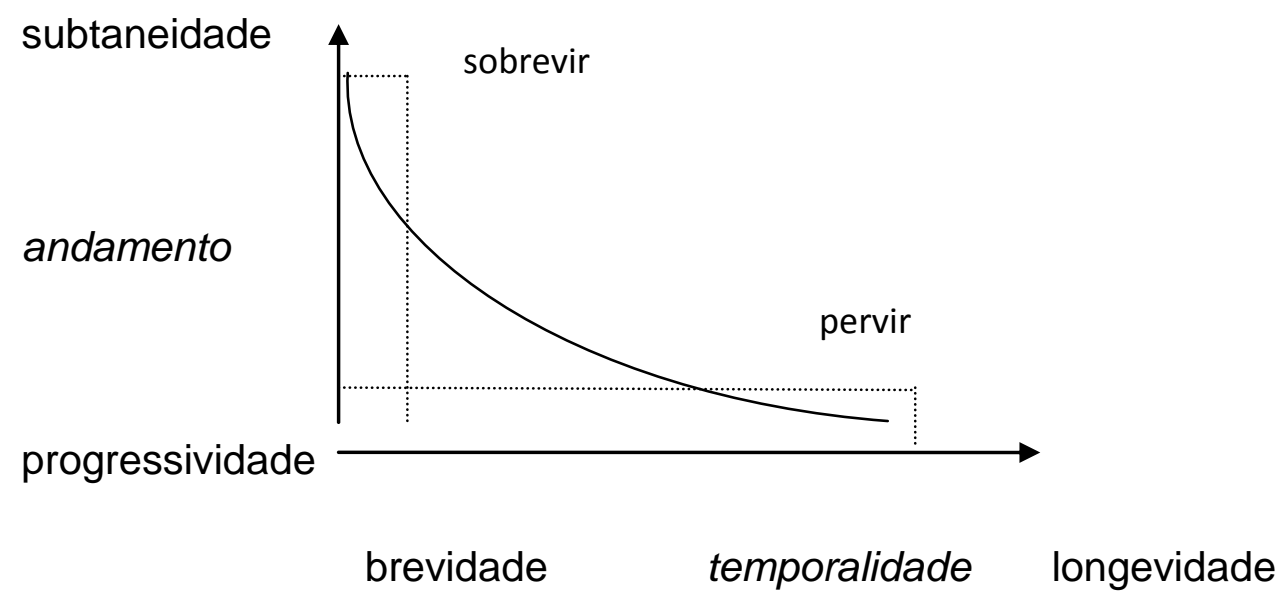

Figura 9 - Gráfico do pervir e sobrevir

Segundo o modo de existência, fato e acontecimento seriam articulados por meio dos processos de foco e apreensão. À focalização, corresponderia o modo de eficiência do pervir. Vindo do francês visée, focalizar seria visar a alguma coisa, planejar, se esforçar no sentido de atingir algum objetivo. Ou seja, a focalização requer um sujeito operador, que age em direção ao seu alvo. Já à apreensão, corresponderia o modo de eficiência do sobrevir. A apreensão define um sujeito arrebatado, admirado, passivo. Segundo Zilberberg (2007:22):

(...) sendo os modos de existência solidários do estado de surpresa do sujeito, devemos dizer, do sujeito espantado, que satura de alguma forma o processo, o sujeito apreende e é ele mesmo apreendido por aquilo que o apreende, pois apreender um 
acontecimento, um sobrevir, é, antes de tudo, e talvez principalmente, ser apreendido pelo sobrevir (...)

O terceiro e último modo semiótico seriam os modos de junção, quais sejam: junção por implicação - "se a, então b" - e junção por concessão - "embora a, entretanto não b". O pervir é um fenômeno regido pela implicação; o sobrevir, pela concessão.

Dessa forma, o acontecimento seria definido pelo sobrevir no modo de eficiência, pela apreensão no modo de existência e pela concessão no modo de junção. $\mathrm{O}$ correlato do acontecimento seria, então, aquele que se caractezaria pelo pervir no modo de eficiência, pela focalização no modo de existência e pela implicação no modo de junção - o exercício.

\begin{tabular}{|c|c|c|}
\cline { 2 - 3 } \multicolumn{1}{c|}{} & \multicolumn{2}{c|}{ DETERMINADOS } \\
\hline DETERMINANTES & \multicolumn{1}{c|}{ O EXERCíCIO } & O ACONTECIMENTO \\
\hline MODO DE EFICIÊNCIA & Pervir & Sobrevir \\
\hline MODO DE EXISTÊNCIA & Focalização & Apreensão \\
\hline MODO DE JUNÇÃO & Implicação & Concessão \\
\hline
\end{tabular}

Figura 10 - Quadro do exercício e do acontecimento

No acontecimento, pois, do ponto de vista da intensidade, o andamento e a tonicidade agem conjuntamente sobre o sujeito, sobrecarregando-o. Assim, a carga excessiva de andamento e tonicidade produz no sujeito, pela falta de comedimento e 
pelo improviso, um desmantelamento modal instantâneo. Diz Zilberberg (2006b: 198-199):

(...) a tonicidade não vem devastar uma parte do sujeito, e sim ele todo. Para essa semiose fulgurante, o acontecimento, quando merece tal denominação, arrebata para si todo o agir, não deixando ao sujeito nada além de suportar. (...) o sujeito se sente arrebatado pelo inesperado.

Já do ponto de vista da extensidade, a temporalidade é "aniquilada". Sendo o acontecimento como um "relâmpago" no campo de presença, o sujeito precisa recompor a temporalidade desacelerando-a e atonizando-a, numa tentativa de restabelecer o comedimento suspenso pelo acontecimento; a espacialidade também sofre pelo acontecimento, o qual virtualiza a escansão do aberto e do fechado, mantendo apenas o fechado no campo de presença do sujeito.

Em síntese, fruto do inesperado, o acontecimento não pode ser antecipado, provocando desconforto e perturbação no sujeito. A esse ponto, já podemos perceber bastante semelhança entre as definições dos funtivos da missividade (o remissivo e o emissivo) e o acontecimento. Enquanto o emissivo é da ordem da continuação, parece muito próximo ao pervir (ou do exercício), àquilo que dura e progride. Já o remissivo, definido como parada e sentido como surpresa pelo sujeito em atividade emissiva, é muito próximo ao sobrevir (ou ao acontecimento) - fruto da concessão, do inesperado, do imprevisível.

Voltando ao texto "Para introduzir o fazer missivo" (ZILBERBERG, 2006a), o autor explana que o retorno do tempo remissivo, quando a emissividade encontra-se em ação, é vivido como uma surpresa, desordem, uma interrupção. Após tal comentário, a noção de "surpresa" ganha um tópico inteiro no texto. Embora ainda 
não chame a surpresa de acontecimento, nos parece bem clara a similaridade entre os dois conceitos. Eis a descrição de surpresa para Zilberberg quando do texto "Para introduzir o fazer missivo" (2006a: 126):

1. A surpresa rompe o(s) percurso(s) (...), mas romper, interromper os percursos, é romper o próprio sujeito(...)

2. A surpresa é uma bifurcação - no sentido catastrofista? - de maneira que o ser atormentado pela dualidade do emissivo e do remissivo se dá conta da dissensão que o aflige. (...)

3. Enfim, esta interrupção do tempo emissivo é um 'retorno ao ponto de partida'; o percurso se transforma em sentido inverso, o que quer dizer que a inversão figural se exibe em retrocesso figurativo (...)

Assim, do mesmo modo em que encontramos, em $1986^{12}$, a conclusão de que o retorno à remissividade quando de uma emissividade em curso, é sentido como surpresa e, a partir daí, a definição desta como um rompimento, uma interrupção, algo inesperado e vivenciado de forma intensa pelo sujeito; anos mais tarde, Zilberberg começa a tratar do acontecimento, conceito que também traz a surpresa e imprevisibilidade em sua definição, algo também com o poder de "arrebatar" o sujeito. Seria, então, a partir dessa comparação, o acontecimento fruto manifestado de uma remissividade imanente que surpreende o sujeito em emissividade?

Em "Para introduzir o fazer missivo" (2006:139) já é possível encontrar um quadro-resumo modal da missividade que parece servir também para a definição modal do exercício e do acontecimento:

\footnotetext{
${ }^{12}$ Considerando a versão francesa de "Pour introduire le faire missif" publicada na revista canadense RSSI.
} 


\begin{tabular}{|c|c|c|}
\cline { 2 - 3 } \multicolumn{1}{c|}{} & $\begin{array}{c}\text { FAZER REMISSIVO } \\
\text { (OU ACONTECIMENTO) }\end{array}$ & $\begin{array}{c}\text { FAZER EMISIVO } \\
\text { (OU EXERCÍCIO) }\end{array}$ \\
\hline MODALIDADES FACTIVAS & $\begin{array}{c}\text { Cognitiva: ignorar } \\
\text { Pragmática: dever }\end{array}$ & $\begin{array}{c}\text { Cognitiva: prever } \\
\text { Pragmática: querer }\end{array}$ \\
\hline MODALIDADES PÁTICAS & $\begin{array}{c}\text { Cognitiva: espantar-se } \\
\text { Pragmática: interromper-se }\end{array}$ & $\begin{array}{c}\text { Cognitiva: crer } \\
\text { Pragmática: esperar }\end{array}$ \\
\hline
\end{tabular}

Figura 11 - Quadro das modalidades segundo a missividade conjugado ao acontecimento e exercício

Observando o quadro poderíamos usar, ao lado do fazer remissivo, o acontecimento. Assim, tanto o acontecimento como o fazer remissivo seriam da ordem do ignorado, do dever, do espanto e da interrupção. Já o fazer emissivo, podendo se aproximar ao exercício, seria da ordem do previsível, do querer, do crer e da espera.

Sendo o acontecimento definido como um sobrevir, um sujeito que apreende e é apreendido, e uma concessão, e a remissividade definida como algo que interrompe, espanta e é ignorada pelo sujeito, não nos parece absurdo que se aproximem os dois conceitos; do mesmo modo, o exercício, se definindo como um pervir, focalização e por uma implicação, não nos parece distante da definição da emissividade, a qual corresponderia ao programa, no sentido semiótico, e promoveria a continuação, sendo esperado e previsto pelo sujeito.

Voltando às reflexões de Zilberberg acerca da geratividade, poderíamos concluir que o conceito de acontecimento faz parte de um nível mais superficial e concreto do percurso, ou seja, o discursivo. É ali, no reino dos atores, figuras, tempo 
e espaço que identificaremos o sujeito atordoado pelo acontecimento, ou satisfeito pelo pervir. No entanto, pervir e acontecimento, gerativamente, seriam manifestações de oscilações tensivas de um nível pressuponente, e, por que não, o missivo.

Acreditamos que assimilar um conceito novo é, antes de tudo, entender sua origem. Assim, embora o conceito de missividade tenha sido, de certa forma, abandonado por Claude Zilberberg, ainda é possível encontrar sua ressonância diluída em postulados mais recentes. Portanto, no que diz respeito ao acontecimento, muito do que se conclui e se diz parece ter tido seu nascimento e até mesmo parte de seu desenvolvimento no texto de 1986, em que Zilberberg propunha "introduzir o fazer missivo" no percurso gerativo do sentido e em que discutia a ressonância da surpresa quando do advento da remissividade, tornando tal texto bastante profícuo no que diz respeito ao entendimento do atual conceito de acontecimento.

Obviamente, as similaridades são superficiais. Não se pode querer transitar pelos dois conceitos como sinônimos: o acontecimento não é sinônimo de remissividade e o exercício não se iguala à emissividade. No entanto, é possível notar muitos pontos de contato, pontos esses que tentamos demonstrar ao longo de nosso texto.

Finalizamos, assim, o que poderíamos chamar de parte de discussão teórica de nossa dissertação. A seguir, buscaremos empreender análises práticas, ou seja, aplicar o modelo tensivo no estudo de textos literários. 


\section{ANÁLISE DE “CIAO CADÁVER”, DE DELMO MONTENEGRO}

"Ciao Cadáver" é o primeiro poema e também a primeira parte do livro homônimo do poeta pernambucano Delmo Montenegro. Claramente mais próximas ao fazer poético dos concretistas paulistanos, as poesias de Ciao Cadáver - o livro, possuem algumas experimentações gráficas, utilização de imagens em sua composição, aproveitamento da mancha da página etc.

"Ciao Cadáver" - o poema -, no entanto, utiliza-se de pouquíssimos recursos gráficos, e aproxima-se mais da poética fundadora de Mallarmé do que de seu desenvolvimento concreto-paulistano. Mesmo assim, o "espalhar de palavras" mallarmeniano aparece apenas em duas das dez estrofes do poema. Nas outras estrofes, o alinhamento se faz de modo tradicional.

À parte dos recursos gráficos, o que chama a atenção numa primeira leitura de "Ciao Cadáver" é o número reduzido de conectores sintáticos, a escassez de verbos (há apenas um no poema inteiro) e a dominância dos elementos nominais. Outra característica é o uso de diversas línguas (há lexemas em inglês, francês, alemão, grego e latim), além de referências a diversas esferas da cultura humana (mitologia, linguística, medicina, pintura, música etc.), tornando a poesia bastante hermética.

A semiótica greimasiana sempre sofreu quando da tentativa de análise de textos não verbais, principalmente se estes não apresentassem figuras (como as pinturas abstratas, por exemplo), às quais, de um modo ou de outro, garantiriam o 
acesso à significação do texto. Porém, diante da poesia de Delmo Montenegro, algo novo se apresenta: a dificuldade de se acessar a significação não de uma pintura, ou de um gesto, mas de um texto verbal e, não obstante, repleto de figuras bastante concretas.

Para que possamos prosseguir a análise de "Ciao Cadáver" - o poema -, apresentaremos, primeiramente, um breve comentário sobre seu estilo de composição a partir do conceito tensivo de triagem, de Claude Zilberberg. Caminharemos, então, para a busca de isotopias no poema e seu percurso narrativo à luz da missividade.

\subsection{A poética do raro: triagem de palavras}

No texto "As condições semióticas da mestiçagem" (ZILBERBERG, 2004), Claude Zilberberg discorrerá acerca das práticas semióticas de triagem e mistura. Resumidamente, as operações de triagem e mistura seriam, respectivamente, um movimento de fechamento e abertura reguladores da entrada e saída de elementos. No processo de triagem teríamos, por meio de um regime de exclusão, a valorização daquilo que é raro, puro e exclusivo. Já no processo de mistura, numa operação de abertura e num regime de participação, seriam valorizados o numeroso, a expansão e o "misturado".

A partir de tais processos, acreditamos que seria possível sistematizar, ao menos, dois regimes estilísticos: um que valorizaria a triagem, um que valorizaria a mistura. No caso de Delmo Montenegro, acreditamos que seu estilo poético se 
aproxima da operação de triagem - uma triagem linguística. Assim como num quadro de Piet Mondrian ${ }^{13}$, em que pouquíssimos elementos pictóricos são utilizados para a composição de seus quadros (apenas cores primárias e traços retos), Montenegro tria a linguagem excluindo elementos como conectores sintáticos e verbos (em "Ciao cadáver, por exemplo, há apenas um), construindo uma poesia predominantemente nominal, sintética e hermética. Assim como Mondrian faz com a pintura, Delmo parece querer reduzir, limitar, decantar a linguagem, num peneirar de palavras estranho ao que costumamos nos deparar em poesias.

Em "Ciao cadáver", poema objeto de estudo em nosso texto, a primeira coisa a se notar é a quantidade de espaço em branco na mancha da página. O poema é composto de poucas palavras cuidadosamente selecionadas para exprimirem o máximo de conteúdo concentrado. Sem conexões sintáticas, tais palavras parecem

${ }^{13}$ Piet Mondrian (1872-1944) foi um artista holandês membro do movimento De Stijl ("O Estilo"). As telas de Mondrian são conhecidas por seu estilo minimalista de linhas retas e perpendiculares e o uso de apenas cores primárias para a composição de suas telas. Como em Composição 2, de 1922:

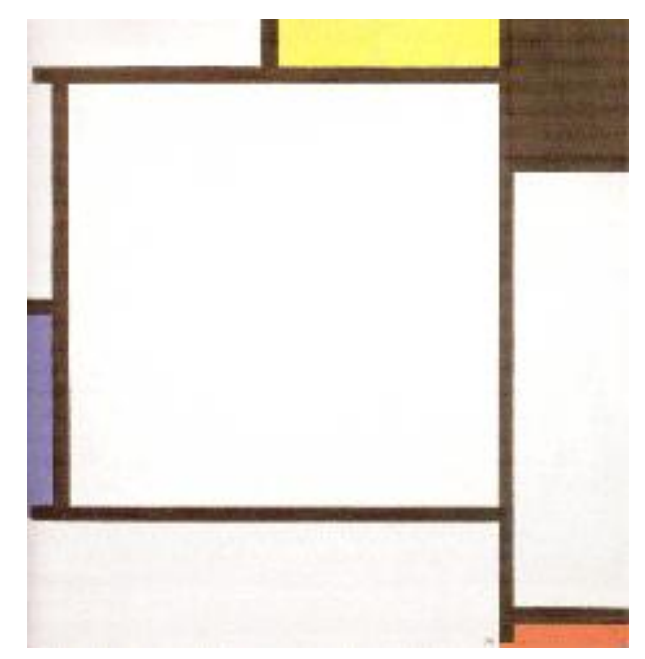

Como se pode observar, o estilo de Mondrian poderia ser definido como mais próximo do movimento de triagem, ou seja, seleção e controle de elementos. 
flutuar sem sentido frente aos nossos olhos. Digno de um quadro de Piet Mondrian, o poema nos oferece poucos recursos para sua interpretação. Tendo justificado a composição do poema por meio de um processo de triagem, prosseguiremos nossa análise em busca de dar sentido ao pincelar linguístico de Delmo Montenegro.

\section{2 "Ciao Cadáver", de Delmo Montenegro}

Devido à extensão do poema, optamos por alocá-lo em subtópico próprio. Vejamos:

\section{Ciao cadáver}

para Lourenço Mutarelli

luxo-caveira: divertissements

-necropsia

ludopédia

câncer

ludopédia

sífilis 
mandíbula- bistrot: vagina

$\operatorname{lux}$

potest: sangria

tudo sangra sob os estrobos

discopélvis

disclampsia

discohell

dance

terpsícore

dance 
(sala bossa-tripálio-lounge)

go

dance

(autopsia-pista

solilóquio-

câncer ）

entre sono insone

gozo-estrobo

cocaína-

elton john

: apnéia-resort

homo- 
shiatsu

: sauna

água câncer

suor

sob

suor

hokusai

song

achtung-esqueleto

achtung

cobra-caveira

(jaspe e bronze

traçados

dubuffet-crematório 
carne auschwitz

sub carne auschwitz

latão-ônix-pesadelo:

achtung-cara-de-cão

(língua-porco-

crematório:

arame-cabelo-

pasta de banha seca

língua-vômito-

assoalho: les illuminations )

gioconda verbii

metralha-

betume-concreto 
língua-cóccix

achtung-esqueleto

achtung

cobra-caveira

escultura

- tripálio

móbile

lingam 
(nekrosis-veronese)

purg-

expurg-

(ênclise-caos)

purg-

expurg-

câmera de eco ars

coprofagica

céu ainda não

hagios 
-metal larval

grito

bufonaria-viola-necrose:

canto-cão

lexicoma (displasia

de fones

costela de nomes

céu

céu

parabolar

oxímoro-canto-câncer)

grito 
hagios

-metal salamandra

fossa

de fezes

ciao

cadáver

ó

cristo-corte

ó

psalmo-psaltério

ó

anjo sal 
bovino-rembrandt:

pirâmede

fecal

ó

gozo-húmus

ó

fístula-diarréia

ó

citè-pavlov-câncer

: asno de ouro

meta-

phoréin 


\subsection{Acessando a significação: isotopias}

Diante de um poema predominantemente nominal, o primeiro passo de análise por nós preferido - e, talvez, o mais sensato - foi o da busca pelas isotopias. A esse ponto, é importante salientar a peculiaridade da análise de "Ciao cadáver" geralmente, ao se analisar um texto, sabemos, ainda que intuitivamente e sem sistematização, do que aquele texto fala; "Ciao cadáver", no entanto, se apresenta como um poema, à primeira vista, indecifrável, restando à análise nos guiar por sua significação. Assim, a busca pelas isotopias não foi uma forma de sistematizar um sentido já previamente assimilado, e sim a tentativa de sistematização do poema para que, de alguma forma, sua significação pudesse surgir, ainda que opaca, diante de nossos olhos.

Assim, de forma bastante escolar, fomos agrupando as palavras em, ao menos, três isotopias predominantes: a da balada/noite, a da morte/doença e a da redenção/purificação. De modo que o quadro de isotopias seria, resumidamente, o seguinte: 


\begin{tabular}{|c|c|c|}
\hline BALADA/ NOITE & MORTE/ DOENÇA & REDENÇÃO/ PURIFICAÇÃO \\
\hline luxo & necropsia & água \\
\hline divertissements & câncer & les illuminations \\
\hline ludopédia & sífilis & purg- \\
\hline lux potest & sangria & expurg- \\
\hline estrobos & discohell & hagios \\
\hline discopélvis & tripálio & céu \\
\hline disclampsia & autopsia & asno de ouro \\
\hline discohell & esqueleto & anjo \\
\hline dance & crematório & cristo \\
\hline Terpsícore & carne & \\
\hline lounge & Auschwitz & \\
\hline autopsia-pista & pesadelo & \\
\hline sono & nekrosis & \\
\hline insone & fossa & \\
\hline cocaína & cadáver & \\
\hline gozo & etc. & \\
\hline suor & & \\
\hline etc. & & \\
\hline
\end{tabular}

Figura 12 - Quadro das isotopias de "Ciao cadáver"

As figuras e sua organização em isotopias são sempre um bom recurso na busca pela significação de um objeto de análise opaco. No entanto, "Ciao Cadáver" 
ainda apresenta mais duas chaves interpretativas: sua dedicatória a Lourenço Mutarelli e a filiação poética.

Lourenço Mutarelli é um quadrinista (e, mais recentemente, também escritor) paulistano conhecido por seus desenhos e histórias sombrios e angustiantes. A fim de ilustrar um pouco de seu estilo, vejamos uma cena de Transubstanciação (1991) - uma de suas histórias em quadrinhos mais famosas:

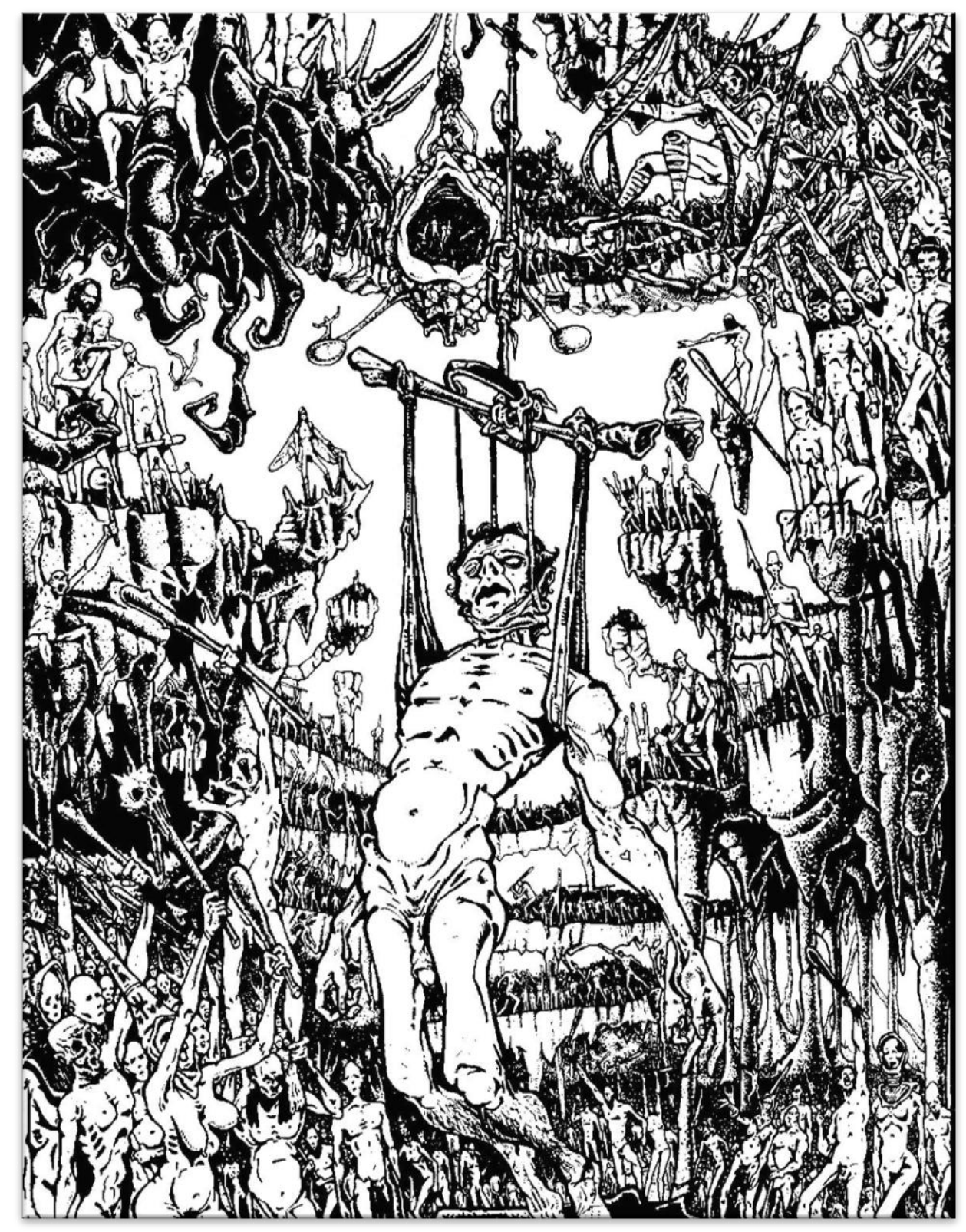

Figura 13 - Cena de Transubstanciação, de Lourenço Mutarelli 
Ao se analisar a cena em questão, temos um sujeito abatido - ou em transe sendo suspenso de um ambiente doentio, com características infernais e sombrias. Repentinamente, as isotopias antes selecionadas em "Ciao cadáver" de noite, doença e redenção parecem se encaixar também na ilustração de Mutarelli. Embora esclarecedora da dedicatória do poema, no entanto, apenas conhecer o estilo de Lourenço Mutarelli não nos dá a interpretação completa do poema.

A respeito de sua filiação poética - segunda chave interpretativa -, como já exposto, o poema se apresenta, no que diz respeito a sua estrutura, mais próximo ao fazer poético concreto. Como o sentido nasce da relação, uma boa forma de se resgatar o sentido de um texto é convocando outros textos com os quais aquele se relaciona.

Haroldo de Campos, poeta concreto paulistano, publicou, em 1979, Signantia quasi coelum - Signância quase céu, cuja última parte é composta pelo poema "Esboços para uma Nékuia" (Campos, 1979: 68). A partir dos primeiros versos é inegável a semelhança temática com "Ciao Cadáver":

O caos facetado

desço

até

tocar no

negros revérberos no negro luz negra pólem no escuro 
No decorrer de "Esboços para uma Nékuia", há isotopias de morte, de purificação, de inferno etc. Há, ainda, similitudes mais abstratas, como a noção de "descida" e "subida", presentes também em "Ciao Cadáver". Tais temas e direções são típicos da práxis de uma nékuia, definida como uma "descida aos infernos" capaz de, ao mesmo tempo em que decai o sujeito, fazê-lo ascender, numa espécie de purificação. Em “Esboços para uma Nékuia” (Campos, 1979: 97):

descer

para

subir

para

subir

descer

Portanto, aquelas isotopias que antes separávamos em três, na verdade, podem ser reduzidas a apenas duas: a da balada/noite e a do percurso da nékuia, a qual conjugaria as isotopias da morte/doença/inferno com a da redenção/purificação. 
Ou seja, conjugando a cena de Transubstanciação, de Lourenço Mutarelli, mais o poema de Haroldo de Campos pode-se, finalmente, entender a temática de "Ciao cadáver". O poema se constrói no sentido de ilustrar a ida de um sujeito a uma "balada" como uma nékuia: uma descida aos infernos. A respeito desse percurso, continuaremos nossa análise sob o ponto de vista da missividade.

\subsection{O percurso de uma nékuia: momento de remissividade}

Ao sistematizar as isotopias encontradas, não é difícil encontrar uma gradação lexical no sentido de algo disfórico que vai se transformando em algo eufórico. Ou seja, pensando numa nékuia como uma trajetória que "desce para subir" (uma parábola), poderíamos ilustrar o percurso isotópico-lexical de "Ciao cadáver" segundo tais coordenadas espaciais, chegando ao seguinte gráfico: 

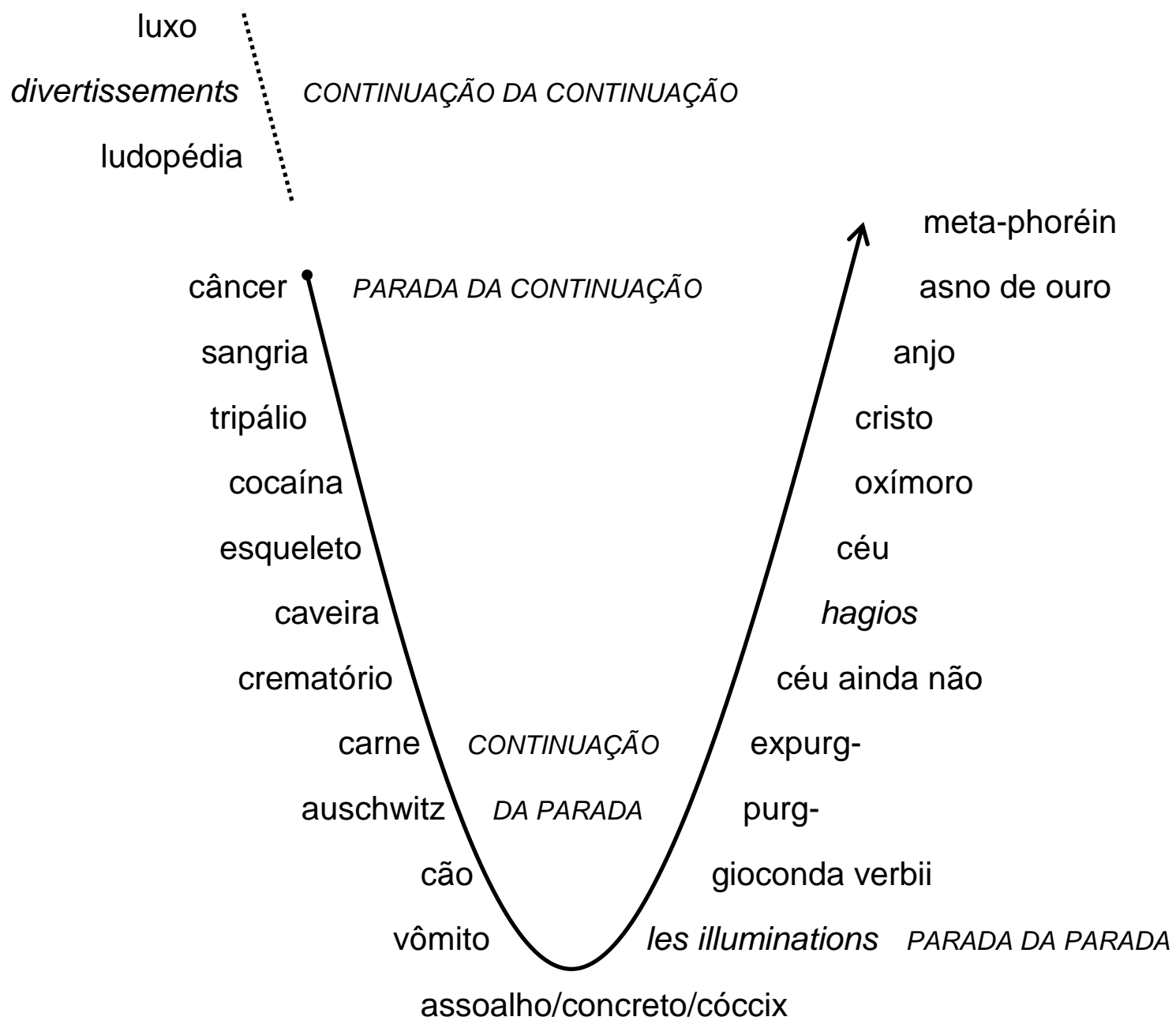

Figura 14 - Gráfico das isotopias de "Ciao cadáver"

A partir da representação acima, podemos chegar a um encaminhamento de análise bastante estruturado e esclarecedor. Pelos três primeiros lexemas da poesia - luxo, divertissements ${ }^{14}$ e ludopédia ${ }^{15}$ - define-se um sujeito em estado de continuação da continuação, ou seja, relaxado. Trata-se de valores emissivos - o programa narrativo do sujeito é o ir a uma "balada" e dançar, se divertir.

\footnotetext{
${ }^{14}$ s.m. Divertimento; intermédio de dança e canto (durante um intervalo no teatro.)

${ }^{15}$ lud(i)- el. comp. antepositivo, do latim ludus "jogo, divertimento, recreação" + ped(i)- el. comp. antepositivo, do latim pes, pedis "pé" (no sentido próprio ou figurado). Poderíamos definir ludopédia, literalmente, como "brincadeira com os pés" (embora saibamos que pode também se referir ao jogo de futebol, não nos parece ser essa a interpretação mais próxima à temática do poema).
} 
Logo em sequência, porém, temos a palavra "câncer", instituindo a parada da continuação, seguida pela continuação da parada figurativizada pelos lexemas de morte e doença - sangria, tripálio ${ }^{16}$, cocaína, esqueleto, crematório, carne, auschwitz, cão, vômito - exatamente até a quinta estrofe do poema. No último verso da quarta estrofe, o sujeito chega ao máximo da descida, figurativizado por "assoalho", "concreto", "cóccix" chegando também ao máximo da tensão. A partir daí, certo relaxamento começa a se dar. É instituída a parada da parada, surgindo, gradativamente, lexemas menos remissivos e ligados à descida e à morte e mais à purificação e à redenção: "les illuminations", "purg-"17, "expurg-"18, "hagios"19, "céu". É interessante observar que a subida está bastante explícita quando do verso "céu ainda não". E o máximo da purificação também está explicitado por meio da referência ao conto de Apuleio "O asno de Ouro" ${ }^{20}$, além de referências ao sagrado e celestial em "cristo" e "anjo".

Desse modo, "Ciao Cadáver" trata, superficialmente, da ida de um sujeito a uma balada/danceteria/discoteca o que não traz o relaxamento esperado ao sujeito, gerando grande tensão e convocando valores de remissividade. No entanto, essa "ida à balada" torna-se, miticamente, também uma descida aos infernos, uma

\footnotetext{
${ }^{16}$ Do latim tripalĭum "instrumento de tortura" (também origem da palavra "trabalho").

17 : el. comp. antepositivo, do v. lat. purgo "purificar, limpar (no sentido físico ou moral), purgar, justificar, desculpar"

18 1. Fazer purgar, limpar 2. eliminar a sujidade, tornar limpo 3. fig. livrar do que é pernicioso, deletério, imoral.

${ }^{19}$ Do grego hágios: "santo, sagrado".

${ }^{20}$ Obra de Apuleio (século II a.C.) que narra as histórias de Lúcio, um jovem transformado em asno por formas mágicas e que só vem a recuperar sua figura humana, meses depois, devorando uma grinalda de rosas consagrada à Deusa Ísis.
} 
nékuia. O sujeito desce aos infernos e retorna purificado naquele espaço e tempo práticos do evento noturno.

\subsection{Considerações finais}

Do ponto de vista da missividade, como demonstramos pela distribuição figurativa, o poema se apresenta, em sua maior parte, no momento da parada e de sua continuação, ou seja, a poesia convoca valores extremamente remissivos: cronopoiese, criação de um tempo figural insuportável ao sujeito, e fechamento do espaço, figurativizado, inclusive, pelo próprio confinamento do ator da casa noturna. A remissividade também explica a escassez de verbos e a profusão de substantivos na construção do poema: tratando-se a remissividade de um anti-programa, essa se configura, portanto, como a parada do programa, ou seja, é uma parada na ação do sujeito. Segundo Zilberberg (2006: 137), é próprio do fazer remissivo concentrar, nominalizar e modalizar.

É interessante observar que, sem recorrer à interdiscursividade existente entre a poesia de Delmo e a de Haroldo de Campos e ainda ao estilo de Lourenço Mutarelli, o percurso da nékuia se tornaria átono e apenas virtualizado, enquanto o da balada/noite seria o realizado. A partir do conhecimento dessa relação, no entanto, é possível exercer uma interpretação da poesia de maneira mais tônica, de modo que a isotopia da balada está atualizada e a da nékuia potencializada (Fontanille, 2001, p. 179).

Concluindo, a semiótica tensiva e a missividade mostram-se bastante eficazes inclusive na análise de textos de sentido opacos, tornando o acesso à significação não apenas satisfatório como produtivo e acurado. Diante da noção 
abstrata de "algo que para" (remissivo) e "algo que continua" (emissivo), pudemos direcionar a narrativa do poema, chegando, também por meio das isotopias selecionadas, a uma análise estruturada de "Ciao cadáver". 


\section{ANÁLISE DE MACISTE NO INFERNO (RACONTO), DE VALÊNCIO XAVIER}

Valêncio Xavier Niculitcheff nasceu em São Paulo (SP), no dia 21 de março de 1933, passando a viver em Curitiba (PR) a partir de 1954, cidade em que faleceu, aos 75 anos de idade, no dia 5 de dezembro de 2008. Além de escritor, Xavier foi cineasta conceituado, tendo recebido prêmios como o da IX Jornada Brasileira de curta-metragem de melhor filme de ficção por Caro Signore Feline. Xavier também escreveu para vários jornais e revistas, trabalhou na TV Paranaense (hoje RPC TV) e na TV Paraná (da rede Tupi), escreveu dramas para a televisão e chegou a dirigir episódios do Globo Repórter. Criou a Cinemateca do Museu Guido Viaro em 1975 que se tornaria a Cinemateca de Curitiba 23 anos mais tarde -, espaço responsável pela formação de vários cineastas paranaenses, identificados como a Geração Cinemateca, da qual fazem parte Carminatti, Fernando Severo e Berenice Mendes.

Xavier conheceu o sucesso de crítica e de público no final dos anos 1990, quando teve parte de sua obra publicada pela Companhia das Letras, depois de uma indicação da crítica literária Flora Süssekind,ganhando projeção nacional ao ser elogiado pelo escritor Décio Pignatari.

Maciste no inferno (raconto), de Valêncio Xavier, trata-se de um dos cinco livros do autor reunidos em O mez da grippe e outros livros (1998) - publicação da Cia. Das Letras ganhadora do Prêmio Jabuti de melhor produção editorial em 1999. No entanto, sua publicação original (hoje em dia, raríssima) foi em 1983, pela editora Criar, em Curitiba. 
Maciste no inferno (raconto) se apresenta como um "recontar" do famoso filme em preto e branco, dirigido por Guido Brignone, Maciste all'inferno, de 1926 . O filme trata da história de Maciste - personagem recorrente no cinema italiano, representando um homem mitológico de força descomunal, parecido com Hércules, capaz de grandes feitos heróicos - o qual decide viajar ao inferno em busca de uma criança sequestrada pelo diabo. Suas ações acabam por levá-lo a uma confrontação direta com Satã, o qual o condena à eternidade no inferno. Transformado em demônio, Maciste então luta para voltar a sua forma humana e escapar de sua maldição.

No entanto, mais do que um recontar, em Maciste no inferno (raconto), o filme é projetado como num cinema, sendo pano de fundo para o desenvolvimento de outra narrativa: a de um sujeito em busca de satisfação sexual. Tendo como característica principal o abuso de imagens e recursos gráficos, além de aproveitamento inusitado da mancha da página e linguagem peculiar (repleta de arcaísmos e, muitas vezes, sem a utilização de pontuação), a prosa de Xavier consegue, de fato, criar uma sala de projeção em seu livro.

A proposta de nosso capítulo é a de analisar Maciste no inferno (raconto) no que diz respeito, principalmente, à percepção. Desse modo, trataremos do processo de focalização e apreensão. Primeiramente, no entanto, buscaremos dar uma breve explanação a respeito do estilo de Valêncio Xavier e, ainda, empreender um breve resumo do livro. 


\subsection{Uma prosa da mistura}

Como comentado anteriormente, a prosa de Valêncio Xavier tem como elemento recorrente o sincretismo de linguagens. Dessa forma, na maioria de seus livros e contos, ilustrações e imagens dos mais diversos tipos podem ser encontradas. Em o Mez da grippe (1981), por exemplo, Xavier constrói a narrativa inteira por meio de notícias de jornais, propagandas, fotos e ilustrações - não existe texto proveniente de outra fonte que não essas. Ou seja, é muito importante frisar que as imagens presentes nos textos de Xavier não funcionam como ilustrações que redundam ou ratificam aquilo que está sendo narrado, e sim participam ativamente no processo de significação, diversas vezes sendo as únicas responsáveis pela narrativa.

Como já tratado em nossa análise de "Ciao cadáver", consideramos que os conceitos tensivos de triagem e mistura poderiam funcionar como processos de estilo. Ou seja, seria possível classificar um estilo literário, por exemplo, como mais próximo da triagem - selecionando e delimitando a entrada de elementos em busca do raro, do puro - e outro como mais próximo do processo de mistura - o qual valorizaria o numeroso, o variado, o "misturado", num processo de abertura.

A prosa de Valêncio Xavier, tendo como principal característica o sincretismo de linguagens, estaria mais próxima de um estilo operado pela mistura. Assim, se antes comparávamos a poesia de Delmo Montenegro aos quadros de Piet Mondrian, 
os textos de Xavier poderiam ser comparados a quadros de Jackson Pollock ${ }^{21}$ : mistura de tintas, objetos, processos de composição.

Em Maciste no inferno (raconto), a mistura parece permear todos os níveis de composição do texto. A primeira mistura é narrativa: duas narrativas correm em paralelo, a do filme (que se "autonarra"), e a do sujeito que vai assistir ao filme. Cada narrativa é marcada graficamente de forma diferente - quando da narrativa do filme, a fonte é "arial" em itálico; quando da do sujeito que assiste ao filme, a fonte é "times new roman" (XAVIER, 2002, p.95):

21 Jackson Pollock (1912-1952) foi um pintor americano conhecido principalmente pela sua técnica
inusitada de pintura chamada dripping, o que consiste em, ao invés de usar o pincel para desferir
pinceladas, usá-lo para gotejar, espirrar e borrifar tinta, de modo a não encostá-lo na tela. Além de tal
processo, as pinturas de Pollock conjugavam diversos materiais inusitados à pintura, como tachas,
terra, pregos e diversos outros materiais que o artista achasse conveniente participar de sua tela. Um
exemplo seria Autmn Rhythm (Number 30 ), de 1950:

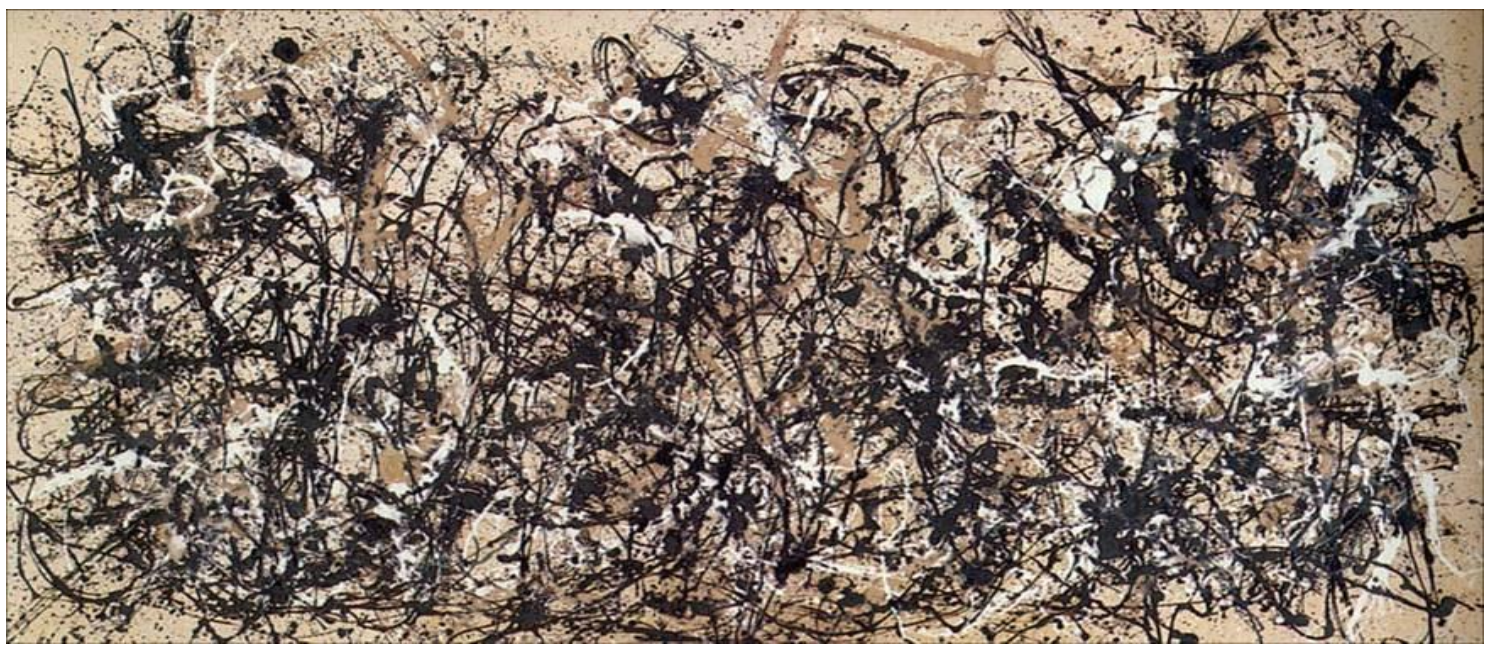

Observando tal pintura, podemos retomar o conceito tensivo de mistura e triagem e reiterar como o estilo de Pollock de fato se aproximaria do movimento de mistura, num processo de abertura e variedade de elementos. 


\section{Negro como o inferno até acostumar a vista} fico em pé as mãos na mureta de madeira que separa as fileiras de cadeiras da grande porta com cortinas de velludo que separa a salla de exibiçóes da salla de espera Este vendo Graziella seduzida por um conquistador sem escrupulos percebe a intervenção de Barbadilha e, ousadamente, trava renhida lucta com o demônio que o arrasta para o inferno

Figura 15 - página 13 de Maciste no Inferno (raconto)

A segunda mistura se deve ao fato de imagens - supostos fotogramas do filme - e texto verbal se alternarem ao longo das páginas. No entanto, imagem e texto verbal nunca ocupam a mesma página, criando uma espécie de ritmo de leitura bastante interessante. Outro fato a se observar é que, nas primeiras seis páginas do livro - correspondendo ao sujeito fora do espaço do cinema - o verso das páginas é branco; no entanto, a partir da sétima página - momento que corresponde à entrada do sujeito na sala de exibição - o verso das páginas é cinza. Dessa forma, ao se ler a história, tem-se, à esquerda, uma página inteira cinza e, à direita, ou uma página de texto verbal, ou um fotograma do filme. Tal recurso visual é capaz de recriar a própria iluminação do cinema, pois aquela página cinza à esquerda imprime escuridão ao texto.

Outro tipo de mistura que podemos identificar, a partir do trecho em destaque, é a falta de qualquer pontuação. Nesse sentido, a mistura se dá no nível da frase - 
sem o recurso da pontuação, diversas ambiguidades sintáticas não são resolvidas e as palavras, sem a contenção gráfica, flutuam pelos períodos.

Além dessas três misturas, haveria ainda uma mais sutil: apesar das personagens se manterem basicamente as mesmas do filme que se pretende recontar - Maciste allinferno -, os fotogramas não estão exatamente na mesma ordem do filme, tendo o autor adiantado ou atrasado certas cenas, além, obviamente, de ter cortado muitas outras já que o filme em questão, durando aproximadamente uma hora e meia, seria composto de centenas de fotogramas. Desse modo, o autor teria produzido uma espécie de "bricolagem imagética" com o intuito de simular a projeção do filme de 1926.

\subsection{Maciste no inferno (raconto): breve resumo}

Para que se possa empreender a análise a seguir, achamos importante que se faça um breve resumo de Maciste no inferno. O livro se inicia com o seguinte texto no centro da página (XAVIER, 2002, p.83): 


\section{Noite de Amor...}

Vertigem de Luxo...

Caminho da Perdição...

Gigolô...

Rouge e Pó de Arroz...

Perdida em Paris...

Os Mysterios de Hollywood...

Bachanal...

Sodoma e Gomorra...

Três Noites de D. Juan...

Macho e Femea...

Maciste no Inferno...

Figura 16 - página 1 de Maciste no Inferno (raconto)

Noite de Amor, Vertigem de Luxo, Caminho da Perdição etc., mais adiante no livro, entende-se se tratar de títulos dos filmes que estão (ou estarão) em exibição no cinema - espaço em que a história se passa. Ou seja, o que nos apresenta é um sujeito, ainda subentendido, que lê as futuras atrações do cinema em que está prestes a entrar.

Na terceira página, há uma foto com seis mulheres seminuas, sem qualquer texto. Na quinta página, encontramos os seguintes dizeres: 


\author{
“Columnas, templo, quadrigas, bastilhas de \\ papeláo, cavalleiros da Idade Média, \\ D'artagnans de fancaria, annuncios \\ luminosos, projectores, lampadas, lettreiros, \\ caretas, diálogos, versos, chronicas, \\ commentarios, apreciaçóes, taboletas nos \\ bondes e nos automóveis; latagões de feira \\ com estandarte e bandas de músicas; \\ coxas nuas de girls macias, meninas cobras \\ deitadas sobre areias, mulheres velludo \\ em atitudes lascivas sobre leitos ou dentro de \\ alcovas, mãos que agarram, lábios que \\ procuram, femeas que se entregam, corpos \\ em crispaçóes, oscullos infinitos, desejos, \\ ancias, fremitos, espasmos..."
}

Figura 17 - página 5 de Maciste no Inferno (raconto)

Tal texto, à primeira vista caótico, diz respeito à tematização e figurativização dos filmes a serem apresentados - "columnas", "bastilhas de papelão", "cavalleiros da Idade Média", "D'artagnans de fancaria" etc - e também à espacialização do cenário em que se passará a narrativa, o cinema - "anuncios luminosos", "projectores", "lâmpadas", "lettreiros", "diálogos" etc. No final do parágrafo, também é possível perceber certa isotopia sexual associada aos filmes e ao cinema: "coxas nuas de girls macias, meninas cobras deitadas sobre areias, mulheres velludo em atitudes lascivas sobre leitos ou dentro de alcovas, mãos que agarram, lábios que procuram, femeas, que se entregam, corpos em crispações, oscullos infinitos, desejos, anciãs, frêmitos, espasmos..." 
Seguindo essa espacialização, chegamos à sétima página do livro, a qual traz o fotograma de um homem alto ao lado de uma mulher e um rapaz. A seguir, à esquerda do leitor, a página já se apresenta cinza e o que temos, à direita, é o início da narrativa do filme. A essa altura, o sujeito está entrando na sessão de cinema. As páginas da esquerda se seguem cinzas e, posteriormente ao fotograma da quinta página, se segue uma página com uma espécie de partitura musical. Ou seja, assim que o sujeito entra na sala do cinema, tem contato com os dois elementos principais do filme: a imagem (representada pelo fotograma) e o som (representado pela partitura musical).

É, então, na página 13, que, finalmente, o sujeito aparece debreado enunciativamente:

Negro como o inferno até acostumar a vista fico em pé as mãos na mureta de madeira que separa as fileiras de cadeiras da grande porta com cortinas de velludo que separa a salla de exibiçóes da salla de espera

Este vendo Graziella seduzida por um conquistador sem escrupulos percebe a intervenção de Barbadilha e, ousadamente, trava renhida lucta com o demônio que o arrasta para o inferno

Figura 18 - página 13 de Maciste no Inferno (raconto) 
A cena que se apresenta em tal página é a do sujeito em pé na sala de cinema com o filme já iniciado: daí a escuridão em que ele se encontra ("Negro como o inferno") e o trecho em arial, correspondendo ao que se passa no filme em projeção. É na página 17 que, então, a busca do sujeito é revelada:

Com a luz que vem da tella busco com os olhos aquillo que quero e busco meu logar a mulher Até me assegurar que é uma mulher fico atraz da mureta de madeira as mãos segurando suas bordas Para que os outros espectadores não se apercebam das minhas intenções finjo entrar na fileira de traz com mais gente; mudo de idéia e entro na fileira da frente ameaço sentar numa cadeira vazia mas sento-me ao lado della É uma mulher

Figura 19 - página 17 de Maciste no Inferno (raconto)

A busca do sujeito é, aparentemente, por uma mulher: "Com a luz que vem da tella busco com os olhos aquillo que quero e busco meu logar a mulher". Nas páginas que se seguem, é descrito o contato do sujeito com seu objeto de desejo, a mulher (XAVIER, 2002: 103-115): 
É uma mulher Fingindo attenção na tella com o rabo dos olhos olho com coragem viro um pouco, bem pouco, a cabeça para que ella não perceba que estou olhando a clla Nem tentei encostar meu braço no seu e ella olha a tella tremeluz

Figura 20 - página 21 de Maciste no Inferno (raconto)

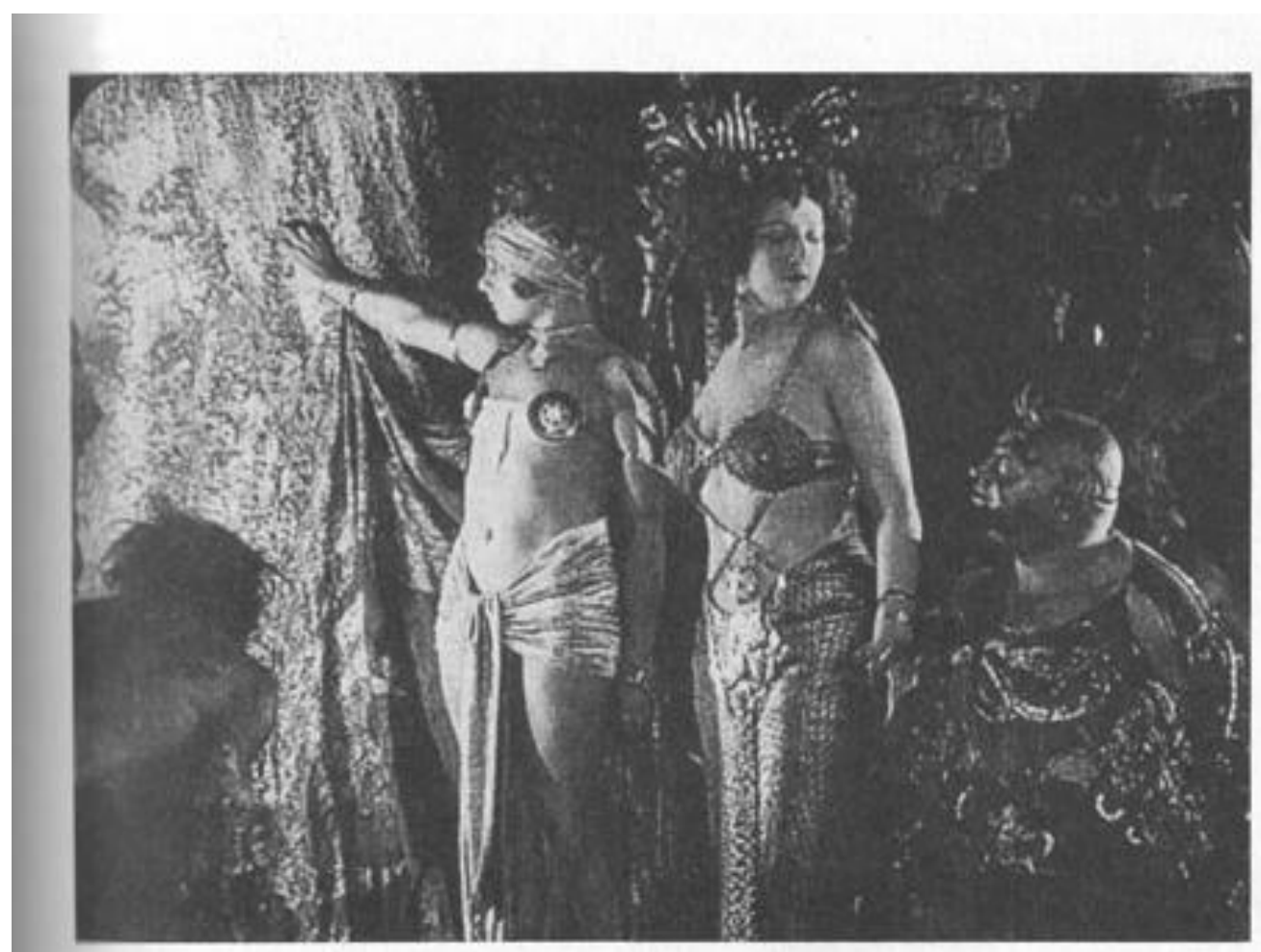

Figura 21 - página 23 de Maciste no Inferno (raconto) 
Ora o mortal que chega ao inferno sem ter morrido, pode voltar ao mundo se ao fim de trez dias não tiver cedido à tentação de alguma beldade d'aquelle antro

É bella e macia, estou com meus braços cruzados e as pontas dos meus dedos acariciam o fino tecido de sua blusa solta ella nấo solta os olhos da tella cintilante nem sente minha caricia na seda macia diferente do áspero velludo das vermelhas cortinas É um filme marron nas cennas de inferno é vermelho Um calor me sobe por todo meu corpo, frieza da seda

Ora, Proserpina, a esposa própria de Plutão tenta-o com encantos taes que Maciste ousa beijal-a: Estava decretada sua sentença às pennas etternaes

Figura 22 - página 25 de Maciste no Inferno (raconto) 


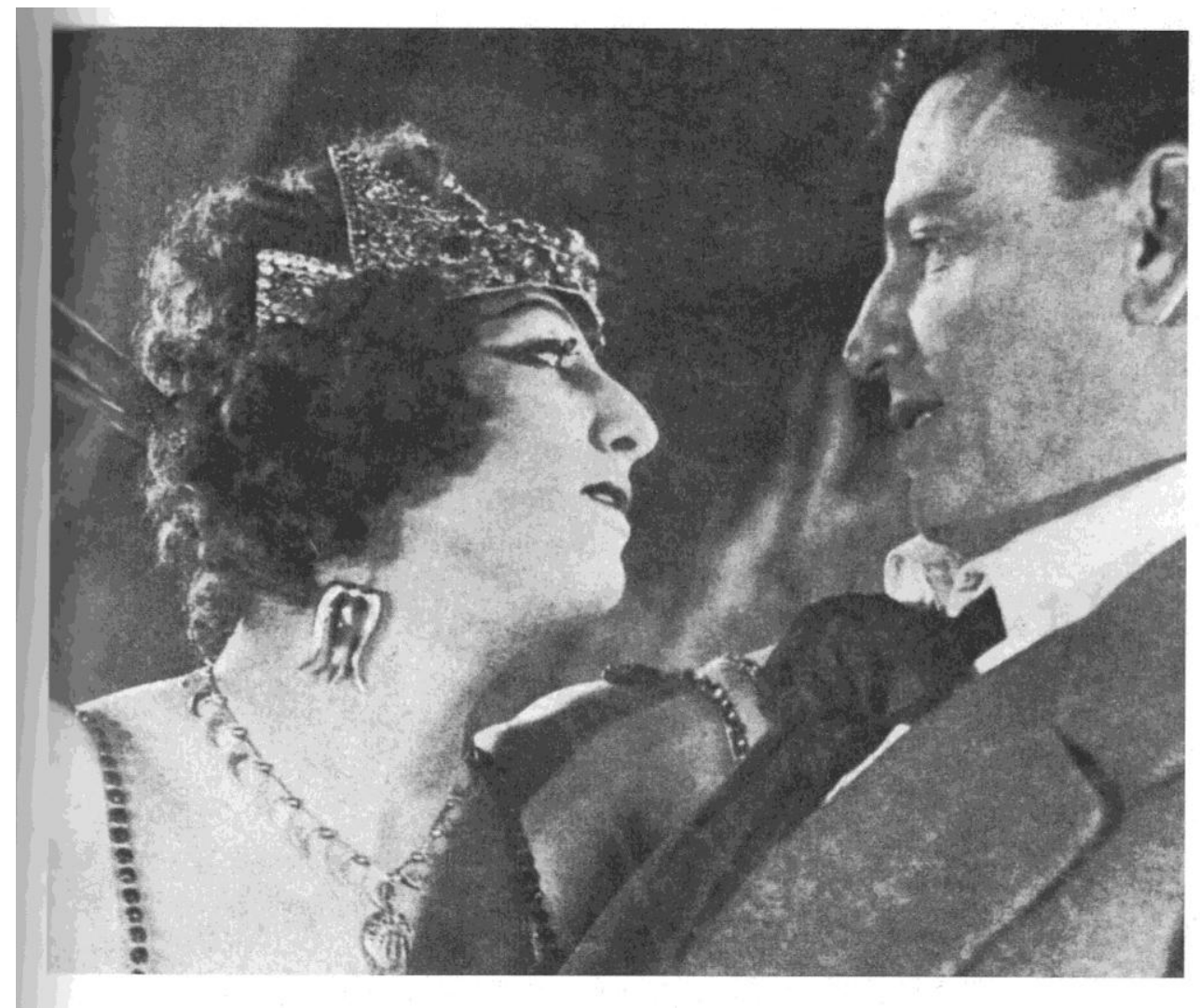

Figura 23 - página 27 de Maciste no Inferno (raconto)

Ouso, empurro meus dedos tremulos e toco seu braço como se fosse sem querer Náo sobre a cadeira ao lado meu chapeu esta assentado sobre meu sexo agora zona de calor Ella afasta seu braço Ouso, insisto ella afasta seu braço vira-se e olha firme para mim meus olhos estáo na tella

Figura 24 - página 29 de Maciste no Inferno (raconto) 


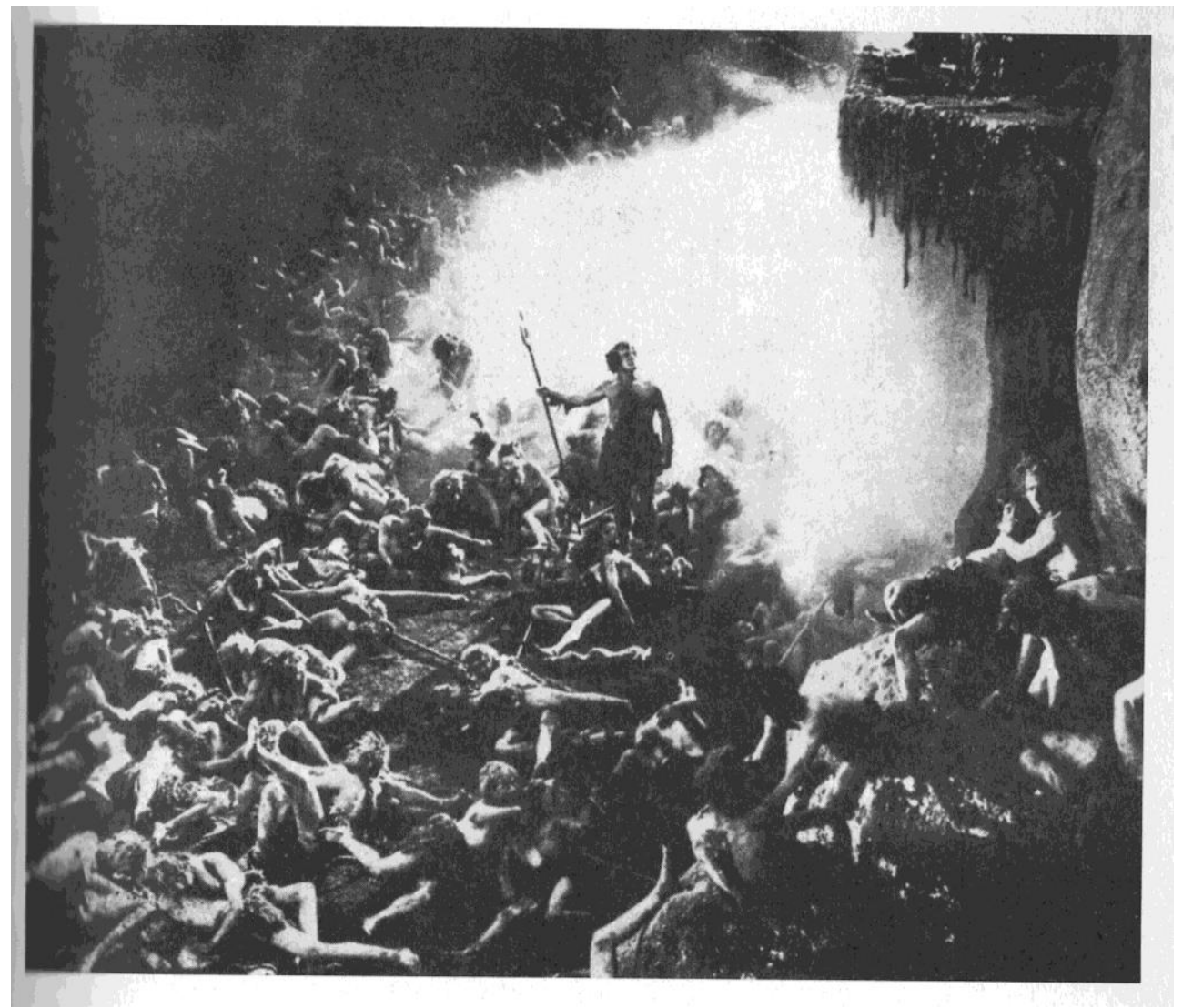

Figura 25 - página 31 de Maciste no Inferno (raconto) 


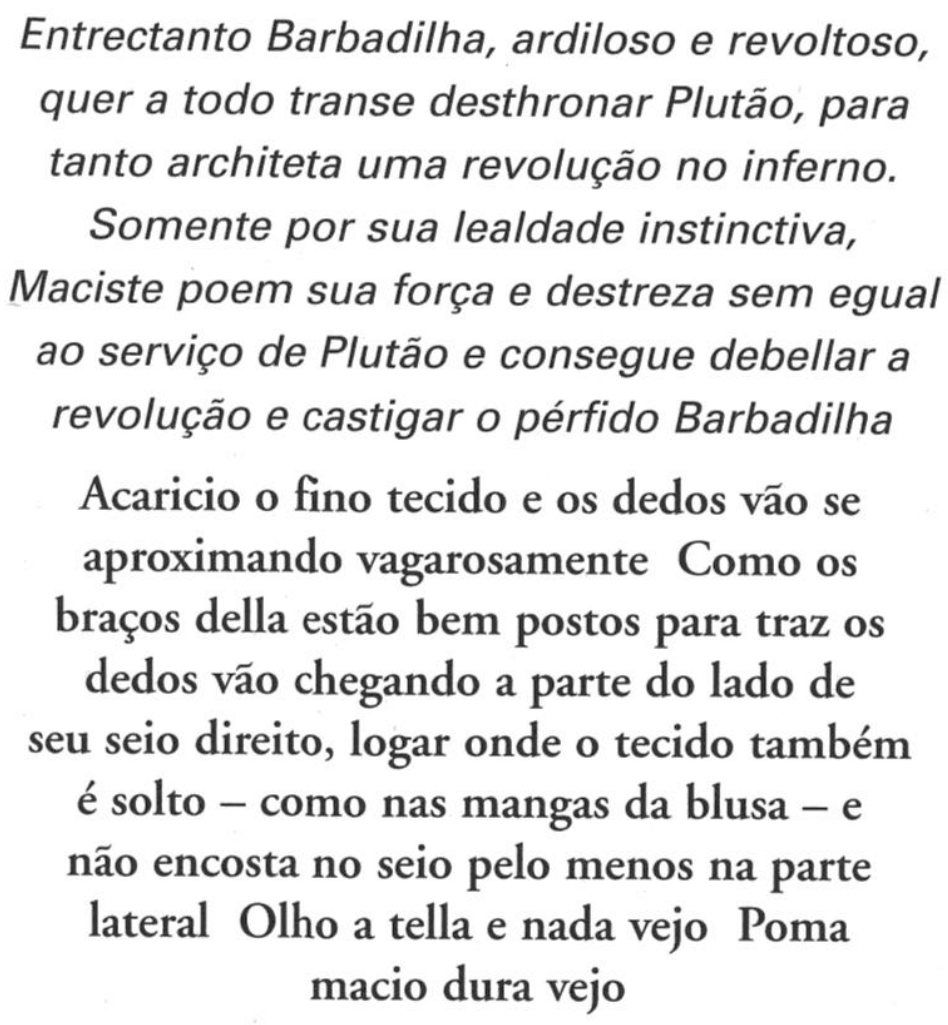

Figura 26 - página 33 de Maciste no Inferno (raconto)

A cena que se desenrola ao longo de tais páginas é a do sujeito que busca certo contato físico com a mulher sentada ao seu lado. Tal contato é extremamente gradativo - um toque de leve em seu braço, um roçar de dedos em sua blusa... É importante frisar que, em nenhum momento, há troca de olhares entre os dois. A movimentação toda é feita com a intenção de se passar despercebido, assim, ao menor sinal de possível reação da mulher ao seu toque, o sujeito lança o olhar na tela do cinema, dissimulado.

Ao passo em que o sujeito vai conseguindo se aproximar da mulher, sua excitação sexual vai ficando clara: menciona-se o calor que the sobe o corpo; o chapéu que cobre seu sexo (provavelmente, ereto) e, finalmente, a iminência do 
gozo é descrita - "Olho a tella e nada vejo Poma macio dura vejo". A seguir, dois fotogramas são apresentados e o gozo é narrado (XAVIER, 2002, p.117-121):

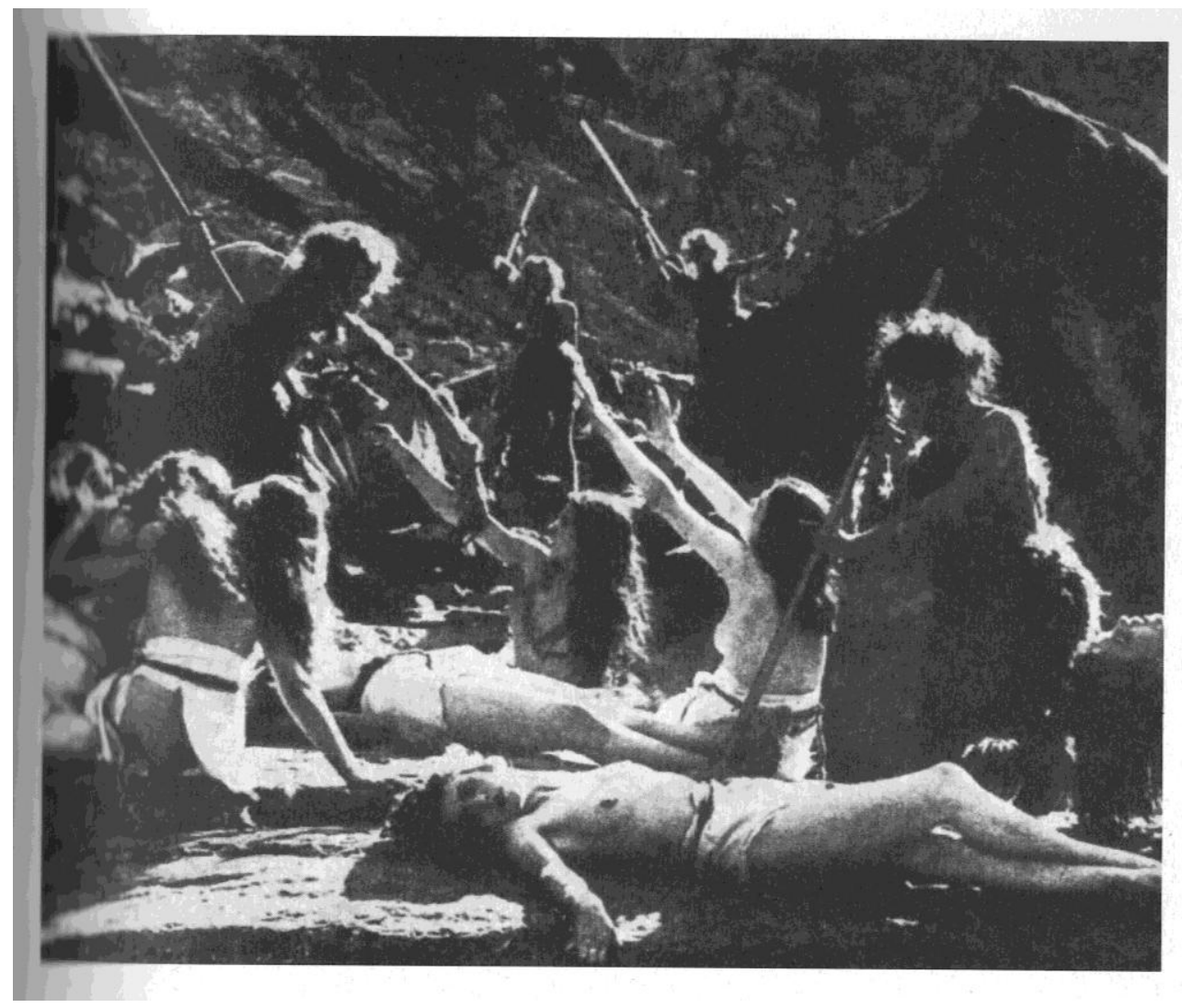

Figura 27 - página 35 de Maciste no Inferno (raconto) 


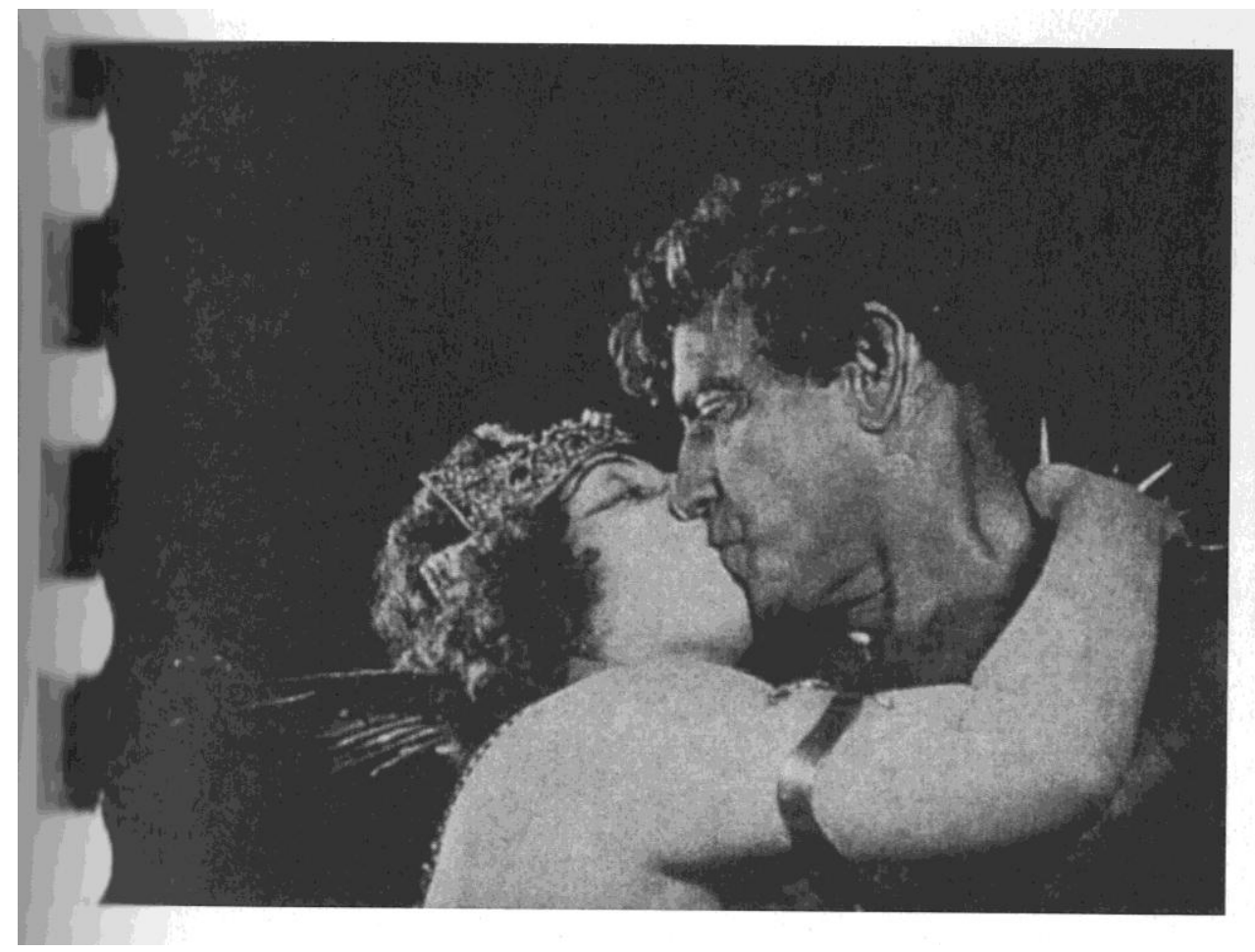

Figura 28 - página 37 de Maciste no Inferno (raconto) 


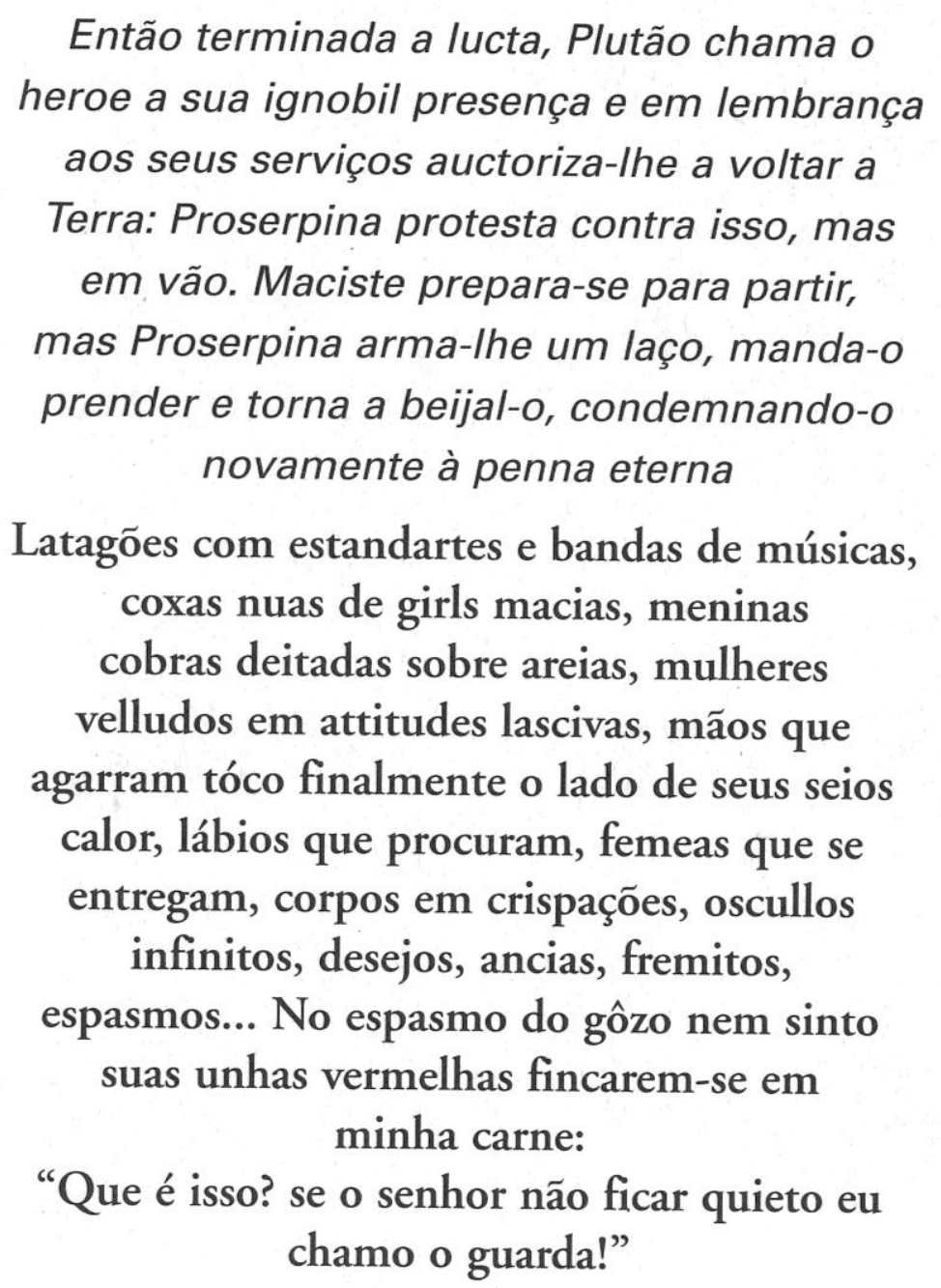

Figura 29 - página 39 de Maciste no Inferno (raconto)

A cena do gozo é descrita, inicialmente, como o texto que se apresenta na quinta página do livro, porém, entremeado pela descrição do que se passa: o toque nos seios e o espasmo de seu gozo. Se voltarmos à página 5 do livro, veremos que tal trecho se encontra entre aspas. Uma interpretação, então, poderia ser feita - a de que, naquele momento de entrada no cinema, o sujeito se lembra de gozos passados, o que faria essa sua busca pelo prazer algo recorrente.

Durante o gozo do sujeito, algo inesperado ocorre: a mulher, sentada ao seu lado, finca-lhe a unha, ameaçando desmascará-lo. Imediatamente, e ainda sem 
trocar olhares com a mulher, o sujeito se levanta e, disfarçando, vai até o banheiro, se limpa, e sai do cinema (não sem antes checar as próximas fitas a serem exibidas) rapidamente (XAVIER, 2002, p.123-135):

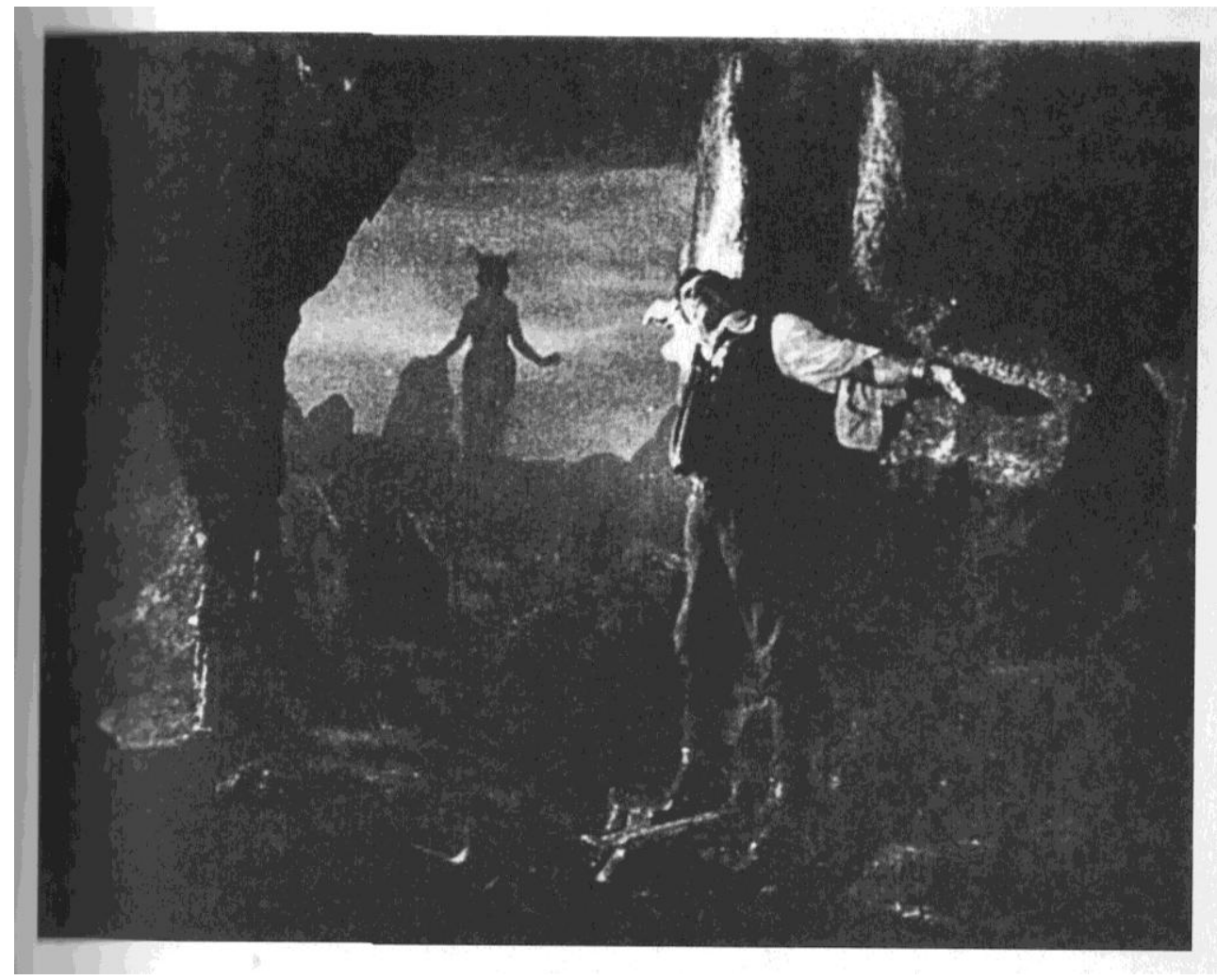

Figura 30 - página 41 de Maciste no Inferno (raconto) 
Levanto sem olhar saindo pelo outro lado das cadeiras Disfarço sair agora sem o filme acabar chamaria atenção; por isso dirijo-me ao banheiro Letreiros homens pintado num vidro que a luz vermelha alumia Uma pequena cortina vermelha antes da porta impede que abrindo a porta a meia luz do logar chegue na salla de projeção Evito olhar no espelho não há toalha limpo a mim e a calça como posso com o papel do programa que anuncia as próximas fitas Caminho da Perdição... As Trez Noites de D. Juan... Macho e Femea... Sodoma e Gomorra...

Entrectanto, na Terra, o seductor de Graziella arrependido de seu acto, volta para junto d'ella e seu filho, que já tem então um anno e meio de edade. Na véspera do Natal,

Figura 31 - página 43 de Maciste no Inferno (raconto) 


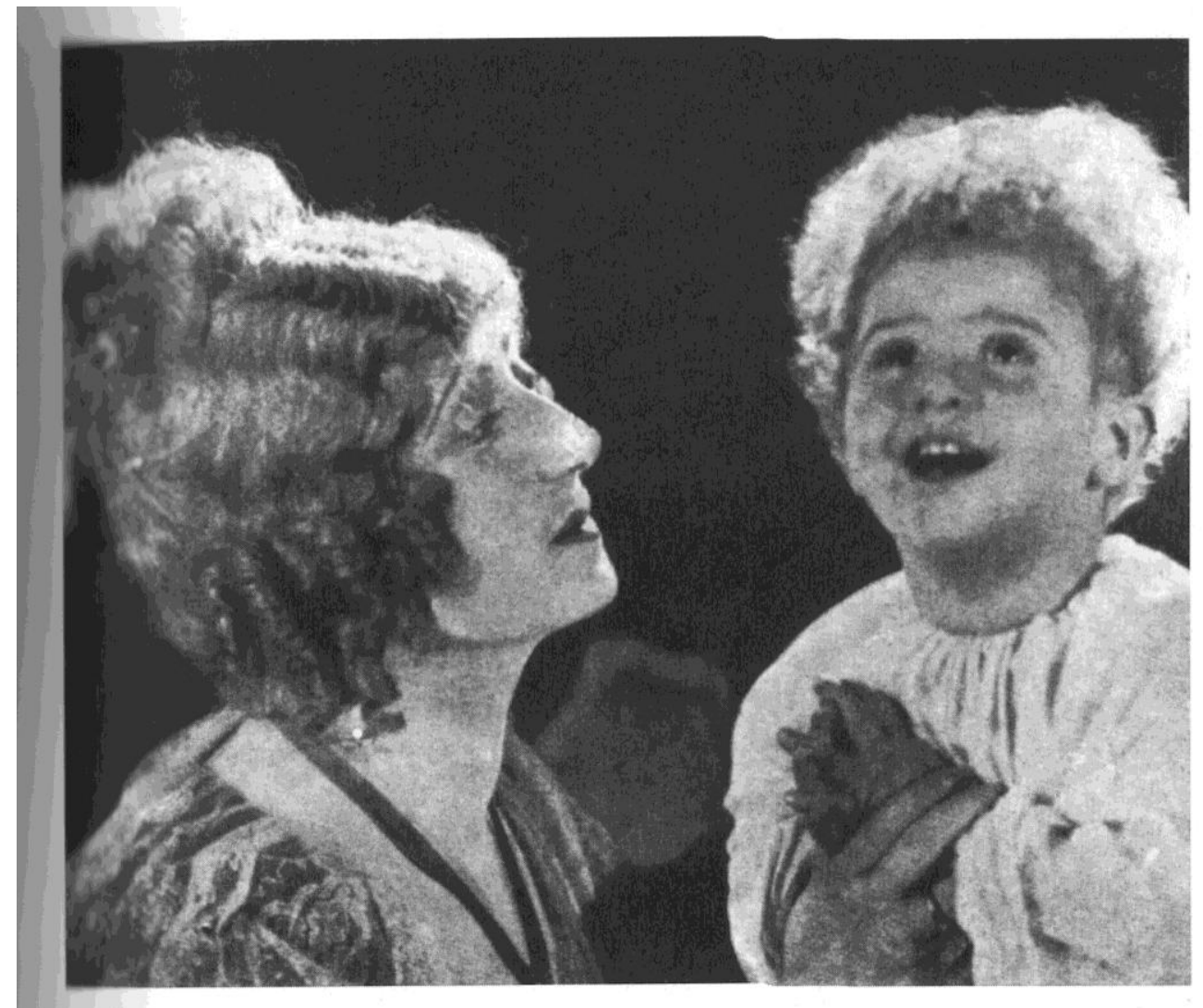

Figura 32 - página 45 de Maciste no Inferno (raconto)

Graziella faz esta adorável creança rezar por seu protector, o impávido collosso Maciste e dá-se o milagre: a prece infantil é ouvida e o Todo Poderoso liberta Maciste e este volta à Terra para gozar a ventura de um novo lar, entre seus amigos

Não posso ficar neste logar muito tempo chamaria a attenção sobre minha pessoa $\mathrm{A}$ fita está acabando apresso-me com o chapeu cubro a mancha úmida de minha calça as gentes da salla de espera me olham sou o primeiro a sair

Figura 33 - página 47 de Maciste no Inferno (raconto) 


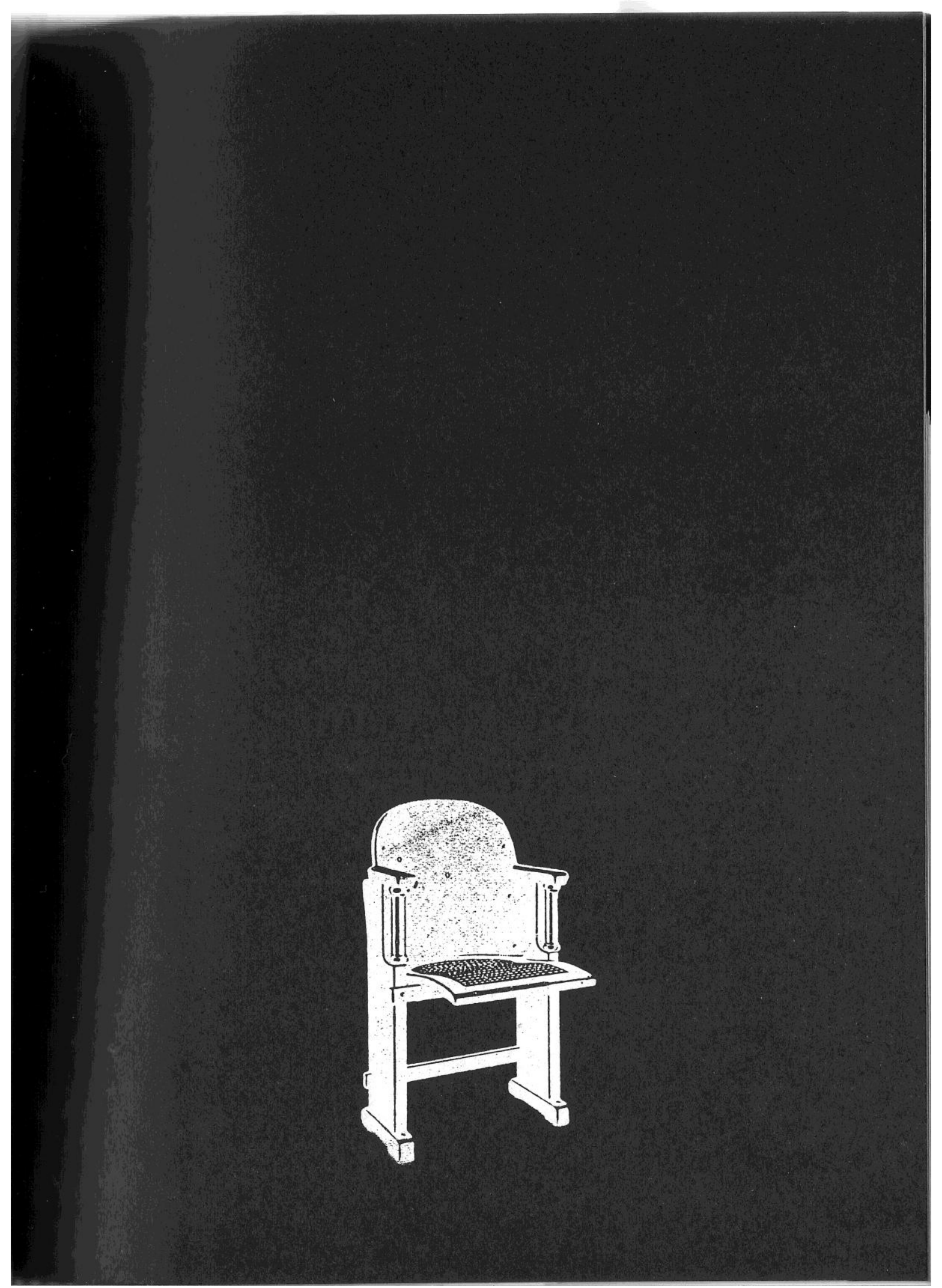

Figura 34 - página 49 de Maciste no Inferno (raconto) 
Mesmo a luz mortiça das quatro horas da tarde me cega Já não escuto o piano quando todos começam a sair da sessão já estou escutando o barulho da cidade das casas das vozes dos automóveis dos ruidos

Sou novamente parte da cidade e ninguém me vê

Figura 35 - página 51 de Maciste no Inferno (raconto)

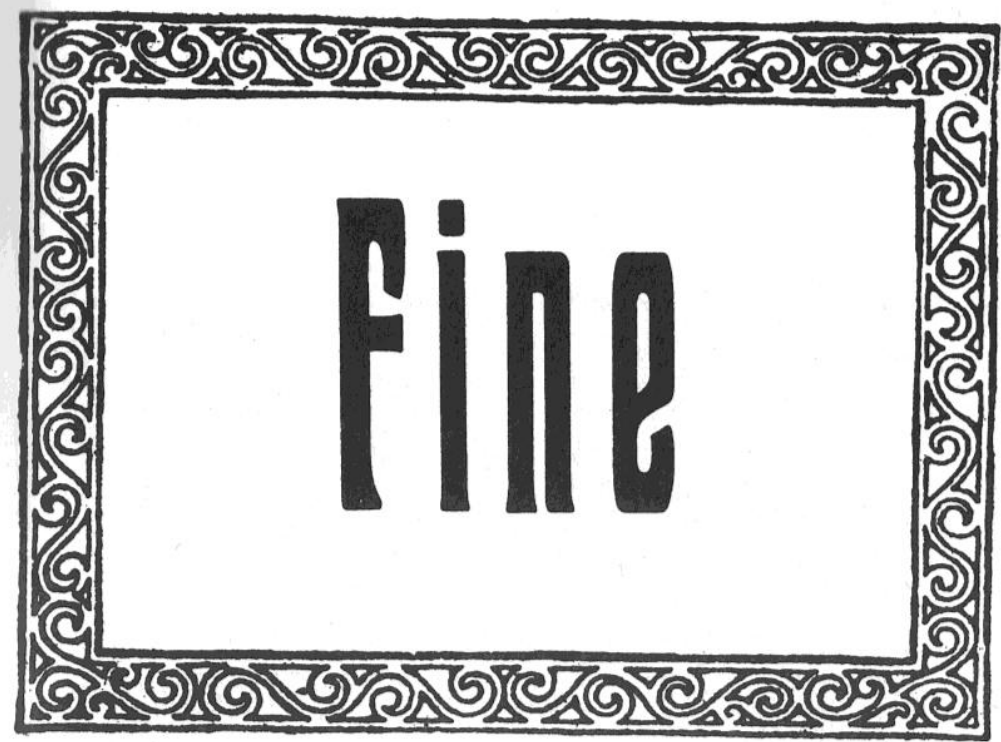

Figura 36 - página 53 de Maciste no Inferno (raconto)

A partir do desfecho da história, podemos inferir que a mulher funciona para o homem como um adjuvante em sua busca pelo prazer. Desse modo, assim que a mulher se faz sujeito, tendo voz e agindo, desconcerta o homem, o qual, atordoado, 
tem que sair do cinema rapidamente, de modo a não ser desmascarada a sua perversão.

Feito esse rápido resumo da trama do livro, partamos para sua análise.

\subsection{A busca: apreensão e focalização}

Devido à relação peculiar existente entre o sujeito e a mulher em Maciste no Inferno (raconto), optamos por conduzir nossa análise a partir da noção da presença. Ou seja, sob o ponto de vista da percepção.

Em Tensão e Significação (2001), Fontanille e Zilberberg atrelam a problemática da presença à da enunciação. Desse modo, a presença seria controlada pelos mesmos elementos da enunciação: actante, espaço e tempo. Dizem os autores (2001, p.124-125):

Nosso ponto de partida estará constituído pela pressuposição recíproca entre, por um lado, o "campo de presença", considerado como o domínio espaço-temporal em que se exerce a percepção, e, por outro, as entradas, as estadas, as saídas e os retornos que, ao mesmo tempo, a ele devem seu valor e lhe dão corpo.

Do ponto de vista do actante, considerado em sua relação com o objeto, a presença seria apreendida ou como espanto e novidade, ou como hábito e antiguidade. Já na dêixis espacial, regulada pela categoria tensiva da profundidade, a presença realizada seria da ordem do próximo, enquanto a presença virtualizada, do distante. Do ponto de vista temporal, o atual manifestaria a presença realizada e o ultrapassado, a virtualizada. 
A percepção pode ser definida tanto em termos da extensão dos objetos percebidos - processo de apreensão -, quanto em termos de intensidade da percepção - processo de focalização. Assim, na apreensão, intensidade e extensidade se desenvolvem de maneira conversa: quanto maior o número de objetos apreendidos, maior a intensidade da percepção. Na focalização, no entanto, intensidade e extensidade evoluem de maneira inversa, sendo que o sujeito deve selecionar onde deverá exercer sua percepção mais intensa, renunciando ao número de objetos passíveis de serem percebidos. Ou seja, na focalização, quanto menos objetos são percebidos, mais acuradamente estes são focalizados.

Ainda sobre apreensão e foco, Fontanille (2007, pg.104) nos diz que tais processos seriam regulados por actantes posicionais. Desse modo, seriam três os papéis posicionais de tais actantes: fonte, alvo e controle. Fonte seria o ponto de onde o foco ou a apreensão emana; alvo, a direção do foco ou apreensão; e controle seria a regulagem entre a fonte e o alvo. Segundo Fontanille (2007, pg.160):

Os atos perceptivos elementares (foco e apreensão) apresentam duas propriedades de base: uma direção (fonte $\rightarrow$ alvo) e um controle dessa direção, que pode modificar sua orientação, desdobrá-la, interrompê-la, prolongá-la etc. Em semiótica visual, esse dispositivo actancial aplica-se mais particularmente à iluminação, que requer fontes, alvos e que encontra, por vezes, obstáculos.

Foi a partir da última frase dessa citação que começamos a pensar a análise de Maciste no inferno (raconto) sob o ponto de vista da percepção. Como brevemente comentado anteriormente, a luz exerce um papel fundamental na 
história em questão. Pelo espaço em que se narra a trama se tratar de um cinema, a luz - ou a falta dela - permeará o percurso inteiro do sujeito.

Assim, no início do conto, temos a seguinte frase (XAVIER, 2002, pg.95):

Negro como o inferno até acostumar a vista fico em pé as mãos na mureta de madeira que separa as fileiras de cadeiras da grande porta com cortina de velludo que separa a salla de exibições da sala de espera. ${ }^{22}$

A (falta de) luz, portanto, já se apresenta como um obstáculo a ser transposto - o sujeito deve acostumar a vista à escuridão. A narrativa prossegue e, a esse ponto, a luz da tela atua como adjuvante na busca da mulher pelo sujeito (XAVIER, 2002, p.95):

"Com a luz que vem da tella busco com os olhos aquilo que quero $(\ldots)$ "

Pensando nos actantes posicionais dos processos de foco e apreensão, a luz funcionaria como actante de controle entre a fonte (sujeito) e seu alvo (mulher). A luz não é o único actante de controle que aparecerá no texto. Percebe-se também que a própria tela do cinema também regula a relação entre fonte e alvo - sempre que o sujeito inicia seu contato com a mulher, ao perceber o risco de ser desmascarado, recorre à tela do cinema, dissimulando suas intenções (XAVIER, 2002: 111):

\footnotetext{
${ }^{22}$ Ortografia e pontuação originais foram mantidas.
} 
Ouso, empurro meus dedos trêmulos e toco seu braço como se fosse sem querer Não sobre a cadeira ao lado meu chapeu esta assentado sobre meu sexo agora zona de calor Ella afasta seu braço vira-se e olha firme para mim meus olhos estão na tella

Um terceiro e último actante de controle seria a blusa de seda que a mulher veste. Por diversas vezes, o sujeito citará a referida blusa como um obstáculo - por ela ser folgada, por mais que o homem encoste seus dedos nela, esta não permite que se toque o corpo da mulher (XAVIER, 2002: 107):

É bella e macia, estou com meus braços cruzados e as pontas dos meus dedos acariciam o fino tecido de sua blusa solta ella não solta os olhos da tella cintilante nem sente minha caricia na seda macia (...)

Tendo definidos os actantes posicionais (fonte: sujeito; alvo: mulher; controle: luz, tela do cinema e blusa de seda), cabe-nos sistematizar o campo de presença do sujeito por meio dos processos de focalização e apreensão. Maciste no inferno (raconto) tem início com o sujeito lendo as próximas atrações do cinema (XAVIER, 2002, p.83):

Noite de Amor...

Vertigem de Luxo...

Caminho da Perdição...

Gigolô...

Rouge e Pó de Arroz...

Perdida em Paris...

Os Mysterios de Hollywood...

Bachanal...

Sodoma e Gomorra...

Três noites de D. Juan...

Macho e Femea...

Maciste no Inferno... 
Nesse momento, apreensão e foco estão átonos, o que descreve um sujeito da vacuidade. Na próxima página, a apreensão se tornará tônica: há a percepção de uma grande extensão de elementos, uma mistura, numa espécie de delírio figurativo (XAVIER, 2002: 87):

Columnas, templo, quadrigas, bastilhas de papelão, cavalheiros da Idade Média, D'artagnans de fancaria, annuncios, luminosos, projectores, lâmpadas, lettreiros, caretas, diálogos, versos, chronicas, commentarios, apreciações, taboletas nos bondes e nos automóveis; latagões de feira com estandarte e bandas de músicas; coxas nuas de girls macias, meninas cobras deitadas sobre areias, mulheres velludo em atitudes lascivas sobre leitos ou dentro de alcovas, mãos que agarram, lábios que procuram, fêmeas que se entregam, corpos em crispações, oscullos infinitos, desejos, ancias, frêmitos, espasmos...

A partir do momento em que o sujeito entra na sala de exibição, a busca por um objeto específico tem seu início. O sujeito empreende, então, o processo de focalização, numa espécie de triagem dos elementos de seu campo de presença até que o objeto buscado, a mulher, é revelado (XAVIER, 2002,p.95):

Com a luz que vem da tella busco com os olhos aquilo que quero e busco meu logar a mulher Até me assegurar que é uma mulher fico atraz da mureta de madeira as mãos segurando as bordas Para que os outros espectadores não se apercebam das minhas intenções finjo entrar na fileira de traz com mais gente; mudo de idéia e entro na fileira da frente ameaço sentar numa cadeira vazia mas sento-me ao lado della É uma mulher

Percebe-se, então, como se fosse um movimento de câmera: os olhos do sujeito percorrem a sala, encontram o que acreditam ser o que buscavam, aproximando-se, lentamente, de seu alvo até que o objeto buscado, a mulher, seja 
confirmado e verificado. A partir daí, a apreensão segue-se átona e a focalização, tônica. Aos poucos, o sujeito empreenderá o reconhecimento gradual de seu objetoalvo. A percepção da mulher torna-se intensa, levando o sujeito ao êxtase exatamente quando o seu reconhecimento se torna mais completo - quando seu dedo, finalmente, toca o seio da mulher.

Interessante notar que o gozo, ou seja, o momento de conjunção total do sujeito com o seu objeto de valor (o prazer sexual figurativizado pela mulher), se faz por meio do toque. A respeito de como o tato pode exprimir esse momento de intimidade máxima entre sujeito e objeto, podemos recorrer a uma reflexão de Greimas em Da imperfeição (2002, p. 35-36):

Pois o tato é algo a mais do que a estética clássica dispõe-se a nele reconhecer -- sua capacidade para explorar o espaço e levar em conta os volumes: $o$ tato se situa entre as ordens sensoriais mais profundas, ele exprime proxemicamente a intimidade optimal e manifesta, sobre o plano cognitivo, a vontade de conjunção total. A visualidade de Calvino, prolongando-se assim, desce delicadamente alguns graus em direção ao toque, forma figurativa da conjunção.

Após o gozo, o processo de focalização é cessado, retornando o sujeito ao estado de vacuidade, dotado de apreensão e focalização átonas. O sujeito sai do cinema e a narrativa se encerra. 


\subsection{Considerações finais}

A partir do conceito de mistura, pudemos, inicialmente, descrever parte do estilo de Valêncio Xavier - caracterizado, principalmente, pelo sincretismo de linguagens. Em seguida, por meio de uma breve explanação da narrativa de Maciste no inferno, empreendemos uma análise sob o ponto de vista da percepção.

Assim, resumidamente, Maciste no inferno teria como temática a perversão de um sujeito qualquer pela satisfação sexual casual em cinemas. Tendo como pano de fundo o filme italiano, de 1926, Maciste all'inferno, a narrativa se encaminha de modo a mostrar o programa do sujeito em busca de uma mulher capaz de satisfazer seu desejo sexual.

Por um processo de focalização, o sujeito seleciona seu objeto-alvo, a mulher, colocando em prática o seu programa narrativo: o de entrar em conjunção com a satisfação sexual. A esse momento, poderíamos dizer que estamos diante de um fazer emissivo, continuativo. O momento do gozo, no entanto, coincide com o momento em que o sujeito é surpreendido pela repressão da mulher. Ou seja, a mulher estabelece uma parada do programa - é o advento de um fazer remissivo. A partir daí, atordoado, o sujeito se retira da sala de projeção e seu programa narrativo se torna completo.

Identificamos, também, os actantes posicionais presentes na narrativa: a fonte, o sujeito; o alvo: a mulher; e o controle: luz, tela do cinema e blusa de seda. Na medida do possível, tentamos também demonstrar como elementos gráficos do texto (a utilização de duas fontes diferentes; o verso cinza das páginas; os fotogramas etc.) contribuíam para seu processo de significação. 
Sendo nossa análise apenas um dos recortes possíveis de se fazer, temos certeza de que Maciste no inferno renderia ainda muitas outras análises diferentes, como por exemplo, um estudo mais específico a respeito da relação entre a narrativa que se passa no filme e a narrativa que se passa no cinema.

Esperamos, no entanto, que nossa análise tenha sido acertada ao menos àquilo a que ela se propunha. 


\section{CONCLUSÃO}

Nosso trabalhou consistiu em discutir o conceito de missividade introduzido por Claude Zilberberg e seu posterior desenvolvimento na semiótica tensiva. Para isso, dividimos nossa discussão em três partes, uma dedicada a situar o fazer missivo no conceito de geratividade e transvalorização, outra cercando o próprio conceito de missividade e, por fim, uma parte dedicada a apontar similaridades e diferenças entre a missividade e a noção conceitual de acontecimento.

Esse primeiro momento mais "teórico" de nosso trabalho se baseou principalmente em três textos-base: "Pour introduire le faire missif' (1986), publicado na revista RSSI; o capítulo homônimo ao artigo, publicado no livro Raison et poétique dus sens (1988); e o verbete "Génératif (parcours)", contido no segundo volume do Dicionário de semiótica (1986).

A fim de demonstrar não apenas sua efetividade, mas também sua extensão no que diz respeito às possibilidades de aplicação, nossa dissertação também contou com dois capítulos de análise de dois textos literários: o poema "Ciao cadáver", de Delmo Montenegro, publicado em seu livro homônimo, Ciao cadáver, de 2005; e o livro-conto Maciste no inferno (raconto), de Valêncio Xavier, publicado em 1983.

Não podemos dizer que o caminho foi fácil. Já em nossa qualificação fomos alertados de que escolher uma discussão teórica como tema talvez fosse mais do que um mestrado exigiria. Aceitamos a observação e hoje, com o trabalho concluido, acreditamos que seu valor talvez não esteja na discussão, novidades ou reviravoltas que traz à banca - reconhecemos que para desempenhar uma discussão teórica de 
peso ainda precisamos de maturidade acadêmica que, no início de nossa pósgraduação, estamos longe de possuir - mas sim nos objetos escolhidos, tanto práticos quanto teóricos.

Acreditamos existir uma lacuna a ser preenchida no que diz respeito aos estudos da semiótica tensiva. Nós, como pesquisadores imteressados, diante mesmo de nossa escolha de tema, tivemos de recorrer a pouquíssimos textos que de fato pudessem ser usados como refência bibliográfica. Faltam-nos tanto textos fundadores, como os do próprio Claude Zilberberg ou de Jacques Fontanille, quanto materiais de discussão dos textos fundadores, tornando bastante árdua a tarefa do pesquisador interessado pelo modelo tensivo. Obviamente, o modelo tensivo é uma teoria ainda em desenvolvimento, passível de ser mudada, transformada ou reavaliada a cada texto de seus principais autores, no entanto, não podemos deixar de ter a impressão de que o que nos resta é a necessidade de confiarmos apenas em nossa leitura do modelo, o que acaba por fazer da semiótica tensiva uma teoria de muitas interpretações.

Ainda assim, com a escrita de nosso trabalho, pudemos chegar a algumas conclusões, ao menos para nós, interessantes acerca da missividade e dos textos literários analisados.

No que diz respeito ao conceito de fazer missivo, não podemos deixar de mencionar que acreditamos ser de extremo valor para a teoria tensiva. Tendo suas bases na própria tentativa de Zilberberg de redimensionar, ou reconfigurar, o percurso gerativo do sentido e de ter sido um dos poucos conceitos tensivos a ter a avaliação do fundador da semiótica francesa, A. J. Greimas, marcando presença no 
segundo volume do Dicionário de semiótica, acreditamos que o fazer missivo não recebeu ao longo dos anos atenção merecida.

Entendendo o missivo como pressuponente do nível tensivo e pressuposto do nível narrativo, muito se esclarece a respeito do movimento de transvalorização de um nível a outro do percurso gerativo do sentido. Como tensão e distensão reverbarão em, por exemplo, espera ou busca no nível discursivo é muito melhor explicado se pensarmos que tensão e espera, de um lado, e distensão e busca, de outro, podem ser manifestação de dois regimes de valores diferentes: um remissivo, de parada, limites e contenções; e outro emissivo, de parada da parada, de arroubo, movimento.

Quanto às nossas análises dos textos literários, acreditamos ter nos rendido conclusões também interessantes, expressadas em mais detalhes no subtópico "considerações finais" de cada análise. No que diz respeito ao poema "Ciao cadáver", de Delmo Montenegro, acreditamos termos aprendido a como penetrar textos aparentemente impenetráveis utilizando-nos de ferramentas teóricas, de um lado, tão simples, como a busca por isotopias e de outro tão novas, como o modelo tensivo. Da análise do livro-conto de Valêncio Xavier, Maciste no inferno (raconto), acreditamos termos tirado maior conhecimento quanto à questão da percepção, além do desafio de trabalhar com texto conjugador de tantas linguagens e recursos gráficos.

Terminamos,pois, esse trabalho aliviados pelo fim de um longo caminho de aprendizado acadêmico - e, por que não, pessoal - , gratos pela oportunidade e em espera quanto ao nosso porvir - que seja recheado de desafios! 


\section{REFERÊNCIAS BIBLIOGRÁFICAS}

ApUlEIO. O Asno de ouro. São Paulo: Cultrix, 1963

BARros, Diana L.P. Teoria do discurso - fundamentos semióticos. São Paulo: Humanitas, 2000.

. Teoria semiótica do texto. São Paulo: Ática, 2002.

Bertrand, D., Caminhos da semiótica literária. São Paulo: Edusp, 2003.

CAmpos, Haroldo de. Signantia: quasi coelum. São Paulo: Perspectiva, 1979.

DICIONÁRIO Escolar Francês-Português. Rio de Janeiro: MEC, 1972

DICIONÁRIO Houaiss da Língua Portuguesa. Rio de Janeiro: Objetiva, 2001

DıcıonÁRıO de Mitologia Grego-Romana. São Paulo: Abril Cultural, 1973

FIORIN, J.L., As astúcias da enunciação. São Paulo: Ática, 2002.

. Elementos de análise do discurso. São Paulo: Contexto, 2004.

(org.). Elementos de linguística l: objetos teóricos. São Paulo: Contexto,

2003.

(org.). Elementos de linguística II: princípios de análise. São Paulo:

Contexto, 2003.

Floch, J.-M., Petites mythologies de l'œil et de l'esprit - pour une sémiotique plastique. Paris: Hades-Benjamins, 1995

, Identités visuelles. Paris: Presses Universitaires de France, 1995 
, Sémiotique, Marketing et communication - sous les signes, les stratégies.

Paris: Presses Universitaires de France, 1990

FontANILLE, J. Semiótica do discurso. São Paulo: Contexto, 2007.

Fontanille, J. \& ZIllberberg, C., Tensão e significação. São Paulo: Discurso Editorial/Humanitas, 2001.

GREIMAS, A.J., Semântica estrutural. São Paulo: Cultrix, 1976.

GREIMAS, A.J., Semiótica do discurso científico. Da modalidade. São Paulo: DIFEL, 1976.

GREIMAS, A.J., Sobre o sentido. Rio de Janeiro: Vozes, 1975.

GreimAS, A. J. \& CouRTÉS, J. Dicionário de semiótica. São Paulo: Cultrix, s/d [1983] Sémiotique. Dictionnaire raisonné de la théorie du langage, II.Paris: Hachette, 1986.

Greimas, A. J. \& Fontanille, J. Semiótica das paixões. São Paulo: Ática, 1993.

Hemingway, E. The sun also rises. New York: Simon \& Schuster, 2006.

HJeLMSLEV, L. Ensaios linguísticos. São Paulo: Perspectiva, 1991 . Prolegômenos a uma teoria da linguagem. São Paulo: Perspectiva, 1975. . Le langage. Paris: Minuit, 1966.

Montenegro, Delmo. Ciao cadáver. São Paulo: Landy Editora, 2005. 
OliveirA, A. C. de (org.). Semiótica plástica. São Paulo: Hacker, 2004.

TATIT, L. Análise semiótica através das letras. São Paulo: Ateliê Editorial, 2002. . Musicando a semiótica. São Paulo: Annablume, 1997.

XavieR, Valêncio. O mez da grippe e outros livros. São Paulo: Companhia das Letras, 1998.

ZILBeRBERG, C. "Louvando o acontecimento" in: Revista Galáxia. São Paulo, n.13, p. 13-28, 2007.

ZILBERBERG, C. "Pour introduire le faire missif" in: RSSI. Alberta, vol.06, p. 229-261, 1986.

ZILberberG, C. Razão e poética do sentido. São Paulo: Edusp, 2006a.

ZILBERBERG, C. "Síntese da gramática tensiva" in: Significação - Revista Brasileira de Semiótica, ㄲo25, junho de 2006. São Paulo: Centro de Estudos Semióticos/Annablume, 2006b. 
ANEXO

ANEXO A - MACISTE NO INFERNO (RACONTO), DE VALÊNCIO XAVIER

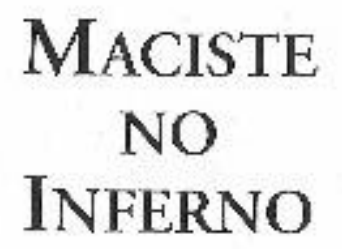

raconto

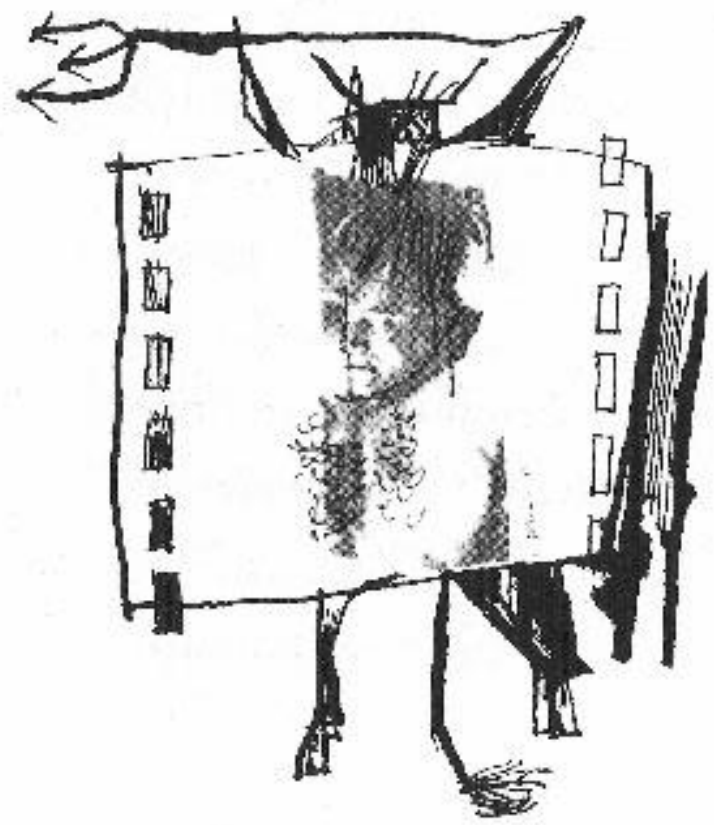


Noite de Amor..

Vertigem de Luxo...

Caminho da Perdição...

Gigolô...

Rouge e Pó de Arroz...

Perdida em Paris...

Os Mysterios de Hollywood...

Bachanal...

Sodoma e Gomorra...

Três Noites de D. Juan...

Macho e Femea...

Maciste no Inferno... 


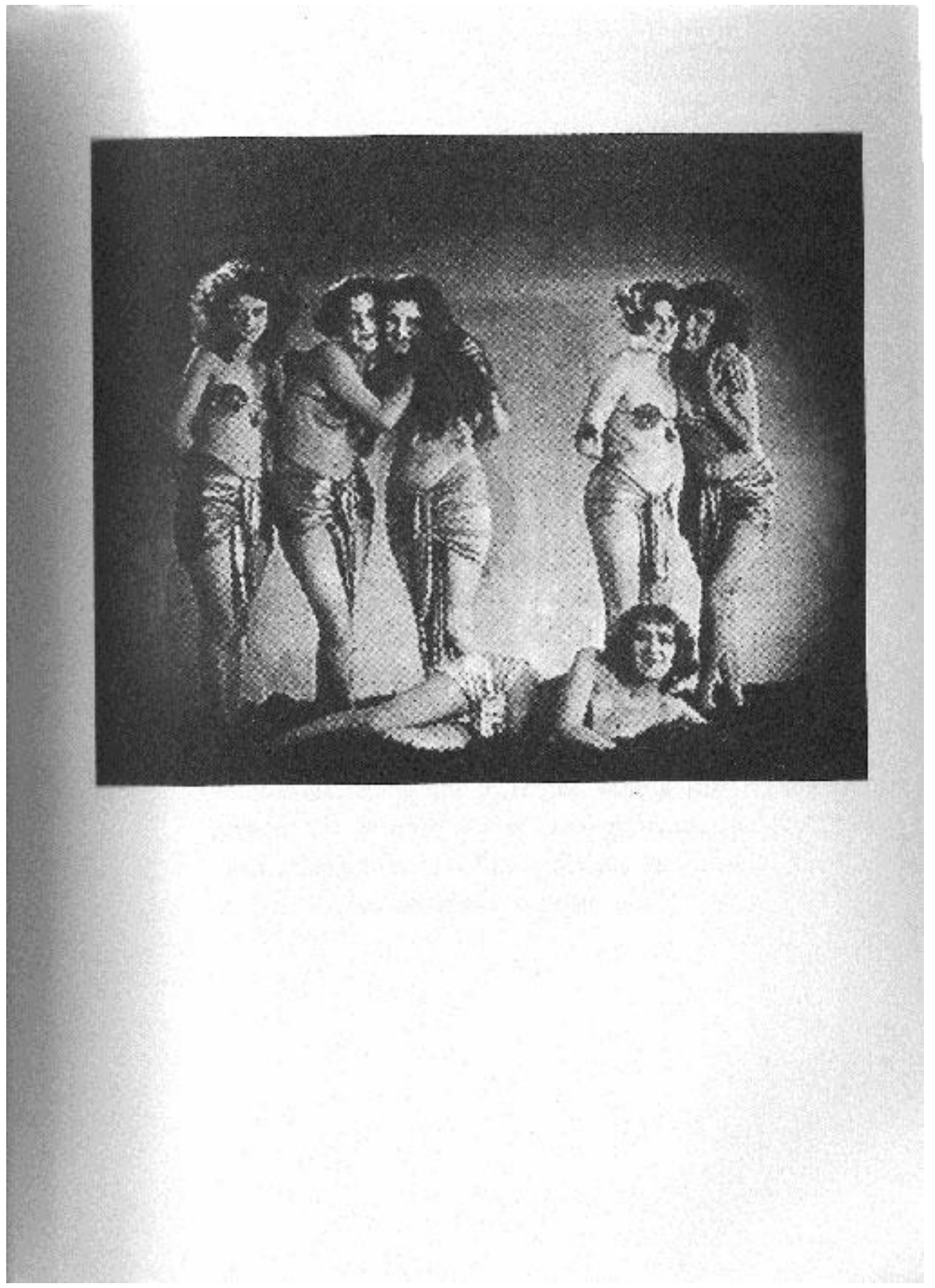


"Columnas, templo, quadrigas, bastilhas de papeláo, cavalleiros da Idade Média, D'artagnans de fancaria, annuncios luminosos, projectores, lampadas, lettreiros, caretas, diálogos, versos, chronicas, commentarios, apreciaçōes, taboletas nos bondes e nos automóveis; latagôes de feira com estandarte e bandas de músicas; coxas nuas de girls macias, meninas cobras deitadas sobre areias, mulheres velludo em atitudes lascivas sobre leitos ou dentro de alcovas, măos que agarram, lábios que procuram, femeas que se entregam, corpos em crispaçōes, oscullas infinitos, descjos, ancias, fremitos, espasmos..." 


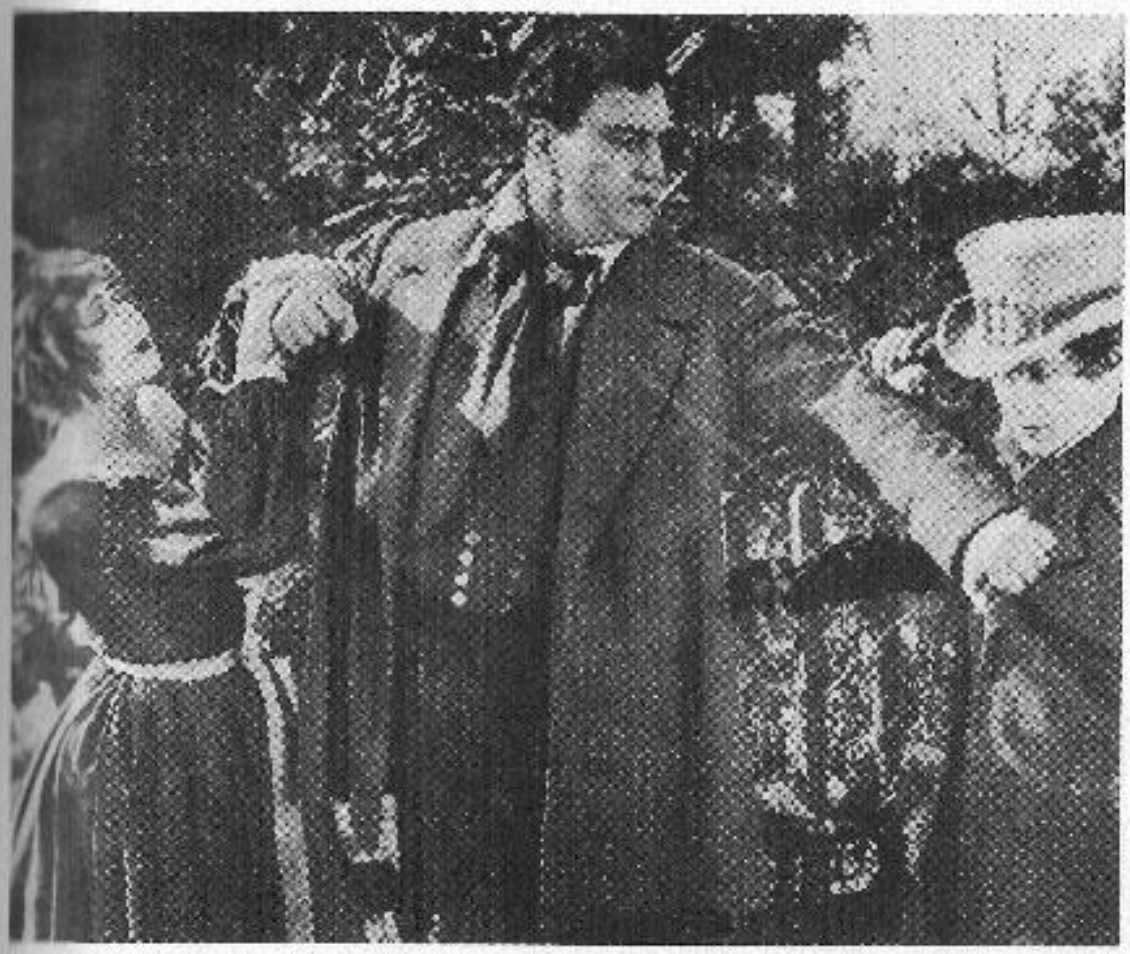


Maciste, o heroe, o homem de vigor sem egual e coraçāo generoso era tảo estimado em sua aldeia natal, onde vivia como um patadino do bem que, um belfo dia, Plutăo em seu seu reino subterrâneo de treva e rancor invejou-o e para combatel-o mandou a Terra o temônio Barbadiha, um dos seus mais ardillosos subditos, com a missão de corromper a bella Graziella, irmã de creaçāo de Maciste 

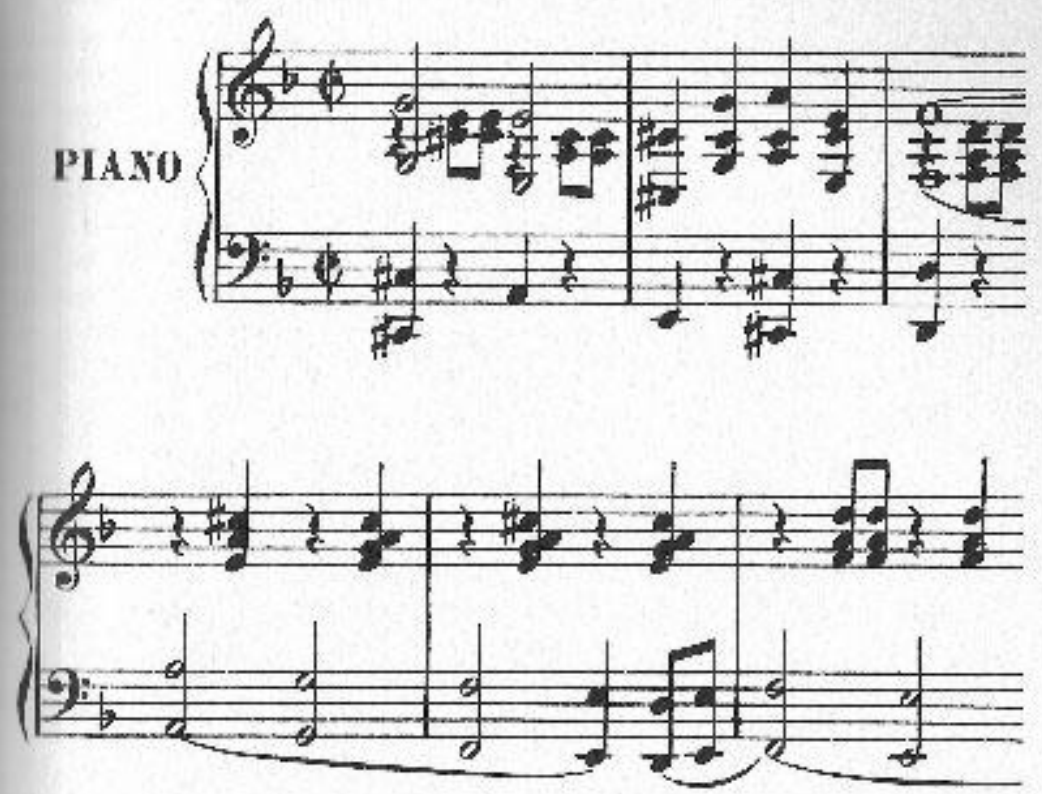
Negro como o inferno até acostumar a vista fico em pé as mấos na mureta de madeira que separa as fileiras de cadeiras da grande porta com cortinas de velludo que separa a salla de exibiçóes da salla de espera.

Este vendo Graziella seduzida por um conquistador sem escruputos percebe a intervenção de Barbaditha e, ousadamente, trava rentida fucta com o demônio que o arrasta para o inferno 


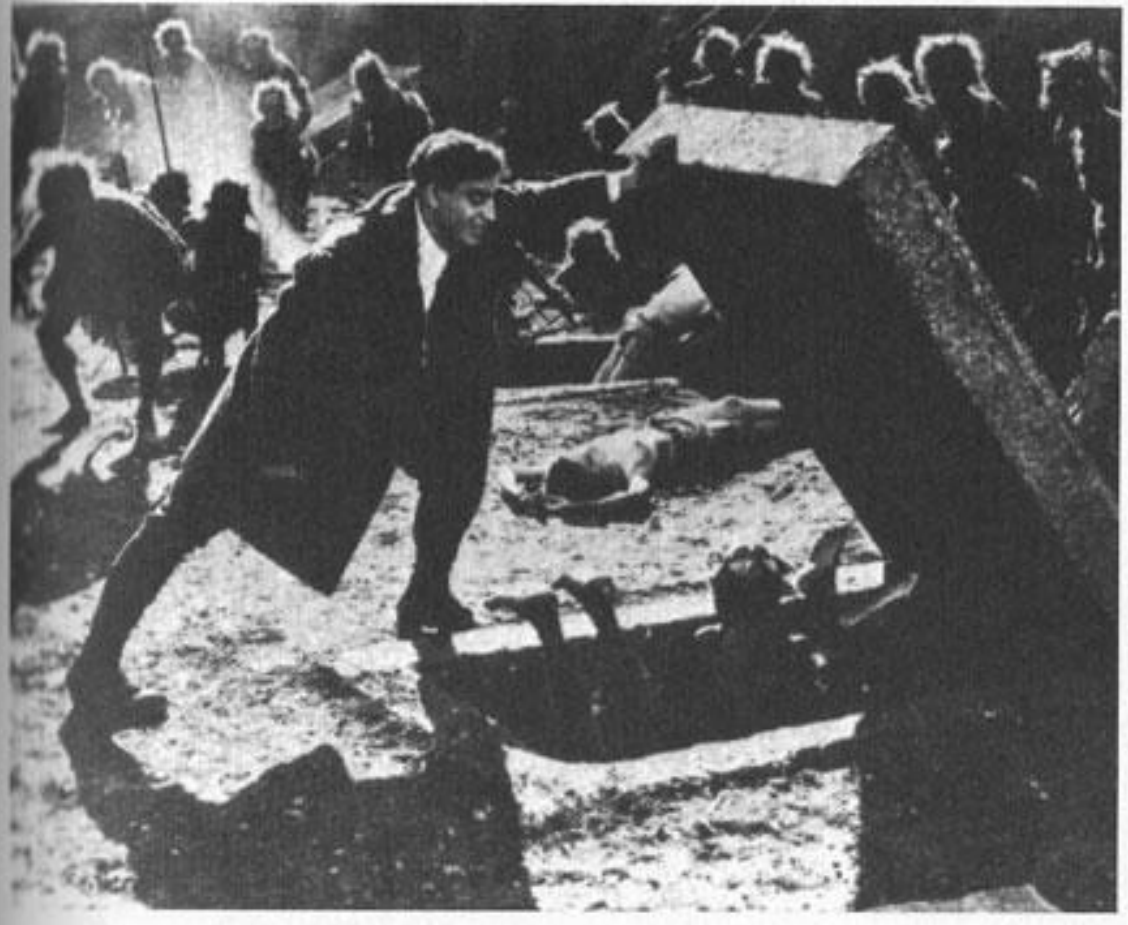


Com a luz que vem da tella busco com os olhos aquillo que quero e busco meu logar a. mulher Até me assegurar que é uma mulher fico atraz da mureta de madcira as mãos segurando suas bordas Para que os outros espectadores năo se apercebam das minhas intençōes finjo entrar na fileira de traz cotn mais gente; muclo de idéia e entro na filcira da frente ameaço sentar numa cadeira vazia mas sento-me ao lado della E uma mulher 


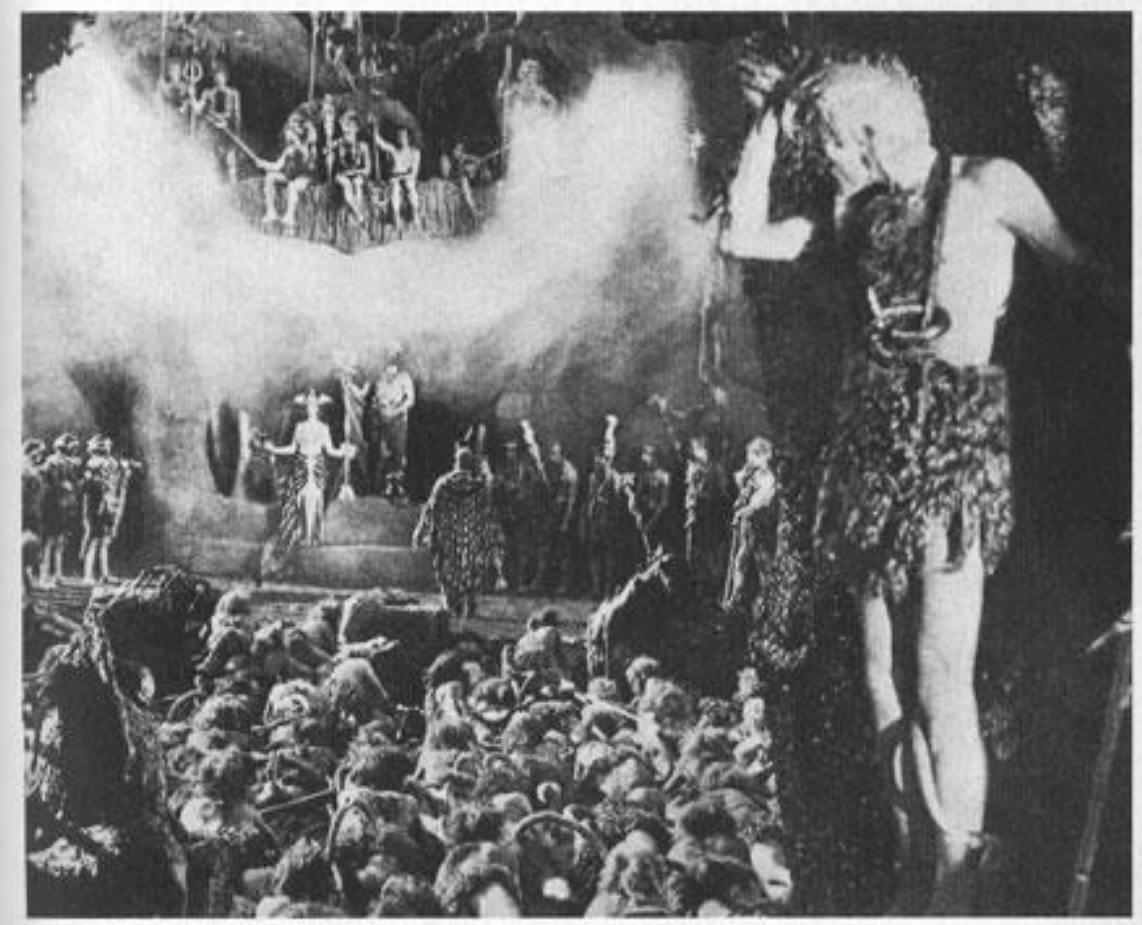


Ê uma mulher Fingindo attençăo na tella com o rabo dos olhos olho com coragen viro um pouco, bem pouco, a cabeça para que ella não perceba que estou olhando a clla Nem tentei encostar meu braço no seu e ella olha a tella tremeluz 


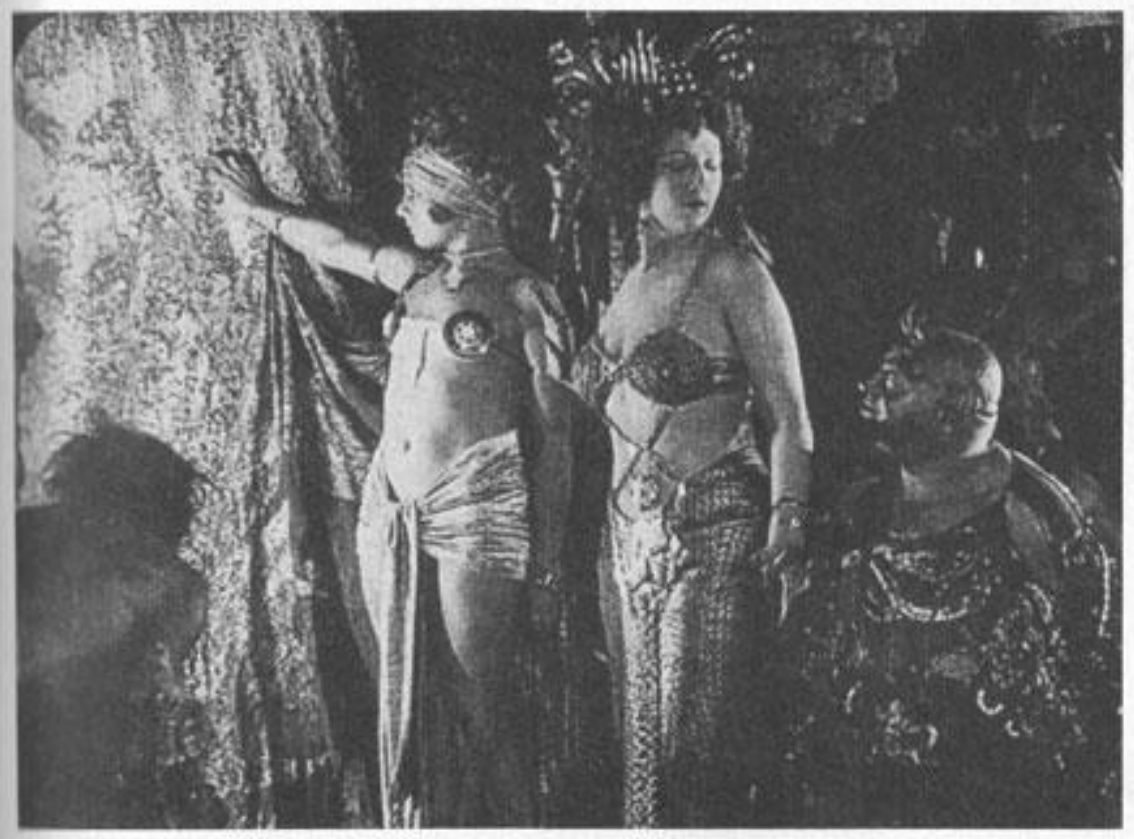


Ora o mortal que chega ao inferno sem ter morrido, pode voltar ao mundo se ao fim de trez dias não tiver cedido à tentação de alguma beldade d'aquelle antro

É bella e macia, estou com meus braços cruzados e as pontas dos meus dedos acariciam o fino tecido de sua blusa solta ella não solta os olhos da tella cintilante nem sente minha caricia na seda macia diferente do áspero velludo das vermelhas cortinas É um filme marron nas cennas de inferno é vermelho Um calor me sobe por todo meu corpo, frieza da seda

Ora, Proserpina, a esposa própria de Plutão tenta-o com encantos taes que Maciste ousa beijal-a: Estava decretada sua sentença às pennas etternaes 


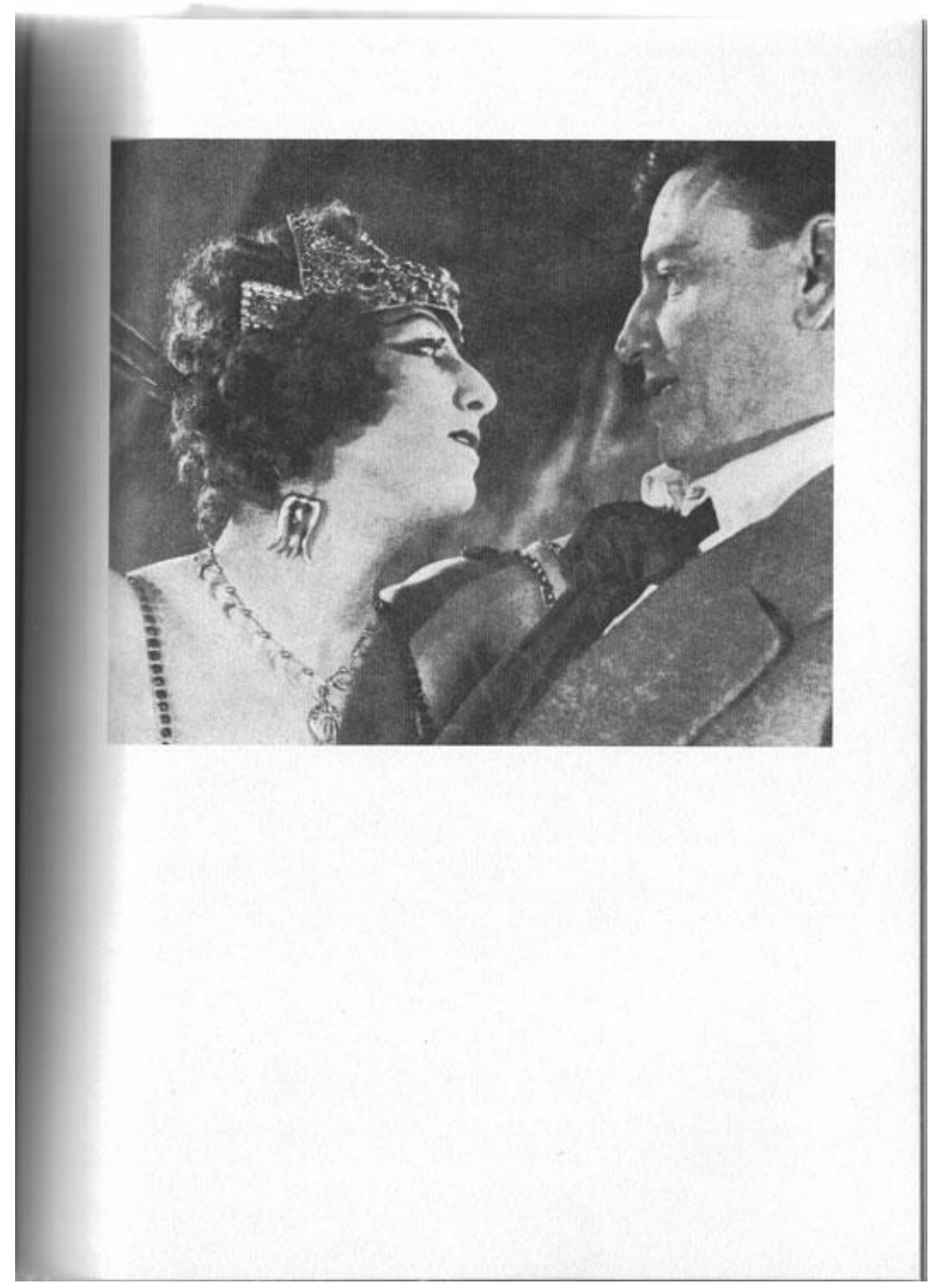


Ouso, empurro meus dedos tremulos e toco seu braço como se fosse sem querer Não sobre a cadeira ao lado meu chapeu esta assentado sobre meu sexo agora zona de calor Ella afasta seu braço Ouso, insisto ella afasta seu braço vira-se e olha firme para mim meus olhos estão na tella 


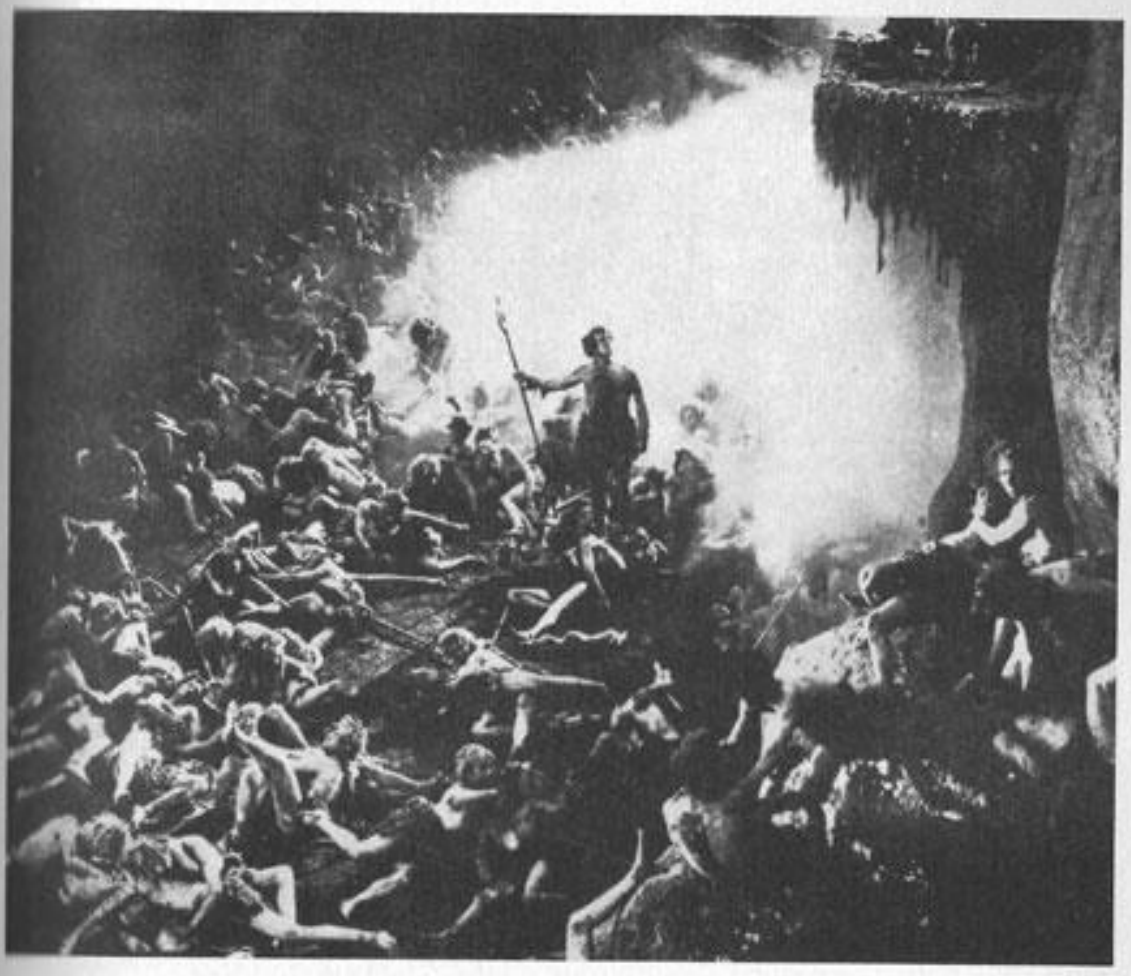


Entrectanto Barbadilha, ardiloso e revoltoso, quer a todo transe desthronar Plutão, para tanto architeta uma revolução no inferno.

Somente por sua lealdade instinctiva, Maciste poem sua força e destreza sem egual ao serviço de Plutão e consegue debellar a revolução e castigar o pérfido Barbadilha

Acaricio o fino tecido e os dedos vão se aproximando vagarosamente Como os braços della estão bem postos para traz os dedos vão chegando a parte do lado de seu seio direito, logar onde o tecido também é solto - como nas mangas da blusa - e não encosta no seio pelo menos na parte lateral Olho a tella e nada vejo Poma macio dura vejo 


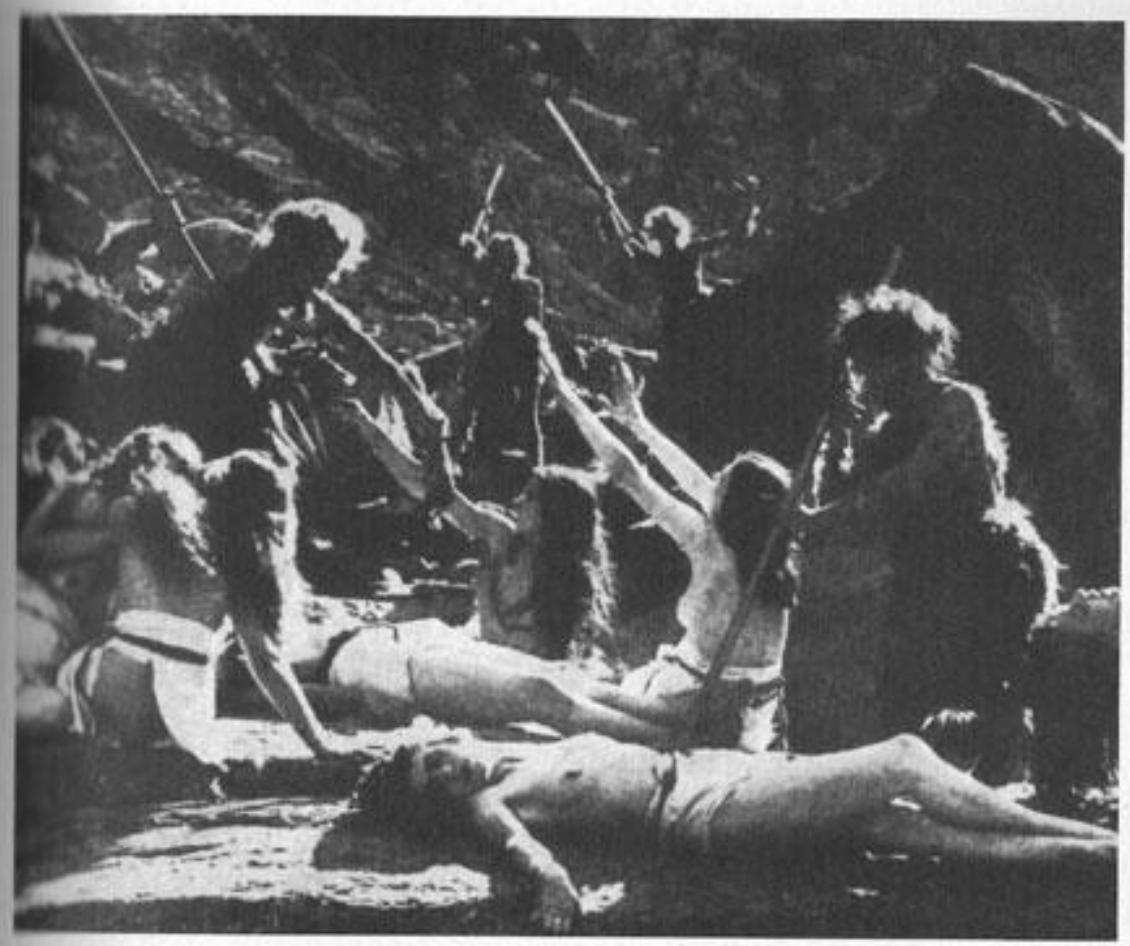




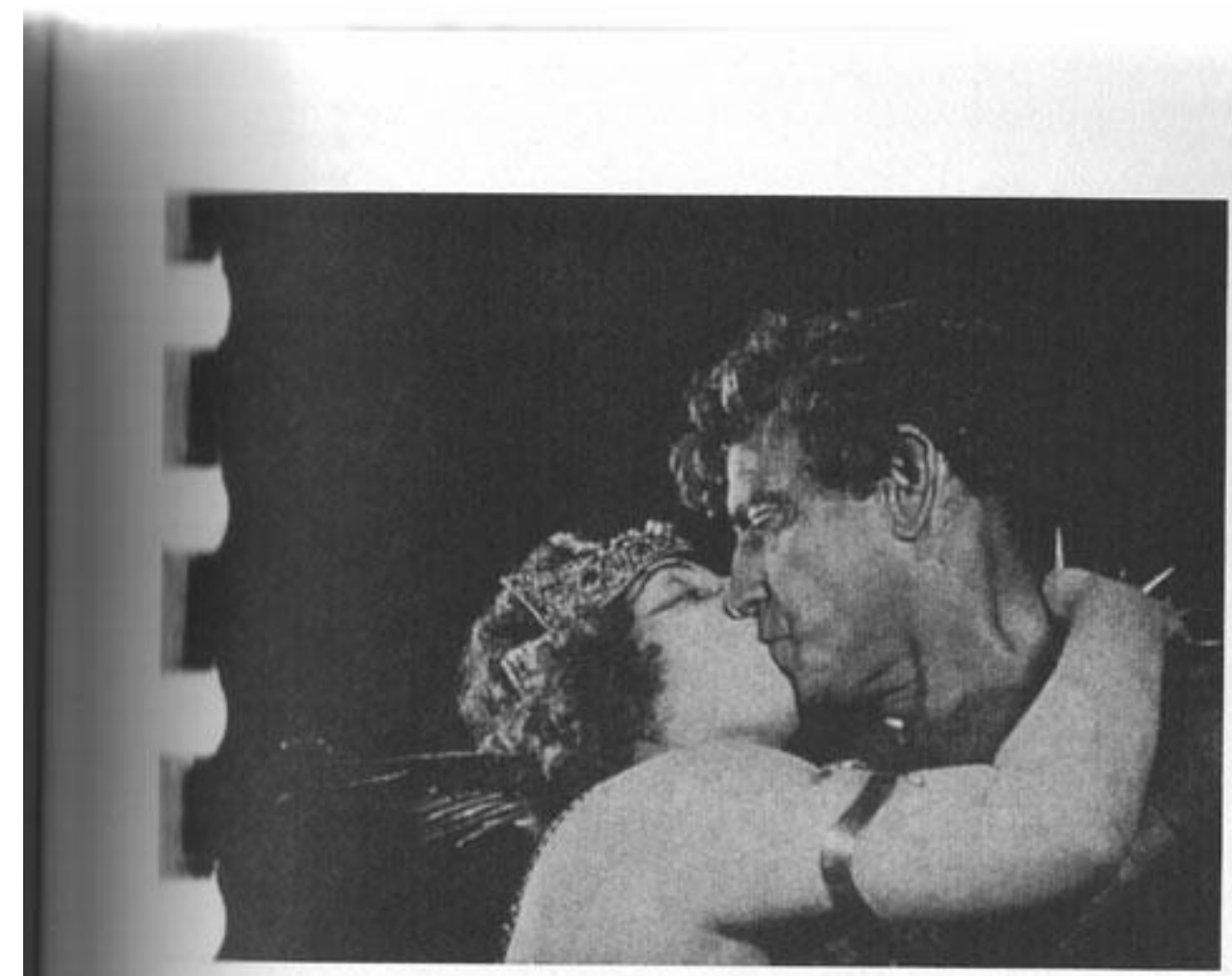


Então terminada a lucta, Plutão chama o heroe a sua ignobil presença e em lembrança aos seus serviços auctoriza-lhe a voltar a Terra: Proserpina protesta contra isso, mas em văo. Maciste prepara-se para partir, mas Proserpina arma-Ihe um laço, manda-o prender e torna a beijal-o, condemnando-o novamente à penna eterna

Latagôes com estandartes e bandas de músicas, coxas nuas de girls macias, meninas cobras deitadas sobre areias, mulheres velludos em attitudes lascivas, mãos que agarram tóco finalmente o lado de seus seios calor, lábios que procuram, femeas que se entregam, corpos em crispaçôes, oscullos infinitos, desejos, ancias, fremitos, espasmos... No espasmo do gôzo nem sinto suas unhas vermelhas fincarem-se em minha carne:

"Que é isso? se o senhor não ficar quieto eu chamo o guarda!" 


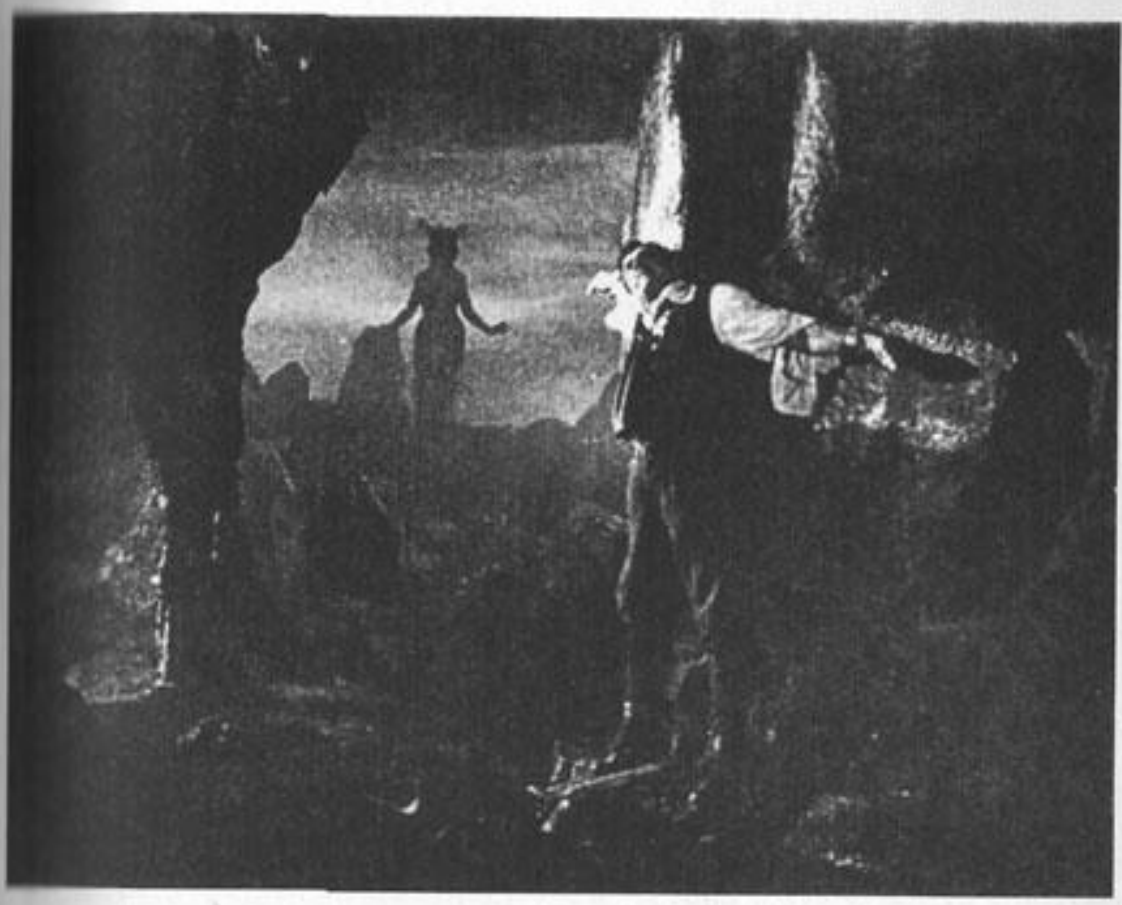


Levanto sem olhar saindo pelo outro lado das cadeiras Disfarço sair agora sem o filme acabar chamaria atenção; por isso dirijo-me ao banheiro Letreiros homens pintado num vidro que a luz vermelha alumia Uma pequena cortina vermelha antes da porta impede que abrindo a porta a meia luz do logar chegue na salla de projeção Evito olhar no espelho não há toalha limpo a mim e a calça como posso com o papel do programa que anuncia as próximas fitas Caminho da Perdição... As Trez Noites de D. Juan... Macho e Femea... Sodoma e Gomorra...

Entrectanto, na Terra, o seductor de Graziella arrependido de seu acto, volta para junto d'ella e seu filho, que já tem então um anno e meio de edade. Na véspera do Natal, 


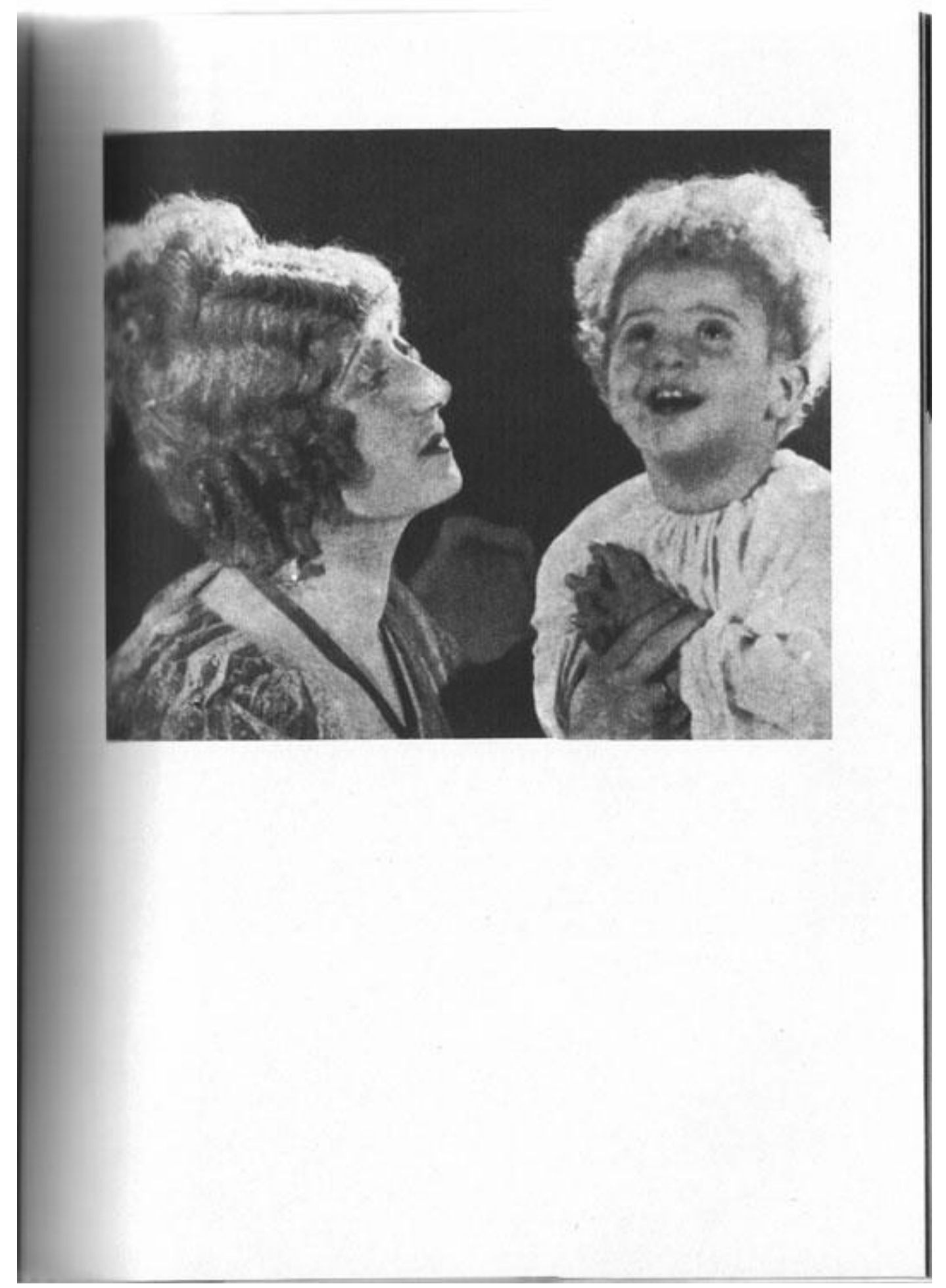


Graziella faz esta adorável creança rezar por seu protector, o impávido collosso Maciste e dá-se o milagre: a prece infantil é ouvida e o Todo Poderoso liberta Maciste e este volta à Terra para gozar a ventura de um novo lar, entre seus amigos

Não posso ficar neste logar muito tempo chamaria a attenção sobre minha pessoa A fita está acabando apresso-me com o chapeu cubro a mancha úmida de minha calça as gentes da salla de espera me olham sou

o primeiro a sair 


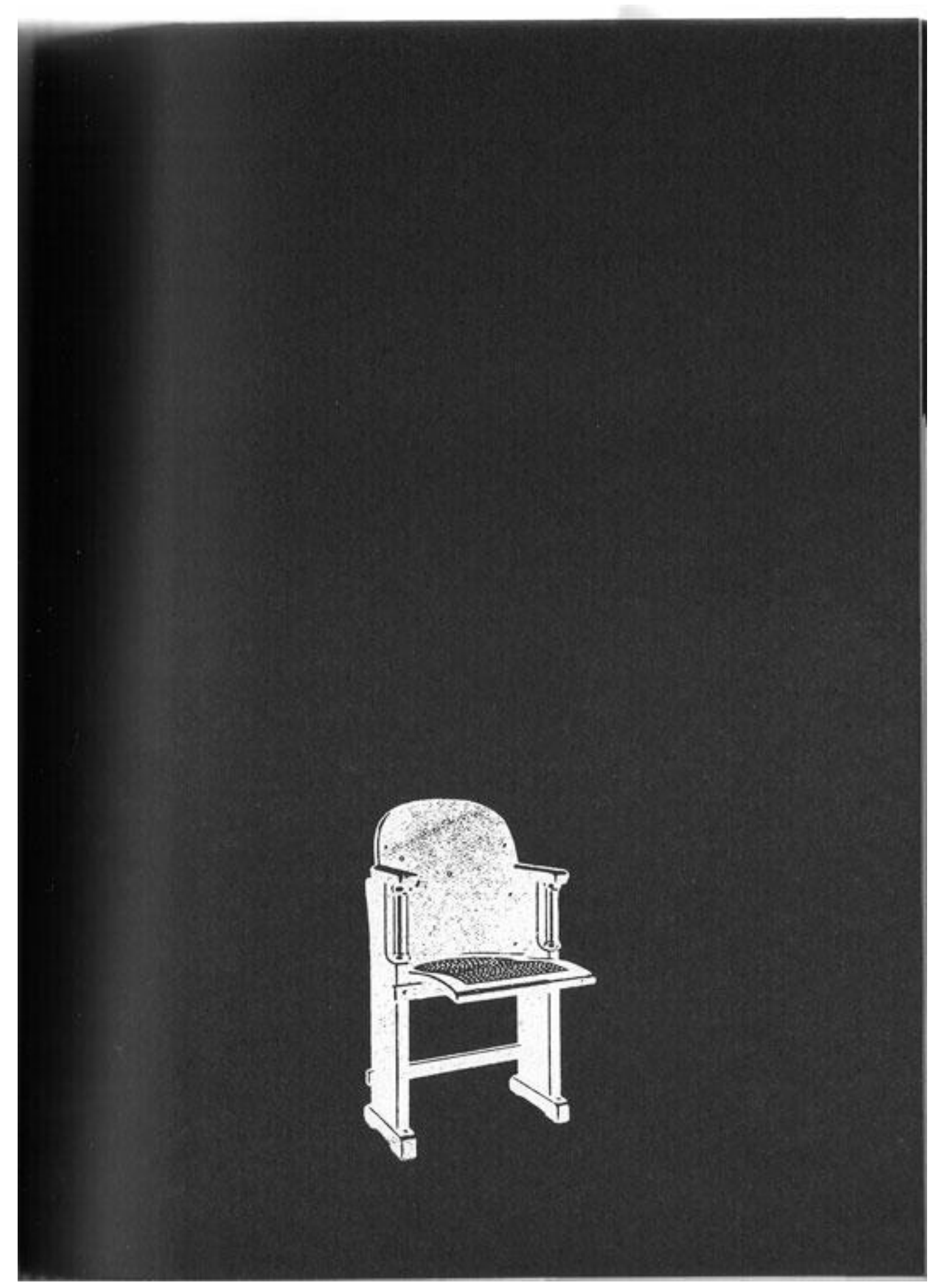


Mesmo a luz mortiça das quatro horas da tarde me cega Já não escuto o piano quando todos começam a sair da sessão já estou escutando o barulho da cidade das casas das vozes dos automóveis dos ruidos

Sou novamente parte da cidade e ninguém me vê 


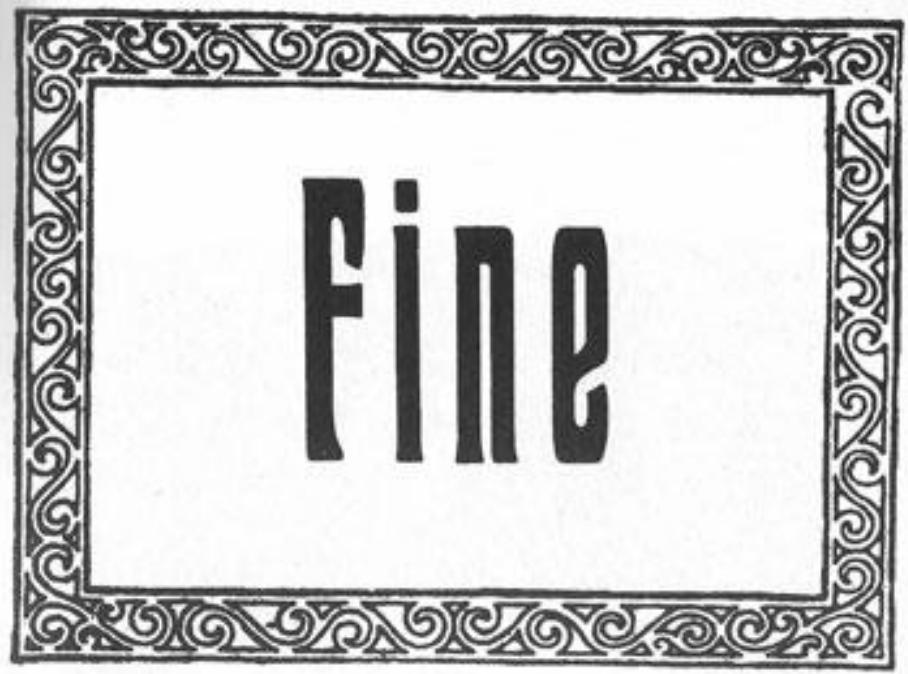

